\title{
THE NOISE OF SILENCE HOW SUPPRESSION OF FREE EXPRESSION THREATENS THE FRAGILE PEACE IN POST-GENOCIDE RWANDA
}

\author{
by \\ Ato Kwamena Dadzie \\ A thesis submitted to the Faculty of Graduate and Postdoctoral Affairs in partial fulfillment \\ of the requirements for the degree of Master of Journalism \\ Carleton University \\ Ottawa, Ontario
}

Supervisor: Klaus Pohle

(C) 2014, Ato Kwamena Dadzie 


\begin{abstract}
As Rwandans commemorate the $20^{\text {th }}$ anniversary of the 1994 genocide, the world's attention has been focused on how the country has managed to recover from that traumatic episode. But this thesis argues that the restrictions on free speech and press freedom is a symptom of a serious malaise in Rwanda's political system; the malaise of authoritarianism, borne out of the flawed transition after the genocide.
\end{abstract}

These transitional flaws made it possible for the post-genocide regime to impose its will on the country with little or no public deliberation, creating an enforced peace under which Rwanda's two main ethnic groups look upon each other with as much suspicion as they did before the genocide. This is the very authoritarian and sectarian malaise that culminated in the genocide in 1994.

The argument is made here that Rwanda faces the serious risk of another violent conflict if the flaws of the transition are not corrected to bring about a toleration of dissent and criticism on the part of government. It also entails the removal of the country's media instruments from the control and manipulation of the state.

Correcting the flaws of the transitional process should begin with the international community shedding the guilt of its failure to prevent the genocide, demanding the regime's commitment to greater respect for fundamental civil and political rights (including freedom of expression and press freedom) in return for economic support. It also requires an end to the rather condescending notion that Rwandan's deserve nothing better than an authoritarian government which secures peace and keeps the economy on the right footing by use of, among other things, draconian laws against the media and free expression. 


\section{Acknowledgements}

I wish to thank the staff and faculty of Carleton University's School of Journalism and Communication for all their support, without which this project would not have been possible.

Special thanks to my supervisor, Prof. Klaus Pohle. Thanks so much, sir, for your patient guidance and good humour.

I would also like to mention professors Susan Harada, Kirsten Kozolanka, Chris Waddel and Allan Thompson for their support and encouragement. I can't leave out Cindy Kardash-Lalonde, my boss at the Readers Digest Resource Centre, for being so accommodating.

Off campus, I also received a lot of support and encouragement from several friends. $\mathrm{H}$. Kwasi Prempeh of Seton Hall University Law School led me to a great deal of useful journal articles; Angélique Wojcik-Simpson and Phillip Nyakpo provided crucial advice.

Heartfelt gratitude goes as well to Carleton University's Faculty of Graduate and Postdoctoral Affairs, the estate Eleanore Roberta Powell (for the Robert and Alyce Martin Scholarship) and to the trustees of the Richard J. Van Noon Scholarship for the generous funding, without which this station in my life's journey would have been quite miserable.

To Nana Ama Agyeman Asante, Christine Agamah, Ben Peterson (Newsana), Rachel Pulfer (Journalists for Human Rights), Michael Cooke (Toronto Star), Alexandra Tomescu, Mike Farrinaccio, Elikem Deku, Keith Goddard, Lianrui Jia and Eyram Kuivi, I can only say I couldn't have done this without you. Each of you has been a strong pillar of support on this project and in many other diverse ways. 


\section{Dedication}

Dedicated to my uncle, Emmanuel Kwadwo Anim-Otchere - for my first chalk board, for holding my hand to the starting point of my educational career and for making sure I stayed in school in spite of all the privations. There are no words worthy enough to show my gratitude. 


\section{TABLE OF CONTENTS}

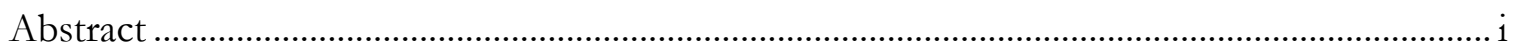

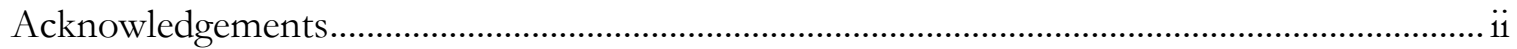

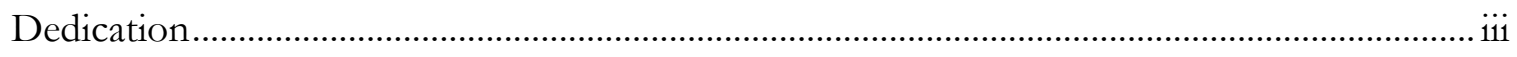

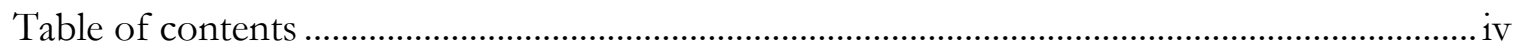

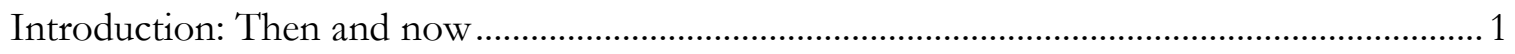

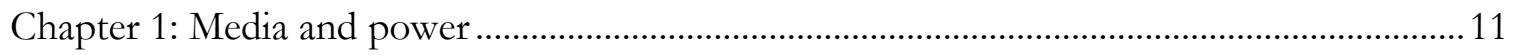

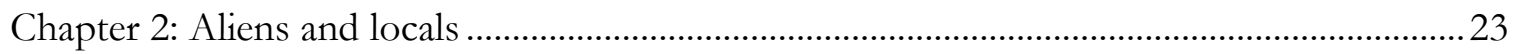

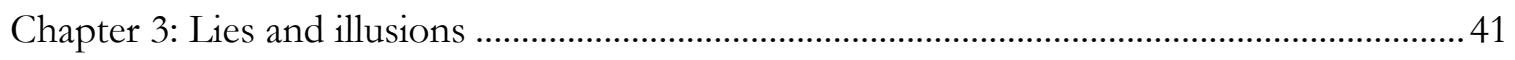

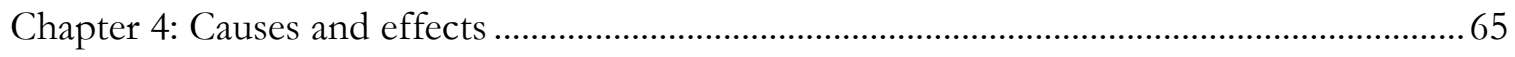

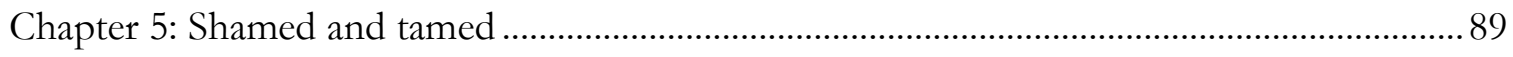

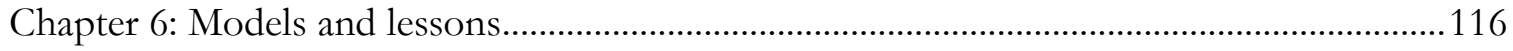

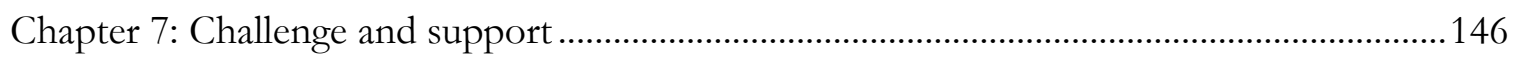

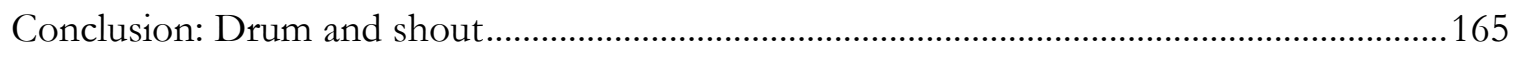

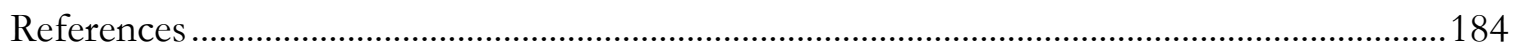


Introduction

\section{THEN AND NOW}

About 20 years ago, Rwanda was literally on its knees, drenched in blood and tears. Its institutions were broken, much of the population displaced, most on the run as refugees. Terrified and traumatized, they sought refuge in shacks and tents in areas both within the country and just outside its borders. Terror reigned and the only commodities in abundant supply were hopelessness and despair.

In the eyes of the world, a civil war had ended and the victorious guerrilla army was scrambling to form a government even as it came to terms with a human tragedy that had been wrought by the ousted regime as it desperately fought to hang on to power. The world looked on in shock as evidence of the tragedy was repeatedly splashed on newspaper front pages and television screens - hundreds of thousands of corpses littering the streets, buried in mass graves or floating on rivers, stacked in heaps in schools, churches and hospitals. One of the worst human tragedies of the $20^{\text {th }}$ century had occurred in one of the smallest nations on the African continent. The deputy commander of the hapless United Nations Peacekeeping Force in Rwanda at the time, Henry Anyidoho, vividly described the scenes in Rwanda as the tragedy unfolded:

The militias went on the rampage and massacred in the hundreds, and killed in the thousands. Mutilated human bodies, the charred shapes of dogs and cows, littered the streets as the ravenous dogs dragged dead bodies from one side of the road to the other, until the flesh peeled from the bones. The sight of carnage and the wanton destruction so dazed our senses and confounded our thinking that in order to stand firm and continue our operation, we had to pretend the peril was not present (Anyidoho, 1997, pp. 36-37).

Anyidoho's boss, the Canadian army general, Romeo Dallaire, made impassioned pleas to UN headquarters for a more robust mandate to authorize him to intervene to stop the carnage. He was ordered to stay neutral, leaving him and his force with little to do but watch the disaster 
unfold. Dallaire would later describe what he saw as "an unimaginable evil [that] had turned Rwanda's gentle green valleys and mist-capped hills into a stinking nightmare of rotten corpses" (Dallaire, 2003, p.1).

That "unimaginable evil" had a name: genocide. It was a crime against humanity, defined in international law as any number of acts "committed with intent to destroy, in whole or in part, a national, ethnical, racial or religious group." Such acts include "killing members of the group; causing serious bodily or mental harm to members of the group; deliberately inflicting on the group conditions of life calculated to bring about its physical destruction in whole or in part; imposing measures intended to prevent births within the group [and] forcibly transferring children of the group to another group" (United Nations General Assembly, 1948, December 9).

As a crime, it had an antecedent in what Adolf Hitler's regime set out to do with the Jews in the first half of the $20^{\text {th }}$ century and, even though the Rwandan genocide claimed fewer lives than the holocaust, the genocidal murderers in Rwanda killed with a sort of macabre efficiency that would make even the Nazis look back and see themselves as laggards. Samantha Power describes it as "the fastest, most efficient killing spree of the twentieth century" (Power, 2001). And as Gourevitch puts it:

Take the best estimate: eight hundred thousand killed in a hundred days. That's three hundred and thirty-three and a third murders an hour - or five and a half lives terminated every minute (Gourevitch, 1999, p. 133).

With so many lives lost in such a short period, world leaders, academics and ordinary citizens across the globe have since been left wondering how the world could have looked on and let such a catastrophe happen. The answers to that question have been numerous and varied, but with little consensus. 
However, one thing is certain today. Looking at Rwanda in 2014, it is hard to imagine that it is the same country that was thrust onto the world agenda by stark images of rotten corpses, masses of desperate and traumatised refugees carrying mattresses and goats, not to mention those sickly-looking children playing with skulls and bones. Two decades after the genocide of 1994, Gettleman could describe Rwanda as "one of the safest places I've been this side of Zurich." The country is reputed to be one of the cleanest in Africa (Gettleman, 2013, Sept. 4), free of corruption and unnecessary bureaucracy (The Economist, 2012, February 25), just two of the many factors which make it one of the best investment destinations in Africa (Crisafulli and Redmond, 2012). Kinzer insists that Rwanda:

Has recovered from civil war and genocide more fully than anyone imagined possible and is united, stable and at peace. Its leaders are boundlessly ambitious. Rwandans are bubbling over with a sense of unlimited possibility. Outsiders, drawn by chance to help transform a resurgent nation, are streaming in (Kinzer, 2008, p. 2).

Rwanda has come a long way from the hopelessness and despair of 1994. It is a remarkable turnaround story which delights many observers. But the country has not fully recovered yet. As Rwandans commemorate the $20^{\text {th }}$ anniversary of the genocide, there are other voices that warn against complacency and the tendency to overlook signs that much remains to be done to promote reconciliation and national unity, vital prerequisites for ensuring that the genocide is never again repeated or even attempted. These voices fret about the governance of Rwanda, the risk and dangers inherent in the calcification of what Fareed Zakaria (1997) describes as an "illiberal democracy," in which elections are used to conceal the denial of fundamental rights and freedoms, including press freedom and freedom of speech.

In Rwanda today, limits on free expression provide more than ample ammunition for the government's critics, who come in various hues. There are few critics of the government who 
don't point to the media environment in Rwanda to make a case against the current regime. Two recent cases that captured international attention illustrate how both the government and its critics defend their position on the ability (or inability) of Rwandans to freely express themselves and how the media in their country should operate in the aftermath of the genocide.

Just before the 2010 presidential elections in Rwanda, a journalist lay dead and two others were fighting for their freedom. The dead journalist, Jean-Léonard Rugambage, had been a vocal critic of the government until he was gunned down in front of his house. The suspect who was later convicted for Rugambage's murder was sentenced to a mere 10 years imprisonment (BBC, 2010, June 25). Around the same time, two other journalists, Agnès Uwimana and Saïdati Mukakibibi, were respectively sentenced to 17 and seven years' imprisonment for violating the country's media laws. They had been convicted for crimes ranging from insulting the president to genocide denial.

Campaigners seized upon the disparity of the sentences for the convicted murderer and the two journalists (who only expressed unpopular opinions) as yet another sign of media repression in Rwanda (Terril, 2012, April 4). The Committee to Protect Journalists (CPJ), for example, said the government was using "vaguely worded laws to intimidate the press" (Committee to Protect Journalists, 2012, October 25). After an appeal to the Rwandan Supreme Court, the sentences for Uwimana and Mukakibibi were reduced to four and three years respectively. The government later introduced a raft of new legislation which it asserted would expand the frontiers of free expression in the country (Terril, 2012, April 6).

While welcoming these developments, campaigners made it clear that they were not sufficiently impressed because these measures didn't go far enough and that more was needed to ease the suppression of the Rwandan media. 
Thus on a ranking of 179 countries, Rwanda is placed 161 on the Press Freedom index compiled by Reporters Without Borders (RSF), on par with such countries as Laos, Sudan and Uzbekistan. The country's president, Paul Kagame, has repeatedly been named on the organization's list of "predators" of freedom of expression. "He affects to be modern-minded and is one of the most visible African leaders online (Facebook, viral propaganda and many sites supporting him) but this apparently open spirit is not real” (Reporters Without Borders, 2013).

It is not only international press freedom campaigners who criticize the Rwandan government's record on press freedom and free expression. Opponents of the regime also speak out loudly, often at the risk of prosecution, exile or even death. Boniface Twagirimana of the opposition United Democratic Forces party has been quoted as saying:

President Kagame is a dictator. He's operating like he's still in the forest as a rebel. He's not a president for the whole country, only RPF members. He doesn't want to open the political space to allow freedom of expression (quoted in Smith, 2012, October 10).

Kagame, however, seems unfazed by such criticism. He doesn't mind being called a hypocrite or a dictator. He believes he is doing the right thing by limiting free expression with laws many consider repressive. After so many reports and academic research into how the media was allegedly used as a tool for genocide, Kagame is convinced that the restrictions on free expression would prevent a recurrence of one of the worst human tragedies of the $20^{\text {th }}$ century:

Rwandans will not tolerate voices that promote a return to the ethnic divisionism that precipitated the genocide. To that extent, we place limits on freedom of expression in a similar way to how much of Europe has made it a crime to deny the Holocaust. Aside from that, Rwanda is a very open and free country (quoted in Smith, 2012, October 10).

This is a study into Kagame's assertion that he presides over "a very free and open society." It is an inquiry into the level of free expression and press freedom in post-genocide Rwanda and an 
attempt to determine whether the laws restricting free expression are reasonable and justifiable in the government's quest to rebuild the country and reconcile its people. It has been said that the purpose of journalism is "to provide people with the information they need to be free and selfgoverning" (Kovach and Rosenstiel, 2007, p. 12).

Amid all the reports about media repression in Rwanda, the question to be asked is whether or not journalism in Rwanda is performing this basic function within the context of the media regulatory regime in the country. Even though Kagame is an avid user of the internet and social media platforms, this study does not focus on these. The focus is on mainstream print and broadcast media outlets, a snapshot of which is provided in the table below.

\section{Media in Rwanda (2013)}

\begin{tabular}{cll}
\hline & Name & Ownership \\
\hline Newspapers: 39 & & \\
\hline \multirow{2}{*}{ Top 3 } & Imvaho & State-owned, bi-weekly \\
\cline { 2 - 3 } & The New Times & Privately owned, daily \\
\cline { 2 - 3 } & Kimyamateka & Owned by the Catholic Church, bi-weekly \\
\hline \multirow{2}{*}{ Top 3 31} & Radio Rwanda & \\
\hline & Contact FM & State-owned \\
\cline { 2 - 3 } & BBC World Service & Privately owned \\
\hline
\end{tabular}

TV stations: 2

\begin{tabular}{ll} 
TV Rwanda & State-owned \\
\hline TV 10 & Privately owned
\end{tabular}

News Agency: 1 Rwanda News Agency Privately owned Sources: IREX, 2012; Gasore, 2013

In examining the media and journalism in Rwanda, this study incorporates the wider issues of free expression and how restrictions on speech impact what Jürgen Habermas describes as the "public 
sphere." Habermas defines the public sphere as "a realm of our social life in which something approaching public opinion can be formed." He points out that:

Citizens behave as a public body when they confer in an unrestricted fashion that is with the guarantee of freedom of assembly and association and the freedom to express and publish their opinions - about matters of general interest. In a large public body, this kind of communication requires specific means for transmitting information and influencing those who receive it (Habermas, 1974, p. 49).

The media, therefore, is just one of the players in the public sphere, which "connects society with the state" (Habermas, 1996, p. 28). Political parties, civil society organizations, governmental institutions and nongovernmental organizations also feature prominently in the public sphere. Thus this study, while focusing mainly on the media in Rwanda, incorporates elements of how political parties and civil society organizations are allowed to operate and influence public opinion in the country.

Thomson identified three groups of people who dare to show dissent in Rwanda. The first group, known as abasazi (or foolish people) use "the impression that they are mentally unstable to justify their willingness to say what others will not." The second group, known as ibyibebe (or the fearless ones), "understood the risks of sharing their experiences and no longer feared speaking out because of hardships they had endured." Those in the second group are mostly genocide survivors who consider themselves as "walking dead" (Thomson, 2011, p. 449). Members of the third are known as ibipinga (those with deep-rooted principles). They include journalists, human rights activists and other intellectuals "who risk speaking out against the government because of their deep-rooted principles, despite their knowledge of potentially grave consequences" (ibid.). This study is about all three of these groups, as well as even foreigners who have incurred the wrath of the government by criticizing its policies and practices. 
This study is relevant because it is an examination of the quality of governance in Rwanda. Since the Rwandan constitution aims to "fight dictatorship by putting in place democratic institutions" (Republic of Rwanda, 2003, p. 1), this study will use one of the key benchmarks for measuring democratic rule - free expression, as exemplified by the ability of journalists to operate freely with the most minimal, reasonable and justifiable of constraints - to measure how the government is living up to its constitutional mandate of fighting dictatorship. As Kovach and Rosenstiel point out, "the more democratic the society, the more news and information it tends to have" (Kovach and Rosenstiel, 2007, p. 16). Thus the extent of media freedom is a barometer for measuring and testing the democratic credentials of the Rwandan government.

The study can also be considered a contribution to the process of rehabilitating the media in Rwanda. There is little doubt that in the run-up to the genocide, and, indeed as it unfolded, the media was used as a propaganda tool to preach hatred and, in some cases, give directions and instructions for killings. For example, Melvern describes "a pervasive racial ideology and propaganda" (Melvern, 2004, p. 62) in the period leading up to the genocide. Mushikiwabo writes about "an artful propaganda apparatus" being used to "enlist hundreds of thousands of ordinary people to kill hundreds of thousands of other ordinary people (Mushikiwabo, 2006, p. 55) and Des Forges asserts that "propagandists echoed and magnified the hatred and suspicions sown by [the organizers of the genocide]" (Des Forges, 1999, p. 57).

Three of such propagandists are serving jail terms for their roles in the genocide, but it appears that Rwandan journalists today are also paying for the crimes of these convicts by having to contend with restrictions put in place ostensibly to prevent them from inciting another genocide. This study will contribute to the debate on these restrictions, pointing out which arguably can to be maintained and those which have outlived their necessity in Rwandan statutes. 
A rehabilitated and responsible Rwandan media would also serve as a very good example for media in other African countries, especially those emerging from conflict. Since Rwanda represents one of the most extreme example of the devastation of conflict and the harmful effects of the scourge of propaganda, building a free press there would be a statement to other African governments that they have no excuse to keep their media shackled. On the other hand, the Rwandan media restrictions provide an example and a justification for other African governments to restrict press freedoms with the excuse that they do not want the media to be used, as was done in Rwanda, to promote ethnic animosity.

Much of the information for this study comes from the extensive literature on Rwanda, the genocide and the government's program of reconstruction and reconciliation over the past two decades. Since this is about Rwanda, the best place to conduct such a study would have been in Rwanda itself, but practical concerns over security compelled the author to pursue this project from Canada, a world away. The ethical and security concerns mostly stem from an overwhelming belief in the academic community that Rwanda is a difficult place to conduct research. Citizens are said to be quite reticent, reluctant to speak freely and openly, aware of the restrictions that form the basis of this study. When people do take the risk to speak freely, there is also the fear that they would be perceived as enemies of the state and supposedly either hounded into exile or severely censured for daring to speak their minds. A stark warning from the British government to exiled Rwandan dissidents that "the Rwandan government may be plotting to kill them" (Kron \& Gettleman, 2011, May 19) rendered going to Rwanda even more of a dangerous endeavour that could place prospective interviewees and the researcher at risk. As the study progressed most of prospective interviewees who had initially expressed the desire to contribute to this research, 
abruptly cut communications with the author. This was especially the case with Rwandans, even those domiciled abroad.

The inability to go to Rwanda has therefore been a major limitation on this study. This limitation can be corrected in the future as more researchers take an interest in the development of the Rwandan media and as the government sincerely works to make itself be seen as less of a threat to those who speak openly against it. One can only hope that this study would contribute to bringing this change about. 


\section{Chapter 1}

\section{MEDIA AND POWER}

Rwanda's first post-colonial head of state, Grégoire Kayibanda, wore many hats before he came to occupy the highest office in the land. He was a Hutu by ethnic affiliation, a teacher, a freedom fighter and a private secretary to the Pope's ambassador in Rwanda. He also worked for almost a decade as a journalist, editing the Catholic periodicals, L'Ami and Kinyamateka. The French academic, Gerard Prunier suggests that the Catholic Church into which most Rwandans were baptized, used Kinyamateka (established in 1935) as "one of the main organs" that pushed for the social and political changes that ended colonialism in Rwanda (Prunier, 1995, p. 44).

"In the hands of Grégoire Kayibanda," Prunier says, "[Kinyamateka] became the most read organ in Rwanda, with a circulation of about 25,000" (Prunier, 1995, p. 46). Kayibanda used Kinyamateka to promote his ideas and vision for the future of his country until he became head of state. A few years into his presidency, however, Kayibanda outlawed the newspaper he had helped popularize. The newspaper he had used to a very large extent to push for the independence of Rwanda had suddenly become a liability for Kayibanda. By banning Kinyamateka, Kayibanda made it clear that he would not tolerate dissent. Press freedom and free speech, he seemed to suggest, were not worthy ideals to which the nascent nation should aspire.

When Kayibanda was overthrown by his ethnic kin and defense minister in 1973, Kinyamateka staged a comeback, this time as "the herald of the regime of Juvénal Habyarimana" (Frère, 2007, p. 82). For several years, Kinyamateka and the government information agency Habyarimana established to oversee the state-controlled broadcast network were the only sources of news and information in Rwanda. "For decades, two pillars of Rwandan society, the state and the Catholic church, had exclusive right over all information channels of the national media 
landscape," Frère points out. "The Office Rwandais de l'information (ORINFOR), established in 1974 to replace the Ministry of Information, exercised its authority over the whole of the media of the state: the Kinyarwanda newspaper Imvaho (The Truth) and the francophone newspaper, La Relève; the Agence Rwandaise de Presse (ARP), which had exclusive access to information coming from abroad; and Radio Rwanda, created in 1961" (Frère, 2007, p. 82).

Being one of the two major providers of information in the country, however, did not mean that the Catholic Church and Kinyamateka had free rein. Once in a while the paper would be reprimanded for its "tendency to occasionally adopt a critical tone" (ibid.). Around the same time in the early 1980s:

Another publication, the monthly Umunyamuryango Trafipro, linked to a co-operative [that had once been headed by Kayibanda] and therefore to the emergence of a new civil society, tried to distinguish itself from the official voices, but its publication was suspended in 1985 after much pressure (Frère, 2007, p. 82).

It was not until 1988 that the government allowed privately owned news publications as the Habyarimana regime started bowing to international pressure to end its one-party domination of the republic. Those demands intensified and became even more urgent as a rebel army, dominated by members of the minority Tutsi ethnic group launched its first raids on Rwanda in October 1990. Multiparty democracy was seen as the surest way to end the civil war with the rebel Rwandan Patriotic Front. After one of the RPF's most daring raids in January 1991, during which a prison was cleared of most of its inmates, government forces staged reprisals against some Tutsi civilians, reportedly massacring dozens in the northwestern parts of the country. Human Rights Watch reported that:

While the massacre was widely discussed among Tutsi in Kigali, the capital, there was no press coverage of the incident until June 20, when the Belgian newspaper L'Instant broke the story. The Rwandan government did not acknowledge that any killings had occurred until August 14, the day after the RPF held a news 
conference denouncing the killings. The Rwandan ambassador to Belgium then reportedly admitted that "a massacre of Tutsi civilians had occurred in the region." He did not specify the number of casualties and blamed the RPF for the killings. He also indicated that the government had commenced an investigation into the matter and that those responsible would be prosecuted (Human Rights Watch, 1992).

The massacres could not be reported in the local media because the government had essentially sealed off the theatre of war, preventing journalists it couldn't trust to convey its version of events from going to the area where they had occurred. The government reprisal against the Tutsi civilians brought the ethnic acrimony that had been simmering in the country after the launch of the RPF insurgency to a boil. Meanwhile, Hutu from the south (Kayibanda's domain) were jostling for power with the ruling Hutu elite from the north (Habyarimana's domain).

With the country so divided along ethnic and regional lines, news outlets became a vehicle to drive the ambitions of those who either sought power or proximity to power. Most of the newspapers that emerged in this climate of war and the attempts at democratic reform didn't even pretend to be committed to the journalistic ideals of accuracy, balance and impartiality. Both their owners and the staff they recruited saw these media outlets as means to an end, vehicles to further parochial, political aspirations - many of them linked to the ethnic and regional divisions in the country. "A partisan press" had been born, according to the Belgian academic, Filip Reyntjens, "without a code of conduct, practising defamation and denouncement," (quoted in Frère, 2007, p. 84).

Higiro has classified the newspapers which emerged in Rwanda in the early 1990s into four categories. The first category included newspapers aligned with the Habyarimana regime. The most prominent of these newspapers was Kangura, which would become well-known at the end of 
the genocide as one of the most extremist publications the world has ever seen. Kangura and the other pro-government papers:

Praised the [ruling] MRND [party] and President Juvenal Habyarimana's leadership and offered space to MRND leaders to respond to criticisms leveled at them by the editors of other newspapers and leaders of opposition parties. They depicted Habyarimana as the guarantor of peace and the MRND as the political party of true patriots. Opposition leaders were portrayed as puppets [of the rebel movement], traitors and embezzlers of public funds, demagogues, opportunists and idiots motivated by the desire to settle scores with President Habyarimana (Higiro, 2007, p. 74).

The second group of newspapers in Higiro's classification were those which were mouthpieces for the emerging opposition political parties. The most prominent of these was Kanguka, established in 1988 and funded by a businessman from the ethnic Tutsi minority. These publications, Higiro points out:

Presented MRND leaders as evil and corrupt, liars, idiots, animals, bloodthirsty murderers and warmongers. Some published drawings [depicting] President Habyarimana [drenched in] blood. These newspapers portrayed opposition leaders as peace-loving people capable of ending the war. They disseminated the view that the [continuation] of the war was something that President Habyarimana and the MRND wanted to keep them in power. According to these newspapers, opposition leaders had a solution to the war (Higiro, 2007, p. 75).

Newspapers supporting the RPF guerrillas fall into Higiro's third category. While hailing “the RPF armed struggle," these outlets "never published stories about the assassinations, the abductions or the destruction for which the RPF was responsible as it advanced from southern Uganda in its quest for power," according to Higiro. "If they printed stories about violence in the demilitarized zone or buffer separating Rwandan government forces and RPF forces, they attributed it to the army of Habyarimana, a derogatory label for the [national army] (Higiro, 2007, p. 76).

The last category in Higiro's grouping of newspapers in Rwanda in the early 1990s consisted of those publications which claimed to be representing the country's largely Tutsi 
community in exile. The best known of these newspapers, Impuruza, was published in the United States, featuring "articles on the condition of the Rwandan Tutsi diaspora" (Higiro, 2007, p. 77).

Thus at the start of the last decade of the $20^{\text {th }}$ century, the domination of the Rwandan media landscape by the Catholic Church and the government had effectively ended. The terrain, however, had been taken over not by journalists of conscience and professionalism, but by propagandists and political activists:

Many editors and journalists were militants in the political parties they worked for and were well respected in those political parties. The journalists who were on the side of the ruling party, the MRND, behaved as intelligence agents of the state: ordinary citizens were afraid of them (Higiro, 2007, p. 78).

If ordinary citizens feared pro-government journalists, the government itself became increasingly paranoid about the growing influence of the journalists who were not on its side - essentially all the journalists who either demonstrated support for the opposition or those whose allegiances were in doubt. This influence was mostly discernible among the educated and middle class elite in the capital, Kigali. Much of the country was illiterate and couldn't afford newspapers, according to Higiro (2007) and Frère (2007). Most of these newspapers were not even circulating outside Kigali and all but the best-funded were struggling financially. Higiro points out that:

The number of readers a newspaper had depended on its political leanings. The buyers of the newspaper and the financial supporters were members of the political party the newspaper had chosen to support. The newspapers that sided with political parties that had money were the ones that were viable and published regularly. Those supporting the [ruling] MRND and the RPF fall into this category (Higiro, 2007, p. 79).

In this climate where almost every journalist appeared to have sold his or her allegiance to one faction or the other on the basis of the separate but interlinked affiliations of ethnicity or political ideology, the only people who seemed minded to report on events in the country without any considerations of gaining access to power were human rights activists. Since they tended to use 
the media to broadcast their findings, much of the government's policies aimed at silencing critical and dissenting voices targeted political and human rights activists as well as journalists, who were the primary targets.

The government first started to muzzle the press by using emergency laws, which had been activated as a result of the raging civil war. These laws, for example, placed severe restrictions on the movement of people, including journalists. Under these laws, no one could even change residence within the same suburb in the same town or city without government authorization. This meant that journalists could not travel around the country to verify allegations of human rights violations, which were being made by both the government and the rebel movement. "The tight controls on the right to freedom of movement made it easier, in many cases, for the authorities to cover up human rights abuses and to further promote their version of events, both about the war and state-sponsored violence," according to Article 19, an international NGO that advocates for media rights and freedoms around the world. "The latter was generally described by officials as either a direct result or a by-product of the war, if not attributable to the RPF itself' (Article 19, 1996, p. 22).

The most serious legal impediments for journalists, however, were vaguely worded laws that outlawed reporting on issues the government insisted should be out of bounds for media discussion. These included legislation on sedition which stipulated that it was a crime to "incite the population to revolt against the established authorities, either to incite or attempt to incite conflict amongst the population or to cause alarm and seek to bring turmoil to the territory of the republic" (quoted in Article 19, 1996, p. 26). These laws made it a crime to even report on losses suffered by the army. In one instance, to signal its displeasure with journalists, the Council of Ministers placed an announcement on the state-controlled Radio Rwanda, warning that: 
Freedom of speech should be carried out within the limits set by the laws and regulation in force in our country. The exercise of this freedom should not be synonymous with disinformation, intoxification [sic] and more importantly, not be an attack on the morale of the armed forces. The national press is therefore called upon to stop publishing subversive items which, by their nature, weaken the national cohesion which is needed more today than ever before in order to win the war (quoted in Article 19, 1996, p. 29).

A few weeks after this announcement, four journalists were arrested and detained for "consciously

or unconsciously playing the enemy's game," according to a government minister. They were

detained for "several months and then released:"

The December 1991 communiqué by the FAR, broadcast on Radio Rwanda, which claimed that sections of the independent media were working for the RPF, also served to intimidate journalists. Immediately after the broadcast, seven journalists went into hiding for several weeks. Two of [them] were arbitrarily detained less than a week after the broadcast (Article 19, 1996, p. 29).

Many journalists complained about these arrests, arguing that the so-called security measures amounted to unjustifiable restrictions:

In May 1991, several journalists signed a letter to the president protesting what they termed "the censorship orchestrated by certain authorities with regard to the independent press." Since the beginning of the year, the government has arrested at least ten journalists in connection with articles they had written and charged many of them with defamation, subversion or "threatening state security." Many of the offending articles relate to government corruption, including within the president's family. At least four journalists were detained in late November, one was badly beaten, and several others are in hiding. Some also face civil defamation charges initiated by former or current government officials (Human Rights Watch, 1992).

The government responded to these complaints by passing a new press law, which superficially appeared to enhance press freedom. But Higiro stresses that the press law of 1992 gave very little and took much away. "While claiming to recognize freedom of the press, its emphasis was on how to restrict that freedom" (Higiro, 2007, p. 83). About this law, Frère also points out that "it 
reinforced the repression of opposition papers and encouraged the most extremist" (Frère, 2007, p. 84).

While enforcing these laws with the heavy-handedness of an autocratic regime on a war footing, the government also tried to use simple, subtle persuasion to co-opt journalists. For example, the head of the agency overseeing all government-controlled media outlets proposed the establishment of an umbrella organization of journalists "supposedly to defend their interests," according to Higiro. "But in fact, he wanted to use [this organization] to influence the content of newspapers" (Higiro, 2007, p. 83). Pro-government journalists bought into the idea and formed the Union of Rwandan Journalists. The opposition journalists and representatives of the Catholic periodical, Kinyamateka, came together to form their own organization, which they called the Association of Rwandan Journalists. With the formation of these two groupings, it became clear to the government that much of its attempt to clamp down on the press had failed. In previous years, when the president's whims could be turned into law and the regime was under no pressure to end its one-party domination, things would have been done differently. A terse presidential decree banning all the newspapers could have silenced everyone and allowed the government to maintain its monopoly over the media landscape. But times had changed and presidential fiat was not an option. Feeling besieged on all fronts, the government resorted to the use of violence and intimidation.

In 1992, Radio Rwanda's Straton Byabagamba became the country's first journalist to be assassinated (see Frère, 2007). He was stabbed in his home in Kigali. Four members of an extremist party within the governing coalition were arrested, but later released. By this time, the ruling party and its affiliates had established militia groups whose sole mandate, it seemed, was to use violence to harass and intimidate opponents and critics, people considered to be accomplices 
of the rebel RPF. Journalists, human rights activists, political opponents and even ordinary citizens who spoke in support of the negotiations for peace were especially targeted. Those who killed Byabagamba belonged to one of these militia groups. Byabagamba was not, however, the first journalist the militia physically assaulted. "Just as formal respect for freedom of expression was improving, government critics were increasingly subject to informal repression with the emergence in 1992 of militias affiliated to the MRND and the extremist CDR," according to the NGO, Article 19. "In addition to orchestrating state-sponsored violence, these militias played a major role from 1992 onwards in attacking and intimidating government critics, particularly journalists and human rights activists:"

For example, on 6 April 1993, television producer, Callixte Kalisa, was shot dead close to his home in Remera, Kigali. He had found a grenade near the entrance to his home several days before. In early May, Ignace Ruhatana, editor of

Kanyarwanda, published by the human rights group of the same name, was attacked by a group of unidentified people who attempted to steal his documents on human rights issues. Several months later, in mid-November 1993, the prominent human rights activist and then public prosecutor, Alphonse-Marie Nkubito, was the target of a grenade attack just outside his home. Though seriously injured, he survived the attack. Although it was often not possible to prove precisely who was responsible for a given attack, in some instances militia leaders [openly] admitted that they were planning to harass or eliminate particular individuals (Article 19, 1996, p. 30).

In one case, a stringer for the BBC Swahili Service was spared the agony of a violent attack only after he went to apologize to a militia leader who had taken umbrage at a report detailing clashes between some members of the ruling coalition. "The militia leader is reported to have admitted that earlier he had ordered several members to assault [the journalist] that very evening," according to the NGO, Article 19. The militia leader said he "he was persuaded by [an] MRND member [who informed the journalist about the impending attack] to cancel the plan" (Article 19, 1996, p. 31). 
At the same time, the government maintained a near-absolute monopoly over the only broadcast network in the country, Radio Rwanda. So firmly was Radio Rwanda under the stranglehold of the government that a UN special envoy, investigating human rights violations in the country, expressed concern that the network often carried two different versions of his reports - the French version for international ears and a stilted Kinyarwanda version for Rwandans. "The two language versions," he said "contradicted each other" (quoted in Article 19, 1996, p. 25).

The only alternative to this state-controlled network was Radio Muhabura, the clandestine station operated by the RPF rebel movement. Broadcasting illegally on shortwave from nearby Uganda, Muhabura, had limited coverage, almost an insignificant listenership and a very narrow focus. "Although this station broke the government monopoly on broadcasting, it did little to contribute to the free flow of information," the NGO, Article 19, points out. "[It] continued the culture of propaganda and counterpropaganda, providing little concrete information about events and spending a lot of air time presenting and promoting the RPF to the Rwandan population" (Article 19, 1996, p. 24).

Having captured a significant portion of the print media terrain, the opposition started demanding some space on Rwanda's airwaves. With the establishment of a government of national unity in 1992, Habyarimana met the opposition's demand, ceding control of both Radio Rwanda and its supervising agency, the Office Rwandais de l'information (ORINFOR) to opposition elements. This concession came after a long dogged fight, which culminated in each of the opposition parties getting a weekly 15-minute slot on the public radio network to present their views to Rwandans. It wasn't much and as the NGO, Article 19, points out: 
Overall reporting remained heavily biased in favour of the MRND. ORINFOR's interim director allowed several journalists close to President Habyarimana to maintain control of most of the important news programs at Radio Rwanda. [The interim director] was not a journalist and, as a result, reportedly gave department heads complete autonomy, making no effort to check their pro-MRND bias (Article 19, 1996, p. 25).

Even though they maintained monopoly over much of Radio Rwanda's airwaves, the loss of absolute control over the network was too much for the regime's hardliners to take. In 1993, for example, they organized a pro-government rally at which some of the protesters carried placards with slogans such as "Free Radio Rwanda."

According to Prunier, "Radio Rwanda reporters, feeling that change was in the air, were beginning to show a sense of independence and to report what was actually going on even if the news they carried was not particularly favourable to the regime" (Prunier, 1995, p. 164). One of Radio Rwanda's best known and most respected journalists at the time was Thomas Kamilindi. "As a simple journalist, the only weapon I had was to report the facts and only verifiable facts," he says. "But even that was difficult because it brought me many problems" (Kamilindi, 2007, p. 137).

One could say that some of those problems Kamilindi found himself in could have been minimized if he had not been a card-carrying member of an opposition party. Seen as an opposition figure with a loud voice on state radio, it was easy for the government to target Kamilindi. His insistence on greater independence for the network, going as far as to lead a strike, were interpreted as actions motivated by his desire to see the Habyarimana regime out of power. He was seen as a liability, along with many other journalists who had aligned themselves with the opposition. Under these circumstances, the schism between journalists on the government's side 
on the one hand and those deemed to be with the opposition and the rebel movement on the other hand, kept growing.

Over time, this split took on a very distinct ethnic tinge as the regime decided to use Rwanda's history of ethnic divisions as fodder for a propaganda effort it hoped would help it win both the military and political campaigns. It was the same history that brought Kayibanda to power as Rwanda's first Hutu leader. That history informed and influenced the attempt to exterminate the minority Tutsi ethnic group, in what has been described as "tropical Nazism" (Pottier, 2002, p. 31). It was the same history that would drive the birth of one of the most extremist hate media outlets the world has ever seen. And it is that same history that is used as a pretext for the regulations that govern the Rwandan media today. Understanding that history engenders a much deeper appreciation of why the Rwandan media is in the situation it is in today. As Siebert et al postulate:

The press always takes on the form and coloration of the social and political structures within which it operates. Especially, it reflects the system of social control whereby relations of individuals and institutions are adjusted. An understanding of these aspects of society is basic to any systematic understanding of the press. To see the social systems in their true relationship to the press, one has to look at certain basic beliefs and assumptions which the society holds: the nature of man, the nature of society and the state, the relation of man to the state, and the nature of knowledge and truth (Siebert et al, 1956, pp. 1-2).

In the case of Rwanda, all these factors boil down to the relationship between the country's two main ethnic groups - Hutu and Tutsi; the former in the majority (about 85 percent of the population), the latter in the minority. How the two groups came to inhabit the hills of Rwanda and how they have looked at each other for centuries is key to understanding Rwandan society, its political system and the media culture this system has produced. 


\section{Chapter 2}

\section{ALIENS AND LOCALS}

By all accounts, Léon Mugesera was one of the most powerful and influential men in Rwanda in the last decade of the $20^{\text {th }}$ century. He was an intellectual and a leading political operative for the ruling party known as Mouvement Révoluionnaire National pour le Dévelopment (MRND). But as 1992 drew to a close, Mugesera was a wanted man. The justice minister had issued a warrant for his arrest for allegedly inciting racial hatred and murder. The charge stemmed from a speech Mugesera delivered at a political rally in the township of Gisenyi. "What are we waiting for?" he asked. "They belong in Ethiopia and we are going to find them a shortcut to get there by throwing them in the Nyabarongo River. We must wipe them out" (quoted in Prunier, 1995, pp. $171-172)$.

The "they" Mugesera was referring to was a group in Rwanda known as the Tutsi, variously identified either as an ethnic group or an invading race. For Mugesera and his ilk, who belonged to the majority Hutu grouping, the Tutsi did not belong in Rwanda; they either had to leave voluntarily or the Hutu needed to force them out. It was a notion that entered Rwandan society at the dawn of colonialism and stayed in the minds of millions and bred hatred in many hearts, culminating in the eventual murder of hundreds of thousands. It was known as the Hamitic hypothesis, which is the belief that "everything of value ever found in Africa was brought there by the Hamites, allegedly a branch of the Caucasian race" (Sanders, 1969, p. 521). Sanders adds that the Hamitic hypothesis:

Is a convenient explanation for all the signs of civilization found in Black Africa. It was these Caucasoids [or Hamites] we read, who taught the Negro how to manufacture iron and who were so politically sophisticated that they organized territories into highly complex states with themselves as the ruling elites (Sanders, 1969, p. 532). 
Nowhere in Africa did the Hamitic hypothesis gain deeper roots than in Rwanda, where the Tutsi were considered to be Hamites. Not only did they have "distinct physical features" (Prunier, 1995, p. 16), but they were also the country's ruling elite. And so when the colonialists arrived in this territory with the belief that the Black African could not create anything of value, they fell on the Hamitic hypothesis and pointed to the Tutsi as the alien, civilizing race that had come from either North Africa or somewhere near Ethiopia.

The "alien" Hamitic Tutsi, the colonialists reckoned, were the brains behind Rwanda's complex political organization. By the middle of 1992, as Mugesera asked for the Tutsi to be shown a "shortcut to Ethiopia by throwing them in the Nyabarongo River" (quoted in Prunier, 1995, p. 172), the Hamitic hypothesis had been scientifically and historically discredited as a racially offensive doctrine (see Sanders, 1969). In Rwanda, however, its roots were so deep and firm that even intellectuals continued to believe in it. Two years after Mugesera's speech, Tutsi corpses were impeding the flow of the Nyabarongo River (Gourevitch, 1998, p. 53). The Hamitic hypothesis had taken a deadly toll.

Running from the law, Mugesera sought refuge for nearly 20 years in Canada, from where he was deported to Rwanda in 2012 to face charges of inciting hatred (Buck \& Uwiringiyimana, 2013, November 17). But he was neither the first nor the last person to speak so virulently against the Tutsi. He was, however, among the first generation of Rwanda's post-colonial intellectual Hutu elite who bought into the myth and the fallacy of the "Hamitic hypothesis" and went to great lengths to make sure that the Tutsi were treated as the aliens they supposedly were.

There are many aspects of Rwandan history that spark long, heated debates among historians. Much of these debates revolve around the questions of who the Hutu and Tutsi are 
and why one group found it necessary to try to exterminate the other. Theories abound, but the most popular ones prominently feature one animal - the cow. As one traces Rwandan history it becomes clear that it mattered a lot who owned a cow (or herds of cattle) and who didn't.

Indeed, it might seem that no account of Rwandan history would be considered complete without the mention of cattle and even today these beasts play a key role in Rwandan society and culture. "The specific potential of cattle for obtaining social and political success must be appreciated," the historian Jean-Pierre Chrétien suggests. "Cattle, as mobile capital, provided the capability for exchange and influence" (Chrétien, 2006, p. 81). So important are cattle that, according to Louise Mushikiwabo, a man "can pay a woman no greater compliment than to call her a cow" (Mushikiwabo, 2006, p. 5). Mushikiwabo also lends credence to Chrétien's suggestion about cattle conferring prestige and influence on those who own them:

In America, agronomists spend their days bending the bloodlines of cattle to produce flank steaks cheap, fast and in enormous quantity. In Rwanda, it is just the opposite. Tradition gets people doing their bloody best to make sure the cattle get fed. Eat the beast? What indulgence! Making a meal of something you work so hard to keep alive? The only bovine flanks we care about are flanks that quiver with life in the morning light of mountain pasture (Mushikiwabo, 2006, p. 150).

This is what Claudine Vidal describes as the "fetishization of the cow" (quoted in Chrétien, 2003, p. 81) and with the passage of time, it determined who was a Hutu and who was a Tutsi. This much most historians agree on. What is in dispute, however, is: who were the first occupants of the tiny splice of planet earth known today as Rwanda? Some theorists suggest that the initial settlers were people who tilled the land. They were joined a little later by pastoralists who found in this area suitable pasture for their cattle.

But Chrétien insists that before the Hutu and Tutsi identities took shape, the farmers and the pastoralists had managed to build a community so fused (speaking the same language, 
intermarrying and observing the same cultural traditions) that it didn't matter who settled first and who followed. The chronology of settlement mattered even less because long before the influx of the pastoralists, there were significant numbers of cattle herders among the first settlers. In the circumstance, what mattered most in differentiating between the settlers in this area was the economic activities that occupied their lives:

When one refers to the distant origins of the internal categorization that marks the [African Great Lakes] region's societies, notably in the western part, two kinds of answers are possible: on the one hand, populations with different geographic origins and from different linguistic families encountered one another; on the other hand, a socio-economic cleavage developed between largely agricultural groups and largely pastoral ones, each of which found a different ecological niche for itself (Chrétien, 2003, p. 74).

This "socio-economic cleavage" later came to define the identities of Hutu and Tutsi; the former in the majority, the later in the minority. As socio-economic identities and largely dependent on the ownership of cattle, being Hutu or Tutsi wasn't a permanent condition. A Tutsi who lost all his cattle to disease one day could find himself categorized as a Hutu the next day; and a Hutu who suddenly gained cattle would move up the social ladder to become a Tutsi, literally gaining prestige and influence on the back of a cow. In fact, there was a particular social arrangement that made it possible for a Hutu to be "de-Hutuized" and, thereby, become "Tutsified." "In the classical form of ubuhake, a Tutsi patron gave a cow to his Hutu client," Prunier points out. "It was not only an 'economic' gift but also a form of upward social mobility" (Prunier, 1995, pp. 1314).

At this point, it is important to make clear that the Tutsi minority, with the wealth and prestige stemming from the ownership of cattle, constituted the ruling elite in the pre-colonial kingdoms that later became Rwanda. And so cattle ownership, which marked a "socio-economic cleavage” (Chrétien, 2006, p. 74), gradually and eventually defined political power as well. Thus 
Mahmood Mamdani observes that being Hutu or Tutsi in the fullness of time became "political identities that have changed from one historical period to another" (Mamdani, 2001, p. 15).

Jan Vansina asserts that Tutsi "referred mostly to a political elite" (Vansina, 2004, p. 37), with a Tutsi king (Mwami) at the head of the Rwandan monarchy on the eve of colonialism. Below the Mwami on the hierarchy of power were sub-chiefs who were also mostly Tutsi even though there was a fairly significant sprinkling of Hutu lords in the precolonial Kingdom of Rwanda (Mamdani, 2001, p. 90). However, it was not a period of peaceful ethnic harmony. This point is worth noting because it helps put the current Rwandan government's portrayal of history into perspective. The current regime insists that there were no Hutu or Tutsi in ancient Rwanda and that citizens of the kingdom in centuries past lived in peaceful harmony. Much of the available evidence, however, point to the fact that there was a lot of political intrigue inside the Tutsi royal court as well as rebellions spearheaded by Hutu upstarts. In other words, Tutsi jostled violently with Tutsi, even in the royal courts. "On the occasion of each succession, even the most straightforward ones, the kingdom entered into crisis" (Vansina, 2004, p. 100). Hutu fought among themselves on the periphery. And the two groups faced off with each other every once in a while. Hutu chiefs who resisted the expansion of the kingdom that eventually became Rwanda, were violently brought to heel.

Order and harmony was often restored only after the kings had asserted their authority with the brutal show of force. For example, in the $18^{\text {th }}$ century, Tutsi lords refused to recognise the new king, Gisanura. Somehow, he died suddenly of an infected wound. The king who succeeded him, Mazimpaka, "exterminated all of the son of his brother and rival because they remained opposed to his succession" (Vansina, 2004, p. 101). That, however, did not stop others from attempting to overthrow him. There were also the murders of his half-brothers, at the 
instigation of the relatives of his own queen mother. Mazimpaka's response was to order the massacre of all of the queen mother's relatives and clansmen. Later, when the king learned that two of his wives had supposedly bewitched him he had them executed and "then followed a reign of terror during which [Mazimpaka] is said to have killed his own son by mistake," according to Vansina. "Faced with this royal paranoia, all the important personalities fled the court" (Vansina, 2004, p. 101).

The last great king of Rwanda before colonialism, Rwabugiri, was noted both for his bravery in battle and his brutality at court, both of which led to the greater centralization of power in the Tutsi king. It was one of the most violent periods in the kingdom's history:

War was but one manifestation of the politics of violence. Judiciary violence directed against once rivals was another one. Such accusations or denunciations made during the evening meetings were the main tool of the courtiers for eliminating their adversaries, whether for the purpose of obtaining their wealth or out of sheer hatred. It was a terrible weapon in part because of the king's character. Rwabugiri, who was touchy, impulsive, irascible, very suspicious by nature and thought himself to be crafty was easily convinced of treason. Quite frequently he immediately condemned the accused and his whole family to death, sparing a child to provide for their ancestor worship. Accusation was above all a political tool and it is through denunciations that this credulous or Machiavellian king ratified the shifts in power that occurred under him (Vansina, 2004, p. 185).

The differentiation between the two main ethnic groups started getting ossified under the reign of Rwabugiri, starting with what Vansina describes as "the institutionalization of a humiliating differentiation" of the two groups "in the exploitation of the population both within the armies and especially within the corvée labour imposed on farmers [Hutu] but not on herders [Tutsi]" (p. 192, emphasis in original).

When the first European explorers arrived in Rwanda, therefore, they met a situation where most of those who wielded political authority were referred to as Tutsi, enjoying the privileges of power. The Hutu, on the other hand, were mostly left to endure the indignities of 
having most of their number excluded from the corridors of power, performing laborious duties for their Tutsi masters. The explorers were also struck by what they saw as the differentiation in the physical characteristics of the ruling Tutsi elite and the oppressed Hutu masses. The Hutu were described in a colonial document as "generally short and thick-set with a big head, a jovial expression, a wide nose and enormous lips" (quoted in Prunier, 1995, p. 6). As for the Tutsi, according to what was later to become the colonial narrative, they appeared to be from a completely different world, a different racial stock, endowed with more intelligence than the Hutu:

The [Tutsi] of a good race has nothing of the negro, apart from his color. He is usually very tall, $1.80 \mathrm{~m}$ at least, often $1.90 \mathrm{~m}$ or more. He is very thin, a characteristic which tends to be even more noticeable as he gets older. His features are very fine: a high brow, thin nose and fine lips framing beautiful shining teeth. [Tutsi] women are usually lighter-skinned than their husbands, very slender and pretty in their youth, although they tend to thicken with age... Gifted with vivacious intelligence, the Tutsi displays a refinement of feelings which is rare among primitive people. He is a natural-born leader, capable of extreme selfcontrol and calculated goodwill (quoted in Prunier, 1995, p. 6).

Thus, an ideology that positioned the Tutsi as racially superior to the Hutu was added to the widening social, economic and political schism between them. At this stage, the seeds of the "Hamitic hypothesis" were being sown. Leading the charge to make it gain firm roots was the British explorer, John Hanning Speke, who held very low opinions of Negroes and believed that only colonialism could bring redemption:

As his father did, so does he. He works his wife, sells his children, enslaves all he can lay hands upon, and unless when fighting for the property of others, contends himself with drinking, singing, and dancing like a baboon to drive dull care away" (quoted in Gourevitch, 1998, p. 52).

About the Tutsi in particular, Speke wrote that:

[They] differ absolutely by the beauty of their features and their light colour from the Bantu agriculturalists of an inferior type. Tall and well-proportioned, [the Tutsi] have long thin noses, a wide brow and fine lips. They say they came from the North. Their intelligence and delicate appearance, their love of money, their 
capacity to adapt to any situation seem to indicate a Semitic origin (quoted in Prunier, 1995, p. 8).

Gourevitch summarizes Speke's main theory as one in which the British explorer believed that "all culture and civilization in Central Africa had been introduced by the taller, sharper-featured people, whom he considered to be a Caucasoid tribe of Ethiopian origin, descended from the biblical King David, and therefore a superior race to the native Negroids" (Gourevitch, 1998, p. $51)$.

By the time the first Belgian colonialists took possession of Rwanda (after a brief stint by the Germans) they had already bought into the so-called scientific theories of Speke and his cohorts. "The Belgians could hardly have pretended that they were needed to bring order to Rwanda," according to Gourevitch. "Instead, they sought out those features of the existing civilization that fit their own ideas of mastery and subjugation and bent them to fit their purpose" (1998, p. 55). Thus Pierre Ryckmans, a key colonial administrator, wrote that "the [Tutsi] were meant to reign" and that it came as no surprise to him that "those good [Hutu], less intelligent, more simple, more spontaneous, more trusting, have let themselves be enslaved without ever daring to revolt" (quoted in Prunier, 1995, p. 11).

Throughout the colonial period, Rwandan society imbibed this toxic racial poison of Tutsi superiority and Hutu inferiority, as the colonialists introduced new political institutions and legislation prohibiting those traditional practices which made it possible for a Hutu to become a Tutsi. The Belgians, therefore, widened and fortified the socio-economic divide between Hutu and Tutsi into an iron-clad institutional framework, in which the Tutsi essentially became partners in the colonial enterprise. "To be a Tutsi was thus to be in power, near power, or simply identified with power - just as to be a Hutu was more and more to be a subject," Mamdani writes: 
If Hutu and Tutsi evoked the subject-power distinction in the precolonial Rwandan state, the colonial state gave it an added dimension: by racializing Hutu and Tutsi as identities, it signified the distinction as one between indigenous and alien. By making [the] Tutsi and Hutu identities evocative of colonial power and colonial subjugation - and not just local power relations - colonialism made them more volatile than ever in history (Mamdani, 2001, p. 75).

Throughout the colonial era, therefore, Hutu felt as if they were third-rate citizens; the colonialists were first-grade with the Tutsi coming second. Caught in the middle, the Tutsi also suffered colonial oppression but not as harshly as the Hutu. In other words, the Hutu saw themselves as suffering a double-barrelled colonialism: one at the hands of the new white arrivals, the other from the largely cattle-owning group with whom they had inhabited the same hills for centuries. By this stage the "Hamitic hypothesis" had gained roots and sprouted several branches under which the so-called "notorious twin-rivals of Rwandese society" (Prunier, 1995, p. 3) would come to brood over their mutual animosity towards each other.

The first of these branches was the educational system, operated by the Roman Catholic Church, which in Rwanda was a veritable subsidiary of the colonial state. School was the first place where Rwandan children came to experience the impact of being either a Tutsi or Hutu: The Tutsi were given "superior" education, taught in French in a separate stream. The assimilationist education prepared them for positions in government and testified to their preparedness for citizenship, even if at the lowest orders. In contrast, the Hutu were given an education considered "inferior," since they were taught in a different stream, one where the medium of instruction was Kiswahili (Mamdani, 2001, pp. 89-90).

The second branch of the "Hamitic hypothesis" was located in the structures of local government and administration the colonial government built to increase the Tutsi hold on power. This system of indirect (colonial) rule saw the appointment of Tutsi as chiefs at the local levels while deposing the few Hutu who had held similar positions previously. "The new chiefs were the products of schools for the sons of Tutsi chiefs," Mamdani says. "Nourished on a steady diet of Hamitic 
supremacy, they were appointed chiefs as if by birthright" (Mamdani, 2003, p. 91). The result was that "the parameters of local administrative power [were] rounded off into a local despotism" (Mamdani, 2003, p. 92), which would both increase Tutsi privilege and unwittingly deepen Hutu subjugation. Prunier adds that the "local Tutsi chiefs, secure in the white man's support, acted as rapacious quasi-warlords" (Prunier, 1995, p. 25).

The third branch of the Hamitic hypothesis, was, perhaps, the most insidious and the point where the Hutu truly felt the worst forms of oppression. This was where the Hutu were legally obliged to work for the colonial state for free, while simultaneously giving away a significant portion of their farm produce for whatever purpose the state decided:

The exactions constituted nothing less than a regime of force, ranging from forced labour to forced crops. These could be demanded of individuals for "educational" reasons, or of entire groups for "developmental" reasons. The standard punishment for anyone who reneged on an administrative requirement - whether it was forced labour, forced crops, or forced sales - was the kiboko, eight strokes with hippopotamus cane (Mamdani, 2001, p. 94).

The "exactions" and the humiliation that accompanied them seriously dented the Hutu psyche. With much of the punishment administered by Tutsi chiefs, it invariably bolstered the Hutu view that the Tutsi were as alien as the European colonialists, not neighbourly brethren.

To make matters worse, the Belgians realized that despite all the talk about the fine features of the Tutsi and the stocky physique of the Hutu, it was not always easy to tell them apart. There were stocky Tutsi without cattle and there were tall, slender Hutu with plenty of cattle. It was the sort of confusion that could make the most diligent colonial bureaucrat fudge the lines and offer Tutsi-only privileges to Hutu who didn't deserve them under colonial fiat. The colonial authorities therefore came up with the idea of issuing identity cards to help remove the ambiguities presented by physical appearances. The issuance of these cards started in 1933 after a 
national census, in which, once again, the ownership of cattle was used to determine who was Hutu and who was Tutsi. To be considered a genuine Tutsi, one needed to have at least 10 cows, and wherever ambiguities remained, men of God were called in to help categorize their parishioners:

The ten-cow rule... was neither the only nor even always the main basis for identification of the Tutsi. The state relied heavily on data provided by the Roman Catholic] Church, whose local servants knew very well their neighbours and their genealogy... The census marked the end point of a process through which the colonial power constructed the Tutsi as nonindigenous and the Hutu as indigenous. Through this distinction between alien and indigenous, the Tutsi came to be defined as a race - the Hamitic race - different from the Hutu, who were constructed as indigenous Bantu (Mamdani, 2001, p. 99).

With the imagined differences between the two groups now legally recognized and set in bureaucratic stone, the identity cards served as a Tutsi passport to privilege. For the Hutu each official request to show an ID card was a reminder of the frustration and humiliation of being so classified and treated as a third-grade citizen, with limited rights and restricted access to vital services.

Once again, it must be pointed out that education was one area where the Hutu felt most restricted, underprivileged and deprived. Most Hutu had difficulty gaining any form of education above the basic education the colonial administration decided was all they needed:

To obtain any kind of post-secondary education, the Hutu had no choice but to become theology students. After graduation, they tended to experience difficulties finding employment corresponding to their level of education, and often became embittered and frustrated (Prunier, 1995, p. 33).

The Hutu frustration was exemplified by a steady stream of Hutu migrants into neighbouring countries such Uganda and Congo. Most of these migrants cited the lack of opportunities, forced labour and physical abuse, mostly at the hands of their Tutsi local chiefs, but mandated and approved by the colonial regime. "I left because in Rwanda a man and his wife have to work from 
early morning to late at night for his chief," one migrant is quoted as saying, with another simply stating that he left because he "wanted a job without beatings" (Mamdani, 2001, pp. 110-111). Not surprisingly, the more Hutu frustration increased, the higher their resentment for the Tutsi surged:

The Hutu, deprived of all political power and materially exploited by both the whites and Tutsi, were told by everyone that they were inferiors and deserved their fate and also came to believe it. As a consequence, they began to hate all Tutsi, even those who were just as poor as they, since all Tutsi were members of the 'superior race', something which was to translate itself into the post-second World War vocabulary as feudal exploiters... The time bomb has been set and it was now only a question of when it would go off (Prunier, 1995, p. 39).

Then the 1950s arrived and much of Africa started agitating for the end of colonialism. In most countries, it was a straightforward contest of "us" (native, black) versus "them" (foreign, white), with the natives insisting that the foreigners should pack up and leave. But in Rwanda, things were rather more complicated and the quest for independence took two forms.

On one hand, it was the Tutsi elite demanding the reins of power from their partners in the colonial enterprise and on the other hand, it was the Hutu insisting on the absolute liquidation of the colonial venture, with the return of both the Tutsi and the white colonialists to wherever it was they had come from. It must be noted that even before the push for the end of colonialism began, a new breed of colonial administrators and Catholic clerics, who had been actively questioning what they saw as the unjust subjugation of the Hutu, had started arriving in Rwanda. They could not fathom why a minority Tutsi elite wielded so much power in the country and they demanded change, even though they didn't know exactly how to reverse the order of power.

The divisiveness of the independence struggle, with the majority Hutu on one side and the minority Tutsi on the other, provided the perfect excuse to strip the Tutsi of the power and privilege they had wielded for decades and hand it all to the Hutu. After all, they were the 
majority, the colonialists reckoned. Independence from colonialism became known as "the social revolution" (Prunier, 1995, p. 50; Mamdani, 2003, pp. 103-132). Even though it was signed, sealed and delivered through a series of elections in which the Hutu majority, unsurprisingly, overwhelmingly voted their kith and kin into various positions of local and national authority, it was not an entirely peaceful revolution.

A "false news" report about the death of a Hutu leader who had been attacked by Tutsi activists threw Rwanda into a violent spasm in November 1959. "Many Tutsi houses were burnt, without making a distinction between the high-lineage Tutsi and the ordinary petits Tutsi" (Prunier, 1995, pp. 48-49). By the time the revolution was complete, thousands of Tutsi had fled the country into neighbouring countries like Uganda and present-day Democratic Republic of Congo. But Belgium was not disappointed or worried by this outcome. "It was without doubt the will to give the people back their dignity," the man who supervised the "ethnic transfer of power" in 1959, the Belgian Colonel Guy Logiest, explained some years later. "It was probably just as much the desire to put down the morgue and expose the duplicity of a basically oppressive and unjust aristocracy" (quoted in Prunier, 1995, p. 49).

There were those, however, who were determined to fight to reverse the new Hutudominated order in Rwanda. From their bases outside the country's borders, they launched armed raids in an attempt to destabilize the country and restore the Tutsi monarchy. "From 1959 to 1964, the centre of gravity of Tutsi politics shifted from home to exile, as did the mode of its opposition from political to armed struggle" (Mamdani, 2001, p. 127). The Tutsi population that had stayed behind tended to pay dearly for this new strategy, with the cycle of attack and reprisal forcing many more of their number to seek refuge outside Rwanda: 
A raid turned into a signal for the massacre of the local Tutsi population, and for the distribution of their property among those organized as the local self defense group. Worse than anything that had happened during the revolution, repression joined political violence to redistribution of property, rewarding perpetrators with benefits (Mamdani, 2001, p. 129).

The most serious case of these acts of violence against Tutsi as reprisal for guerrilla attacks by their kin from outside occurred in 1963. It was an audacious attack in which the guerrillas (who called themselves inyenzi or "cockroaches") came within a few miles of the capital, Kigali. The recently organized Rwandan army couldn't hold its lines and it was only with Belgian military backing that the Tutsi guerrillas were pushed back to their bases in the south of Burundi:

Not content with this victory, the government declared a state of emergency to combat "counterrevolutionaries," and designated a minister to organize Hutu "self-defense" units, tasked with the work of "clearing the bush." That meant murdering Tutsi and destroying their homes... Many of the Tutsi who survived followed the earlier swarms of refugees into exile; by mid-1964 as many as a quarter [of a] million Tutsi had fled the country. The British philosopher, Sir Bertrand Russell described the scene in Rwanda "as the most horrible and systematic massacre we have had occasion to witness since the extermination of the Jews by the Nazis.” (Gourevitch, 1998, pp. 64-65).

Some described these violent attacks on Tutsi from 1963 as a "genocide" (Gourevitch, 1998, p.

65), but even if the world didn't see it as such, it seemed either genocide was on some Hutu minds or some Hutu eyes wanted to see the so-called "Tutsi aliens" completely out of Rwanda. A clear message had been sent and the Tutsi took notice. Tutsi were gradually forced into a situation where they were regarded, at best, as second-class citizens or, at worst, as aliens who had no right to exercise any form of political authority over their Hutu "hosts." "After 1964, Tutsi presence was forcibly removed from the political arena; the Tutsi were found in education, in business, in the church, even in government employment, but not in the political arena," Mamdani points out. “The political sphere was [reserved for] the Hutu” (Mamdani, 2001, p. 134). The Hamitic hypothesis had been turned upside down under the banner of "Hutu power" (Mamdani, 2001, p. 
127) - the rule of the majority for (mainly) the majority. The supposedly inferior majority had suddenly discovered superiority in its sheer numbers. It meant not only putting Hutu in charge of whatever needed to be taken charge of, but also making sure that the bulk of whatever social provision the state could make went to the Hutu. Here as well, education was a key area where discrimination was rife, this time against the Tutsi. Under Belgian rule, there were separate school systems for Hutu and Tutsi, but under "majority" rule quotas were set such that most classroom space would go to Hutu. Tutsi could only take whatever was left, and it all had to be proportional to their representation in the general population. If the government data said the Tutsi made up 17 per cent of the population, they could not occupy more than 17 per cent of the classroom spots in any school. Similar quotas were set for employment and other social services.

"Vigilante committees were organised and between October 1972 and February 1973, they scrutinized the schools, the University, the civil service and even private businesses to make sure that the ethnic quota policy was being respected," according to Prunier. "Those most eager to carry out this 'purification' through the vigilante committees were educated people who could expect to benefit from kicking the Tutsi out of their jobs” (Prunier, 1995, p. 60).

Despite all these measures, many were beginning to feel that the "social revolution" had not delivered much of what it promised and there was increased agitation for the government to do more for those in whose name the revolution came into being - the Hutu:

The agitation expanded in concentric circles. Just as it had begun in educational institutions and moved into ministries and enterprises, it grew by ripple effect, with each ripple bringing into the fold yet another tension in Rwandan society. The paralysis of power brought to surface the tension both within power and within society: the former between Hutu of the north and those of the south, and the latter between the poor and the rich (Mamdani, 2001, p. 137). 
These were perfect conditions for the revolution to be given fresh impetus and an army officer, Major General Juvénal Habyarimana, cunningly stepped forward to get the job done. It was an almost bloodless coup d'etat in which the man credited with leading the "social revolution," Grégoire Kayibanda, was arrested and thrown in jail. Habyarimana, who according to Gourevitch, had been "in charge of the [Tutsi] pogroms" sought a rapprochement with the minority group, preaching peace, unity and development. "The message was clear: the violence had served its purpose, and Habyarimana was the fulfilment of the revolution" (Gourevitch, 1998, p. 69). Habyarimana, who gave birth to what became known as "the second Republic" (Mamdani, 2001, p. 133), set out on a near-impossible mission to help the Hutu reap the benefits of the social revolution while seeking, simultaneously, to reconcile them with the Tutsi. The first step toward this objective was to move Rwanda away from the "aliens" and "locals" categorization of Tutsi and Hutu respectively to a recognition of the two identities as distinct ethnic groups, both indigenous to Rwanda. Thus, rejecting the theory of Tutsi as an invading alien race, the government encouraged the two groups to see themselves as ethnic neighbours who had lived side by side for centuries. The second step was to boost the regime of quotas in both education and employment, with the majority Hutu entitled to the majority of available positions. Thus Habyarimana modified and maintained the system in which:

The Tutsi faced discrimination, not just in the political sphere, but in the civic sphere, too. From the point of view of the Second Republic, the Tutsi were not just any minority, but a historically privileged one. As a minority defined statutorily and identified legally, its participation in civil and political life was regulated by state policy. The regulation had two purposes: (1) to redistribute through affirmative state action and (2) to limit participation. The Second Republic followed a "national" goal and sought to arrive at a balance between two tensionridden objectives: justice and reconciliation. Reconciliation with the Tutsi was to be in the context of justice for the Hutu (Mamdani, 2001, p. 138). 
It wasn't the best system, but under the circumstances and for nearly 20 years, everyone seemed to take what they could without much complaining - at least not from within the country. What was there to complain about anyway? The Tutsi were quietly going about whatever their business was, taking great care to "stay away from topics that threaten to flush feelings from their hiding places" (Mushikiwabo, 2003, p. 104), their kith and kin in exile (represented by the guerrillas who called themselves “inyenzi” - or cockroaches) hadn't staged any raids in years and the economy was booming:

[Rwanda] had come a long way from 1976, when it had a per capita income less than that of any of its neighbours. By 1990 the World Bank estimated that the per capita income of Rwanda was higher than that of any of its neighbours. By 1987, Rwanda had the lowest debt, the lowest inflation rate, and the highest rate of growth of the Gross National Product (GNP) of any country in the region... The rate of mortality was down. Hygiene and medical care indicators were improving. The proportion of children in school had gone up from 49.5 percent in 1978 to 61.8 percent in 1986. There had been no political executions since 1982, and there were fewer political prisoners than in most African countries. The record was impressive (Mamdani, 2001, pp. 144-145).

There were, however, undercurrents that didn't feature much on the economic and demographic data sheets. They were mostly coming from the teeming Rwandan refugees, mostly Tutsi and their offspring, who had fled the country to escape the violence that accompanied the social revolution. Dispersed around the world, they kept in touch with each other and formed various groups to represent their interests, including the demand that they be allowed to return to Rwanda peacefully. But the government refused, citing "economic problems linked with their [proposed] return, such as overpopulation, overgrazing or soil erosion" (Prunier, 1995, p. 66). In other words, tiny Rwanda was full and couldn't take in anymore of its own citizens.

This excuse was rejected by the refugees, who were beginning to feel that they had outlived their welcome in foreign lands. In Uganda, in particular, public anger was rising against 
the appointment of some of these refugees (including current Rwandan President Paul Kagame) to the highest ranks in both the Ugandan military and government, as well as the large number of refugees of Rwandan descent, who had been recruited into the army.

With the government in Rwanda refusing the refugees and their offspring the right of return, Mamdani says, these people "found themselves between the Rwandan devil and the Ugandan deep blue sea" (2001, p. 184). They decided that if a peaceful return was impossible, they had no other option than to fight their way back into Rwanda. In October 1990, they launched their first incursions into Rwanda under the banner of the Rwandan Patriotic Front, with "active support from the Ugandan state” (Mamdani, 2001, p. 183).

The outbreak of a civil war between a largely Hutu national army on the one hand and a mainly Tutsi rebel guerrilla formation on the other, reignited the ideologies of Hutu as "locals" and Tutsi as "aliens," with suggestions that the aliens were trying to seize power again - this time, by force of arms - in order to push the locals, once again, into absolute subjugation. After almost 20 years of dormancy, the likes of Léon Mugesera used the civil war to breathe new life into the Hamitic hypothesis. The beastly ideology would cause more damage and claim more lives than ever by turning ordinary people into the relentless killers of nearly a million in a genocidal rampage.

Rwanda would be brought to its knees and from that moment on, as Mark Frohardt, an aid worker would say, "everything you do in Rwanda has to be done in the context of the genocide" (quoted in Gourevitch, 1998, p. 206). In other words, the genocide changed everything in Rwanda, including its media. No examination of the media in that country would be complete if it is undertaken outside of the context of the genocide and the media's complicity in this grave crime against humanity. 


\section{Chapter 3}

\section{LIES AND ILLUSIONS}

Hassan Ngeze was a toddler, learning to take his first steps in life when the "Social Revolution" swept Rwanda. Unlike his parents, Ngeze never suffered any form of subjugation under Tutsi minority rule. But in middle age, working as a newspaper editor, Ngeze published an article claiming that "since the revolution of 1959, the [Tutsi] have not for one moment relinquished the notion of reconquering power in Rwanda, of exterminating intellectuals and dominating [Hutu] farmers" (quoted in Kabanda, 2007, p. 64).

Clearly, as he grew up, Ngeze - like every Rwandan Hutu child - heard from the older folk about how the "alien" Tutsi had come from somewhere to oppress the Hutu and how the Hutu had managed to valiantly redeem their freedom and dignity with the "Social Revolution" of 1959. "In the evening, [a bottle of beer] in hand, [our elders] called the Tutsi weaklings, too high and mighty," one convicted genocidal killer told the French journalist, Jean Hatzfeld. "So Hutu children grew up asking no questions, listening to all this nastiness about Tutsi” (2005, p. 216). After 1959, therefore, the "Hamitic hypothesis" and the racial poison it injected into Rwandan minds became part of the nation's folklore.

Ngeze's generation on the Hutu side grew up, according to another convicted killer in the genocide, "with a natural jealousy" (Hatzefeld, 2005, p. 219) of the Tutsi. The overarching message in it all was that this generation must see itself not only as children of the revolution and its first beneficiaries, but also as the first generation charged with the obligation of defending and promoting the main pillar of the revolution: the idea that the Hutu must remain eternally liberated from Tutsi domination. It was an obligation Hassan Ngeze, described as "a relatively uneducated man” (Melvern, 2006, p. 50), would take seriously, leading him eventually to call on his Hutu kith 
and kin to be "firm and vigilant against their common Tutsi enemy" (quoted in Kinzer, 2008, p. 94), even if this meant committing murder and other atrocities. His words earned Ngeze an infamous place in Rwandan history and a sentence of life imprisonment for inciting hatred.

Ngeze's role in the Rwandan genocide begins with him struggling to earn a living, holding down two jobs - one as a bus conductor, the other as some sort of pub owner, selling beer and assorted drinks near a gas station in the township of Gisenyi. Ngeze was a "small-time hustler" (Gourevitch, 1998, p. 85), biding his time and waiting for his big break, which came with his appointment as a newspaper correspondent, despite his lack of credentials. Though he lacked the requisite education and training, his interactions with everyday folk from his position as a retailer and bus conductor made him the perfect "man-on-the-street correspondent," according to Gourevitch (ibid.). It was a job he did as best as he could until Rwanda was thrown into a state of war, with the Tutsi-led Rwandan Patriotic Front staging an "armed repatriation of [Tutsi] refugees from Uganda" (Mamdani, 2003, p. 184). The war broke out shortly after the Habyarimana regime, under pressure from the international community, decided to end its one-party domination of the Rwandan state by opening up the political space for multi-party democracy:

The great paradox of Rwanda of the 1990s is that democratic reforms blossomed at the same time as the civil war raged. The former fed aspirations for individual and group freedom, the latter gave rise to demands for loyalty to the [Hutu] nation. The two processes could not continue side by side, except through generating tension (Mamdani, 2003, p. 208).

As the war raged, Habyarimana found himself surrounded, constrained and, to all intents and purposes, controlled by a coterie of hardliners from his home region. This was a group made up of hardline Hutu extremists who were in no mood to even contemplate the possibility of relinquishing power to fellow Hutu, much less to an invading Tutsi army. This group was known as the Akazu and was reportedly led by none other than the president's wife, Agathe 
Habyarimana. The Akazu comprised of "a knot of northwesterners [who] had by the late 1980s turned the Rwandan state into little more than an instrument of their will - and with time the president himself stood more as a product of regional power than its source," according to Gourevitch. "When the president [acted against the will of] the Akazu he was quickly set straight" (Gourevitch, pp. 76-77; 81).

It was the Akazu that gave Ngeze his most important job by plucking him from the streets and placing him in charge of the Kangura newspaper. This tabloid was set up to serve as a rival publication to Kanguka, the newspaper which had given Ngeze his first news job. Kanguka had become critical of the Habyarimana regime and the Akazu wanted to curtail its growing influence. However, according to Gourevitch, Ngeze's “irreverent tone” in the new publication "was a bit too much like [Kanguka's] for the tastes of the Akazu, and it annoyed Ngeze's sponsors that he devoted large portions of the first issues to photo-essays extolling his own virtues" (1998, p. 86). Then an opportunity presented itself for the Akazu to haul Ngeze into line:

In July of 1990, when Habyarimana's security forces arrested the editor of Kanguka on charges of high treason, they made a show of balance by simultaneously jailing Hassan Ngeze for disturbing public order. The ploy worked on several levels. Western human rights groups like Amnesty International issued joint appeals for the release of the two editors, bestowing on Ngeze an aura of antiestablishment martyrdom, when the truth was that he was a propagandist of the regime who had disappointed his patrons. At the same time, prison taught Ngeze that his welfare depended on his being a more diligent flunky, and he was an ambitious man who took the lesson to heart (Gourevitch, 1998, p. 86).

When Ngeze was eventually released, the civil war with the RPF, described as "probably the best guerrilla force the world had ever seen” (Prunier, 1995, p. 117), was not going so well from a regime perspective. To add to the regime's troubles, the ranks of Rwanda's Hutu population were divided into those perceived as being on the side of the government and those who had joined the political opposition in demanding change, the so-called rebel "accomplices" or ibiyitso (Prunier, 
1995, p. 121). Ngeze set out to help the regime resolve both issues. Through his writings, he "harangued Hutu to unite behind the president in the struggle against the Tutsi menace" and even occasionally went so far as criticising the president "for failing to lead the struggle with sufficient diligence" (Gourevitch, 1998, p. 86).

At this stage, the government was practically engaged in two wars: a military conflict with perceived Tutsi enemies on one front and a civilian political struggle with both Hutu and Tutsi on another. The regime needed every type of weapon it could lay it hands on to be able to win on both fronts. There was no point winning on one front and losing on the other. The military conflict and the civilian political struggle were intertwined - if the government lost the military battle, it wouldn't have the life to fight in the political arena and if it won in the political arena, it would still have to come up with the energy to continue fighting to win on the military front, where things were not really going so well.

After almost 20 years in power, the Habyarimana regime was facing the prospect of losing power for the first time, but it was not going to give it up without a fight. The best strategy the regime could muster, however, was to link both its military adversaries and political opponents as a collective bunch of public enemies whose primary objective was to topple the "Hutu nation" and return Rwanda to Tutsi domination, which, in their minds - heavily poisoned with large doses of the "Hamitic hypothesis" - would surely be accompanied by Hutu subjugation. "As war intensified and defeat loomed on the horizon, more and more of those in power and even those in the population, came to see dissent not only as a luxury but, at a time of national crisis, as betrayal" (Mamdani, 2003, p. 208).

This meant that all Tutsi were "enemies of the state" (Pillay, Møse and Gunawardana, 2003, p. 295) as were those Hutu who held back their support from the regime and the party 
which represented it. With the "enemy" so broadly defined, the government decided to dredge up an old ideology to bolster its position. This was the ideology of Tutsi as aliens, Hutu as locals, and all the fears of domination and subjugation this ideology provoked among the Hutu. A government minister even went as far as making an open declaration that an RPF victory would amount to "a reversal of history" and lead to "forced labour and feudal servitude" (quoted in Mamdani, 2001, p. 189).

Each member of the Hutu population, therefore, had to decide whether they would support the government to protect the nation from the alleged Tutsi onslaught or side with the perceived Tutsi nation-wreckers, supposedly intent on dominating the Hutu once again:

The RPF invasion offered the Hayarimana oligarchy its best weapon yet against pluralism: the unifying specter of a common enemy. Following the logic of the state ideology - that identity equals politics and politics equals identity - all Tutsi were considered to be RPF "accomplices," and Hutu who failed to subscribe to this view were counted as Tutsi-loving traitors (Gourevitch, 1998, p. 83).

For his part, Prunier points out that the Tutsi were seen as “ontological ibyitso, 'accomplices' of the RPF, and this [was] even in the case of people who had absolutely no sympathy with the guerrillas." Hutu who had joined opposition parties were also deemed “objective ibyitso, no better than Tutsi” (Prunier, 1995, p. 231).

There was no middle ground. Anyone who was not for the regime was seen as being against the Hutu nation, and, consequently, in support of those who wanted to undo the "Social Revolution." That was the message the regime wanted to send out. One of its first messengers was Hassan Ngeze, whose newspaper's operating expenses "were defrayed by government credit" (Gourevitch, 1998, pp. 86-87). This newspaper became "well known for its hysterical hatred of Tutsi and any Hutu who expressed a desire for change, freedom and democratic openness" (Kabanda, 2007, p. 62). Ngeze would become one of the regime's foot soldiers, his words were his 
weapons and he would unleash them to deadly effect, urging his Hutu kin to have nothing to do with the Tutsi, except, perhaps, helping Rwanda to get rid of them. "In a few swift strokes [of his pen], Ngeze revived, revised, and reconciled the Hamitic myth and the rhetoric of the Hutu revolution to articulate a doctrine of militant Hutu purity" (Gourevitch, 1998, p. 88). Pillay et al point out that Ngeze's writings:

Portrayed the Tutsi as inherently wicked and ambitious in language clearly intended to fan the flames of resentment and anger, directed against the Tutsi population. The cover of Kangura No. 26 answered the question 'what weapons shall we use to conquer the Inyenzi once and for all?' with the depiction of a machete. The message conveyed by this cover was a message of violence, that the machete should be used to conquer the Inyenzi once and for all. By Inyenzi, Kangura meant, and was understood to mean, all Rwandans of Tutsi ethnicity, who in this issue of Kangura were stereotyped as having inherent characteristics of liars, thieves and killers (Pillay et al, 2003, p. 281).

Kangura No. 26, however, was not the worst of Ngeze's venom of anti-Tutsi propaganda. In his most cited piece of vitriolic bigotry, Ngeze wrote what he called the Hutu Ten Commandments in an article entitled Appeal to the conscience of the Hutu. In this article, Ngeze denounced the Tutsi and spelled out why Rwanda was better off without their presence. "The Tutsi are bloodthirsty and power-mad and they want to impose their hegemony over the Rwandan people at gunpoint," he wrote, the reference to "the Rwandan people" a subtle suggestion that the Tutsi were not Rwandan (quoted in Frère, 2007, p. 89). In the eighth commandment, Ngeze proclaimed that "the [Hutu] must no longer have pity on the [Tutsi]" (quoted in Frère, 2007, p. 90). Gourevitch points out that:

According to Ngeze's protocols, all Tutsi women were Tutsi agents; Hutu men who married, befriended, or employed a Tutsi woman "as a secretary or concubine" were to be considered traitors, and Hutu women, for their part, were commanded to guard against the Tutsi-loving impulses of Hutu men. From sex, Ngeze moved on to matters of business, declaring every Tutsi dishonest - "his only aim is the supremacy of his ethnic group" - and any Hutu who had financial dealings with Tutsi an enemy of his people. The same held for political life; Hutu 
should control "all strategic positions, political, administrative, economic, military, and security." Hutu were further commanded to have "unity and solidarity" against "their common Tutsi enemy," to study and spread "the Hutu ideology" of the revolution of 1959, and to regard as a traitor any Hutu who "persecutes his brother Hutu” for studying or spreading the ideology (Gourevitch, 1998, p. 88).

The publication of the Hutu Ten Commandments marked a significant escalation in the government's strategy of using words as weapons against both the armed and unarmed opposition. It was classic "propaganda," a word which appears frequently in almost all the literature on the Rwandan genocide. Philip Taylor defines propaganda as:

The communication of ideas designed to persuade people to think and behave in a desired way. It differs - or should do - from education in that the imparting of the information and ideas for educational purposes is to enable the recipient to make up his or her own mind on any given issue. Propaganda is about persuading people to do things which benefit those doing the persuading, either directly or indirectly. In wartime that usually means getting them to fight or to support the fight (Taylor, 2003, p. 6).

In Rwanda before the genocide, the government adopted small-scale propaganda tactics after the RPF launched its first attacks, ratcheting up the propaganda (with Ngeze as one of its chief purveyors) as it appeared to be facing military defeat. Des Forges mentions a document, in which an unnamed propagandist, "obviously someone who had studied at university level... advocates using lies, exaggeration, ridicule, and innuendo to attack the opponent, in both his private and public life:"

The propagandist proposes two techniques that were to become often used in Rwanda. The first is to "create" events to lend credence to propaganda... The propagandist calls his second proposal "accusation in a mirror," meaning his colleagues should impute to enemies exactly what they and their own party are planning to do... There is no proof that officials and propagandists who "created" events and made "allegations in the mirror" were familiar with this particular document, but they regularly used the techniques that it described (Des Forges, 1999, p. 57). 
When Ngeze's Kangura started spewing ethnic venom, with the blessing and support of regime hardliners, he was doing more to cause public disorder than when he was jailed in the media clampdown mentioned earlier, but no attempts were made to arrest him this time. This was because he was playing his part in the war effort and Frère even suggests that "majority of articles in Kangura came directly from the presidency, the Central Intelligence Service or the Akazu" (Frère, 2007, p. 83).

It can be discerned at this point that Ngeze was, in the eyes of his paymasters, doing an excellent job as a propagandist who had adorned himself in the cloak of a journalist, his propaganda falsely packaged as journalism. This distinction is important because it provides the backdrop for the subsequent discussion and analyses of the Rwandan media's alleged complicity in the genocide.

As pleasing as Ngeze's publication was to his paymasters, the Akazu soon realized that "the paper lacked two important elements to be truly effective: a popular tone, and the capacity to reach a large public" (Frère, 2007, p. 90). In Kangura, the Akazu found an outlet for its message of hate, but as the stakes kept rising, the group agreed that the message was not going far enough. The message needed to be amplified to reach everyone on Rwanda's thousand hills. The Akazu, therefore, decided to build itself a radio station.

It is noteworthy that the decision to acquire a radio station was taken at a time when internationally mediated negotiations were underway to broker an end to the civil war. These negotiations had resulted in significant concessions from the government for power-sharing, concessions the Akazu didn't take kindly to. "Each time there was a concession towards power sharing there was violence, and it was aimed not just at the political opposition but against the Tutsi," Melvern points out. "Violence for political ends was now a part of political life in 
Rwanda” (Melvern, 2006, p. 25). Much of this violence was carried out by hardline civilian militia groups, sponsored by Hutu-affiliated political parties. The most active and feared militia groupings were the Impuzamugambi of the CDR party - which "promoted the most anti-Tutsi policies and banned from its membership anyone with Tutsi grandparents" (Melvern, 2006, p. 51) - and the Interahamwe of the ruling MRND party:

Members of the Interahamwe were given military training: witnesses from Camp Kigali, an army base in the heart of the city, saw government buses turning up at the barracks in 1992, carrying certain soldiers to secret places where they would train the unemployed. The recruits were initially trained to handle weapons and use explosives and then later they were taught to kill, with emphasis on killing at speed (Melvern, 2006, p. 26).

The Interabamwe were a constant feature "at a lot of political rallies dressed rather bizarrely, in cotton combat fatigues covered in fantastical symbols in the red, green and black of the Rwandan flag and carrying machetes or carved replicas of Kalashnikovs," according to Roméo Dallaire, who was commanding the United Nation's peacekeeping force in Rwanda at the time. "We had found them comical at first, because they looked and acted like clowns, but we soon learned that wherever they showed up, violence and mayhem were never far behind" (Dallaire, 2003, p. 129).

It was in this atmosphere of civil war and wanton violence against civilians - coupled with political campaigning and negotiations towards bringing the civil war to an end - that the Akazu decided it needed a radio station to further spread and amplify its doctrine of hate. Radio, it reckoned, was going to be a vital instrument towards what the $A$ kazu considered to be the "big clean up," the "final solution" (Prunier, 1995, p. 200) and apocalypse deux (Melvern, 2006, p. 41).

The decision by the Akazu to open and run a radio station of its own appears to have been influenced largely by political pressure and what the Akazu might have considered to be the demographic imperative to draw in more people - the younger the better - to buy into its agenda 
for the so-called "final solution." The "official tone" (Frère, 2007, p. 96) of the state-run Radio Rwanda was not quite cutting it, even though this station was already under the thumb of the regime and had, indeed, been used to implement the propaganda techniques of creating events and making "accusations in the mirror" (Des Forges, 1999, p. 57). An example of this was the “faked news" report (Melvern, 2006, p. 42) “in early March 1992, when the state-owned Radio Rwanda announced the "discovery" of a Tutsi plan to massacre Hutu," according to Gourevitch. "This was misinformation, but in pre-emptive "self defense" [Interahamwe] militia members and villagers in the Bugesera region, south of Kigali, slaughtered three hundred Tutsi in three days (Gourevitch, 1998, p. 94). Besides its “staid” programming format (Straus, 2007, p. 612) Radio Rwanda also employed a significant number of highly trained journalists who were determined to stand by their professional principles and thus resisted the regime's attempts to turn them into mere propagandists. Prunier suggests that "Radio Rwanda reporters, feeling that change was in the air, were beginning to show a sense of independence and to report what was actually going on, even if the news they carried was not particularly favourable to the regime" (Prunier, 1995, p. 164).

In a further sign that Radio Rwanda was slipping out of the hands of the Akazu, political pressure compelled the government to appoint an opposition figure to the helm of the station "to steer [it] towards a more non-partisan stance” (Des Forges, 1999, pp. 58-59). A media rights NGO, Article 19, also point out that "the idea of creating an independent radio station, devoted entirely to the agenda of the extremists within the [ruling party], appears to have arisen in response to reforms at Radio Rwanda, which had been under pressure from opposition parties to grant them access since late 1991" (Article 19, 1996, p. 40). 
Completing the list of reasons why the Akazu needed a radio network for itself was the fact that the RPF was operating its own station, Radio Muhabura. Transmitting from Uganda, this rebel-run network attracted a significant number of people, who used to secretly listen to its programs, because "being discovered listening to Radio Muhabura was sufficient to be considered an "accomplice" of the RPF" (Frère, 2007, p. 86).

The radio station the Akaz $u$ built for itself not only resolved all these issues, but also coordinated the group's propaganda efforts and increased its reach. The Akazu station, known as Radio-Télévision Libres des Mille Collines (RTLM), "did not provide factual news reports or engage in standard journalistic activities such as reporting items of public interest or conducting field investigations," according to the NGO, Article 19. "Instead, they presented informal and unstructured commentaries on various subjects, usually in the form of dialogues and relied heavily on lengthy interviews with guests to fill airtime (Article 19, 1996, p. 49) For his part, Gourevitch, describes RTLM, which started broadcasting in July 1993, as "a Kangura of the airwaves" (Gourevitch, 1998, p. 99). The station "was lively, amusing, and a clear departure from the official tone of Radio Rwanda and Radio Muhabura," Frère points out. "Relayed rapidly across the whole of the country, it reached a large part of the rural and illiterate masses, who did not have access to the written press but possessed small, cheap transistor radios" (Frère, 2007, p. 90).

RTLM's broadcasts took the government's ethnic and hate-filled propaganda to levels never before seen (or heard) in Africa and definitely not in the world since the Nazi regime in Germany in the 1930s. The Akazu appeared to have learned a lesson or two from the Nazi's chief propagandist, Joseph Goebbels, who conceded in 1933 that "it would not have been possible for us [the Nazis] to take power or to use it in the ways we have without the radio and the airplane," stressing that: 
A radio that does not seek to deal with the problems of the day does not deserve to influence the broad masses. It will soon become an empty playground for technicians and intellectual experimenters. We live in the age of the masses; the masses rightly demand that they participate in the great events of the day. The radio is the most influential and important intermediary between a spiritual movement and the nation, between the idea and the people (Goebbels, 1933, August 18).

So sophisticated was the extremist radio propaganda in Rwanda from July 1993 that it led JeanPierre Chrétien to characterize it as "a well thought-out and ably executed propaganda, no improvised harangues of rabid fringe elements, but a breviary of hate, carefully distilled by professionals in the audio-visual fields" (quoted in Frère, 2007, pp. 90-91). Among the professionals behind RTLM was Ferdinand Nahimana, "a renowned academic" (Pillay et al, 2003, p. 305) who had just been forced out of his position as the head of Office Rwandais d'Information (ORINFOR), the government agency with oversight responsibility for Radio Rwanda. Pillay et al point out that it was Nahimana, as head of ORINFOR, who had ordered the broadcast of the fake news item, based on a communiqué from Nairobi, which led to the killings in the Bugesera region in March 1992 (mentioned above):

The editorial team had decided not to broadcast the communiqué because of their inability to confirm its authenticity. This decision was reversed by Nahimana, who by his own admission did not make an effort to ascertain the accuracy of the Radio Rwanda broadcast, which spread fear and provoked violence against the Tutsi population by Hutu who were falsely led to believe that they faced imminent attack (Pillay et al, 2003, p. 286).

At RTLM, Nahimana, as one of three directors of the station, "played an active role in determining the content of station's broadcasts, writing editorials and giving journalists texts to read" (Pillay et al, 2003, p. 284). Right from its first transmission, most Rwandans came to believe that the station was up to no good:

In its presentation and format, RTLM essentially resembled and probably modelled itself after Western-style radio talk shows complete with audience 
participation, offensive jokes and popular music. In a country where both official media and the rebel radio station were notoriously formal, the more entertaining RTLM faced no serious competition. [The station] was listened to by a wide section of Kigali's population, including office workers during working hours. Outside of Kigali and other urban centres, the station is reported to have attracted people from urban backgrounds, administrators and teachers, rather than peasants from rural areas (Article 19, 1996, p. 49).

Much of the anti-Tutsi virulence on RTLM started after President Habyarimana made some farreaching power-sharing concessions at the negotiation table, signing off on what has become known as the Arusha Accords (named for the Tanzanian capital, where they were brokered and signed). This didn't go down well with the extremists who "cried treason, and charged that the president himself had become an accomplice” (Gourevitch, 1998, p. 99).

RTLM's rabid and hate-filled broadcasts increased dramatically after the assassination of the Hutu president of neighbouring Burundi, Melchoir Ndadaye, by Tutsi soldiers of the Burundian army. Following the death of Ndadaye, the station "became immersed in politics, arguing that the generalized violence that had reigned in the neighbouring country could spread to Rwanda" (Frère, 2007, p. 86). According to Des Forges, "RTLM reported the assassination of the Burundi president in a highly sensationalized way to underline the supposed Tutsi brutality and heighten Hutu fears of Tutsi (Des Forges, 2007, p. 45). Article 19, the NGO, also points out that:

Although short of accurate information, RTLM announcers did not hesitate to draw sweeping conclusions in their commentaries on Burundi. The station tried to instil panic and fear by presenting events in Burundi as a threat to internal security in Rwanda and called on listeners to intervene "on behalf' of the Hutu in Burundi, claiming that the violence could soon spread to Rwanda (Article 19, 1996, p. 52).

The death of the Burundian president also made RTLM's denunciation of the Arusha Accords louder and more vehement, with the station particularly targeting General Roméo Dallaire, the Canadian commander of the United Nation's peacekeeping force which had been deployed in the country as part of the peace agreement. Dallaire complained about this and Nahimana made a 
“successful intervention" to "stop RTLM attacks" on the UN force and its commander (Pillay et al, 2003, p. 296). Others, less important but more hated, were not so lucky, though, to be spared from the station's on-air “persecution” (Pillay et al, 2003, p. 302). People (Hutu and Tutsi alike) who were named as RPF “accomplices” on the airwaves were often violently attacked by militia and, in some cases, murdered - even before the genocide. "The mention of someone's name [in a broadcast] was almost a sentence to death" (Monasebian, 2007, p. 318). RTLM, therefore, added the regular naming of so-called "accomplices" to its programming in the months leading up to the genocide:

The list of "accomplices" [the station] broadcast led immediately to the tracking down of opposition Hutu who were favourable to the Arusha Accords, as well as journalists and human rights militants who tried to denounce the violence aimed at the Tutsi. Once a person was identified, the militias created checkpoints in order to search inhabitants of the area where the person lived, and violently attacked all those whose identity cards indicated they were Tutsi (Frère, 2007, p. 91).

When it became clear that RTLM was becoming an instrument for extremist propaganda, the station's key managers were summoned on three different occasions to the office of the information minister, according to Monasebian, for discussions on the flagrant violations of their licensing agreement. But after each of these meetings, the network "responded by targeting, or intensifying its targeting of [officials] who drew attention to its extremist broadcasts" (Monasebian, 2007, p. 310). No firm action was taken against the station and the vile propaganda continued, even worsened. In one instance an RTLM announcer appeared to be mocking a rather chastened information minister who had come to the realization that there was little he could do to stop the hate propaganda on the station:

People told me he has become wise. Our bone of contention was that he wanted to close down RTLM, the people's radio. He probably realized that this was no easy task; he realized that this was like carrying a cross. He has given up and this is no longer one of his topics. Obviously, he reports what his bosses want him to 
say, but he realized that the idea of closing down the people's radio could cause him a lot of trouble, which is why he gave up (quoted in Monasebian, 2007, p. 318).

Western diplomats in Kigali also reportedly took issue with RTLM's broadcasts and complained to President Habyarimana. His response was to point out that "the West had pressured him to move towards democracy, he no longer had the power to control the airwaves; democracies guaranteed free speech” (Melvern, 2006, p. 56). Even Dallaire was so deeply concerned by the vitriol and the "disinformation" that was constantly streaming from the RTLM transmitters, that he made a request to his UN bosses for the station, which, according to him, was "a direct instrument in promoting genocide" to be "shut down... either through jamming, a direct air strike on [its] transmitter, or covert operations" (Dallaire, 2003, pp. $330 \& 375$ ).

Dallaire's request was rejected, of course, and RTLM became even more relentless in its campaign of "ethnic stereotyping in a manner that promoted contempt and hatred for the Tutsi population" (Pillay et al, 2003, p. 292). By now, the network was working very closely with Hassan Ngeze and Kangura. In one instance of their propagandistic collaboration, the radio station and the newspaper launched a joint competition involving a quiz in the newspaper. Readers were directed to submit their answers to the offices of RTLM, which regularly announced the names of winners and their prizes:

[The] competition was a joint undertaking of Kangura and RTLM intended to acquaint the readers of Kangura and the listerners of RTLM with the content and ideas of Kangura as set forth in its past issues... The competition was designed to direct participants to any and all of these issues of the publication and that in this manner in March 1994 Kangura effectively and purposely brought these issues back into circulation (Pillay et al, 2003, p. 281).

As it helped Kangura to revive past issues, RTLM continued with its regular fare of naming alleged Tutsi accomplices, with even more serious allegations that plots were being hatched to assassinate 
President Habyarimana. Among those named as part of this conspiracy was the Hutu prime minister, Agathe Uwilingiyimana, the attorney general, Alphonse Nkubito and other leading political figures. The RTLM announcers openly said Miss Uwilingiyimana was “condemned to die" and warned that "if the president was killed, the Tutsi [will] be exterminated" (Monasebian, 2007, pp. $312 \& 320)$.

When Nkubito tried to file charges against the announcer who mentioned his name as one of those behind the alleged conspiracy to assassinate the president, the announcer told his interrogators that "the only thing he did was to read out a telegram given to him by his superior [Ferdinand] Nahimana" (Melvern, 2006, p. 105).

In Kangura, Ngeze was telling the whole world that the president was going to die in an article also alleging an assassination conspiracy:

An accompanying cartoon depicted the President as a Tutsi-loving RPF accomplice, and the article explained that he would "not be killed by a Tutsi" but by a "Hutu bought by the cockroaches... Kangura proposed [that]... the president [will be] assassinated "during a mass celebration" or "during a meeting with his leaders." The article opened with the words, "nothing happens that we did not predict," and ended, "nobody likes Habyarimana's life better than he does. The important thing is to tell him how he will be killed" (Gourevitch, 1998, pp. 108109).

As the allegations of an assassination plot were being bandied about, there was pressure on the government, and the president in particular, to ensure the full implementation of the Arusha Accords, a process which was well-behind schedule. All throughout the country, meanwhile, "the army was slipping more and more weapons to the Interahamwe and the Impuzamugambi," (Prunier, 1995, p. 184) and there was unease as "rumours were circulating about what was going to happen, about plans, plots and intrigue" (Melvern, 2006, p. 109). Even the European Union had cause to 
issue a public statement urging the various factions to honour their obligations under the Arusha Accords to ensure peace:

The European Union has to express its deep concern about the climate of insecurity which is increasing in the country and particularly in the capital and surrounding areas. It is alarmed at the proliferation of weapons and wishes to point out the unacceptable role of some media which are blocking the indispensable climate of national reconciliation. The European Union reiterates that its support for the peace process will only be effective if the parties speedily implement the provisions of the Arusha Accords (quoted in Prunier, 1994, p. 209).

Under so much pressure from the international community, President Habyarimana made the decision to have a transitional government sworn in upon his return from a summit of regional leaders in Tanzania. At the summit itself, Habyarimana told his counterparts that he would implement the accords. This pledge appears to have gone against the wishes of the Akazu, which was by this time effectively running Rwanda, and had "become convinced that the president was ready to sacrifice their material interests to his future political manoeuvering" (Prunier, 1995, p. 227). The only way to stop the president from going any further, the Akaqu seemingly decided, was to completely take him out of the picture.

On his way back from the summit in Tanzania, Habyarimana and his plane were blown to pieces in mid air as the aircraft was preparing to land at Kigali International Airport. "A Rwandan student officer at the airport who was listening to RTLM heard the announcer say the presidential jet was coming in to land," according Melvern. "Then suddenly and surprisingly, the broadcast stopped and classical music was played” (Melvern, 2006, p. 134). Three days before the crash, according to the NGO, Article 19, the station had announced that the RPF rebels were planning for "a little something in Kigali:"

Like the previous warnings in the press, RTLM claimed that [the rebel group] was planning to violate the ceasefire to overthrow the Rwandan government. "The RPF rebels want to take power. Take it by use of arms. They want to do a little 
something." The broadcaster claimed that his informants [with the rebels] had confirmed dates of the planned invasion. "They tell us [that] on the $3^{\text {rd }}$, the $4^{\text {th }}$ and the $5^{\text {th }}$, there will be a little something here in Kigali City and also on the $7^{\text {th }}$ and $8^{\text {th }}$ you will hear sounds of bullets and grenades explode... But I hope that the Rwandan armed forces are on the alert" (Article 19, 1996, p. 59).

The question of who was behind Habyarimana's assassination has remained unresolved. For many writers, however, Habyarimana's assassination was essentially a coup d'état, wrought by the Akazu to pave the way for the mass killing of Tutsi and moderate (opposition) Hutu. After all, the two Akazu media outlets had both predicted the death of the president, with the radio station in particular, going further to suggest that "something bigger was to follow, the "Simusiga" or the "final attack," according to Article 19, the NGO. "The "Simusiga" or the "final battle" was how RTLM would refer to the genocide as it unfolded over the next three and a half months" (Article 19, 1996, p. 60). Prunier suggests that:

The strongest support for the view that the president's assassination and the ensuing massacres were connected came from the speed with which the situation moved from one to the other. The plane was shot down at around 8.30p.m., and by 9.15 there were already Interahamwe roadblocks everywhere in town and houses were being searched (Prunier, 1995, p. 223).

There is also the little matter of one of the leading members of the Akazu, Colonel Théoneste Bagosora, who would later "coordinate the genocide” (Prunier, 1995, p. 163) calling the UN's special representative in Kigali to say: “Don't worry, this is a coup but everything is under control. We will succeed and save the nation" (quoted in Prunier, 1995, p. 225). Gourevitch also points out that "the road blocks, the confident tone of the RTLM announcers, and the reports of killings in the streets left no doubt that Hutu Power [the public, political face of the Akazu] was conducting a coup d'etat"' (Gourevitch, 1998, p. 113).

But the controversy over who was behind Habyarimana's assassination and whether or not it was a coup d'état is secondary, almost irrelevant, in the context of what occurred after - the 
genocide, starting with the brutal murder of the prime minister, Agathe Uwilingiyimana. As Mamdani points out, "the death of the president and the killing of the prime minister removed precisely those leaders who had publicly championed an agenda for an "ethnic reconciliation" between the Hutu and Tutsi” (Mamdani, 2001, p. 215).

As Gourevitch suggests, "regardless of who killed Habyarimana, the fact remains that the organizers of the genocide were primed to exploit his death instantaneously" (Gourevitch, 1998, p. 113). And as the genocide unfolded, RTLM, Rwanda's first and only privately-owned radio station in 1994, with Théoneste Bagosora as majority shareholder (see Melvern, 2006, p. 56) played four prominent roles, plunging radio broadcasting to new depths of infamy.

First of all RTLM helped to further weaken the already-constrained UN peacekeeping force. The verbal attacks on the UN contingent, which its commander, Dallaire, had complained about to Ferdinand Nahimana, resurfaced with even more venom after Habyarimana's assassination. Announcers, without a scintilla of evidence, blamed the Belgian contingent in the UN force for the plane crash. "Hate radio," according to Dallaire, "had led everyone inside its gates to believe that our Belgians had killed their president," (Dallaire, 2003, p. 241). These broadcasts, it seems, were meant to prepare the minds of the populace for what had been planned for the Belgian component of the U.N force. Shortly after the crash of the president's plane, the Rwandan presidential guard went on the rampage, conducting "an obviously well-organized and well-executed plan - by noon of April 7 the moderate political leadership of Rwanda was dead or in hiding, the potential for a future moderate government utterly lost” (Dallaire, 2003, p. 232).

When they stormed the home of the moderate prime minister and saw Belgian soldiers guarding her, they captured these soldiers, killed the prime minister and much of her family on the spot and later murdered the soldiers in a military camp - all "under the stimulus of [the RTLM] 
broadcasts" (Des Forges, 2007, p. 48). The death of these 10 soldiers, became the main basis for the decision by Belgium (the former colonial power) to withdraw its contingent, leaving Rwanda to its fate. With the withdrawal of the Belgian contingent, the planners of the genocide achieved their major objective of making the world (the Western world especially) too scared to intervene:

The aim was to secure first a Belgian, then a UN withdrawal. The extremists... knew that Western nations do not have the stomach or the will to sustain casualties in peace support operations. When confronted with casualties, as the United States was in Somalia or the Belgians in Rwanda, they will run, regardless of the consequences to the abandoned population (Dallaire, 2003, p. 240).

With the Belgians gone, there was little else the remainder of the UN peacekeeping soldiers could do beyond keeping themselves alive. In the midst of "unimaginable carnage" (Dallaire, 2003, p. 262), the UN's blue berets stood by without a mandate to intervene, listening to the radio like everyone else, watching - like ringside spectators to one of the worst human tragedies of the $20^{\text {th }}$ century - as thousands hacked, bludgeoned and shot their compatriots to death.

RTLM's second role in the genocide saw the station stepping up its campaign of inciting the Hutu against the Tutsi. It is noteworthy that after the assassination of Habyarimana, the director of Radio Rwanda, fearing for his life fled the country, leaving the extremists to do on the public network (albeit on a much smaller scale) what they had been doing on their private station. According to Des Forges, an RTLM announcer was heard saying that "Radio Rwanda had changed from a "rival" to a "sister," (Des Forges, 2007, p. 48).

Be that as it may, in this sisterhood of broadcast infamy, RTLM led the way and it is the one network most often cited as the major media instrument in the Akazu genocidal machinery. This instrument had been used to preach hatred for several months before the assassination of Habyarimana. With the president dead, RTLM's broadcasts became even more venomous and incessant, with the Tutsi being apportioned much of the blame for the president's demise. In 
blaming the Tutsi for the assassination, the message RTLM sent out was that if the Tutsi have killed the president of all the people, what was to stop them from killing the peasants, the lesser Hutu. After leading the Hutu masses to fear that they would be killed by their Tutsi neighbours, RTLM's "chilling broadcasts invited listeners to join in the killing, as if this were an appeal to patriotism” (Mamdani, 2001, p. 212). One presenter was heard taunting the Tutsi: "You cockroaches must know that you are made of flesh. We won't let you kill, we will kill you" (quoted in Gourevitch, 1998, p. 114).

RTLM therefore moved from preaching hatred to actually encouraging the Hutu population to act on their fear of the Tutsi. The message was simple: kill or be killed. Right from the moment the president was confirmed dead, the station "started to broadcast direct incitements to deliberately murder 'to avenge the death of our president'," Prunier points out. 'Within the next few hours the calls turned into hysterical appeals for ever greater quantities of blood (Prunier, 1995, p. 224). According to Article 19:

RTLM indirectly and systematically advocated the killings of Tutsi by identifying them with the [rebel movement] who it claimed had invaded Rwanda, assassinated the president and would exterminate all the Hutu if the supposed attack was not immediately repulsed. [The station] described the genocide as a "final war" or "final battle," claiming the only way to stop the RPF was to exterminate all the rebels and their alleged "accomplices," implying all Tutsi civilians (Article 19, 1996, p. 67).

And Gourevitch reports that:

With the encouragement of such messages and of leaders at every level of society, the slaughter of Tutsi and the assassination of Hutu oppositionists spread from region to region. Following the militia's example, Hutu, young and old rose to the task. Neighbours hacked neighbours to death in their homes and colleagues hacked colleagues to death in their workplaces. Doctors killed their patients, and schoolteachers killed their pupils. Within days the Tutsi populations of many villages were all but eliminated... Radio announcers reminded listeners not to take pity on women and children (Gourevitch, 1998, p. 115). 
On Radio Rwanda around the same time, a "politician" was warning Hutu that the Tutsi were about to "exterminate you until they are the only ones left in the country so that they can keep for a thousand years the power that their fathers had kept for four hundred years... You must not let up in your efforts" (quoted in Des Forges, 2007, p. 48).

RTLM also continued naming people the station deemed to be enemies of the state and therefore, needed to be killed. Pillay et al point out "a pattern of naming people on vague suspicion, without articulated grounds, or in those cases where the grounds were articulated, they were highly speculative or in some cases, entirely unfounded" (Pillay et al, 2003, p. 299). According to Li, "once the genocide began, the naming of places by [RTLM announcers] became associated with exhortations [for militia] to rush to specific areas where there were still Tutsi to be found" (Li, 2007, p. 102). These exhortations placed the station at the very heart of the macabre logistical operation that was the genocide as it:

Was in permanent contact with the militias posted at the barriers and with the night patrols. The radio announcers greeted and encouraged them, urging them to smoke hemp to give them courage and repeating the call to rob and pillage Tutsi property. (Frère, 2007, p. 91).

This, Frère emphasizes, meant that "RTLM was a real actor at the center of events:"

It broadcast information that allowed the militias to organize themselves, to search each district for "accomplices," and to maintain a steady supply of arms. It provided updated lists of people who had already been executed and those who had still not been found. RTLM asked listeners for clues to locate the "accomplices" and told them to contact the station so it could broadcast the addresses where they were hiding; it also broadcast license plate numbers of cars that people were using to try to escape (Frère, 2007, p. 92).

The need to stay in contact with the militia to help with the organization of the massacres saw Hassan Ngeze, the editor of Kangura, drop his pen every once in a while to get behind a 
microphone in the studios of RTLM. In one broadcast, he was heard admonishing the killers to be careful and make sure they are killing the right people. According to Pillay et al:

Ngeze was trying to send a message, or several messages, to those at the roadblocks. One clear message was: do not kill the wrong people, meaning innocent Hutu who might be mistaken for Tutsi because they had Tutsi features, or because they did not have identification (Pillay et al, 2003, p. 287).

Finally, one can also point to the gloating and sheer delight in the voices of RTLM announcers as blood was being spilled in almost every corner of Rwanda as another example of the station's extremism and its role in helping the organization and implementation of the plan of extermination. For example, after announcing the installation of an interim government after the death of Habyarimana (at a time when the massacres were well underway), the broadcaster, Valérie Bemeriki "began to giggle and told her listeners that the opposition members in the previous government could not be found" (Melvern, 2006, p. 175).

In another example, getting to the end of the genocide, with French troops arriving in the country on a so-called "humanitarian" mission, "a disc jockey on RTLM advised Hutu women to gussy themselves up for the white men, taunting, 'now that the Tutsi girls are all dead, it's your chance'," (Gourevitch, 1998, p. 155). And gloating over the killings, Bemeriki, the giggling announcer, admonished the militias: "Do not kill those cockroaches with a bullet - cut them to pieces with a machete" (BBC, 2009, December 14).

Thus, Chretién says, "two tools, one very modern, the other less so, were particularly used during the genocide of the Tutsi in Rwanda: the radio and the machete, the first to give and receive orders, the second to carry them out (quoted in Li, 2007, p. 92). Today, two decades after the genocide, most of those behind RTLM's broadcasts are in jail, convicted either by local Rwandan courts or the UN-mandated International Criminal Tribunal for Rwanda (ICTR), which 
sat in Arusha, Tanzania. In the dock at the so-called ICTR media trial were Ngeze, Nahimana and Jean-Bosco Barayagwiza - respectively, the Akazu lap dog, the "intellectual inspiration for the genocide" (Melvern, 2006, p. 210) and the leading operative of the extremist CDR party (Pillay et al, 2003, p. 282). Among others, they were found guilty of direct and public incitement to genocide and crimes against humanity, with these convictions mostly hinged on their operation and use of RTLM and Kangura. The tribunal ruled that:

The newspaper and the radio explicitly and repeatedly, in fact relentlessly, targeted the Tutsi population for destruction. Demonizing the Tutsi as having inherently evil qualities, equating the ethnic group with the 'enemy' and portraying its women as seductive enemy agents, the media called for the extermination of the Tutsi ethnic group as a response to the political threat that they associated with Tutsi ethnicity (Pillay et al, 2003, p. 294).

This constituted a very serious indictment on the media in Rwanda, a big dent in the reputation of the media in the country. Two decades after the genocide, this blot on the Rwandan media gives many people, especially those in government, a reason to view the media with a lot of suspicion. But despite the tribunal's verdict and its finding of a "specific causal connection" between what people heard on radio and some (not all) of the killings that took place in Rwanda (Pillay et al, 2003, p. 292), there are major gaps in what the world knows about the extent to which the media contributed to (or, some might say, influenced) Rwandans to hack neighbours, friends and perceived enemies to death in the frenzy of almost unprecedented mass murder. And so, the question remains: could there have been a genocide without the hate media outlets of Kangura and RTLM? The next chapter will attempt an answer. 


\section{Chapter 4}

\section{CAUSES AND EFFECTS}

Jean-Baptiste Murangira was one of the few Hutu in Rwanda in 1994 with a Tutsi wife. Such unions were so rare that the French journalist, Jean Hatzfeld, suggests that "many officials and prominent [Hutu] citizens wed Tutsi women for reasons of snobbery" (Hatzfeld, 2005, p. 250). But Murangira insists that he had no ulterior motives for marrying Spéciose Mukandahunga and that his feelings for her were firmly rooted in true love. "I chose my wife for love of her beauty," he says. "She was tall and very considerate" (quoted in Hatzfeld, 2003, p. 23). To prove his affections for Spéciose, Murangira killed a fellow Hutu man to save the life of his Tutsi wife.

The genocide was well underway. Murangira, a farmer, had joined a gang which had been chasing frightened Tutsi through the marshes in the village of Nyamata, south of Kigali. On the way back from one such expedition, the gang came across a Hutu man who had helped some Tutsi escape. The gang wanted the Tutsi-helper killed to send a message that saving a Tutsi life was as risky as being a Tutsi. That was when Murangira, Hutu husband to a Tutsi wife, was forced to kill. It was the murder that would guarantee his spouse's right to live:

I felt great pain to think of losing her... I seized the machete, I struck a first blow. When I saw the blood bubble up, I jumped back a step. Someone blocked me from behind and shoved me forward by both elbows. I closed my eyes in the brouhaha and I delivered a second blow like the first. It was done, people approved, they were satisfied and moved away. I went off to sit on the bench of a small cabaret. I picked up a drink. I never looked back in that unhappy direction. Afterward, I learned the man had kept moving for two long hours before finishing (quoted in Hatzfeld, 2005, p. 23).

It was Murangira's first kill. It wouldn't be his last. With blood on his hands, Murangira had become a full-fledged participant in the genocide. Members of his gang "were all farmers, except for one civil servant and one teacher," according to Hatzfeld. "None of them had ever quarrelled 
with his Tutsi neighbours over land, crops, or women” (Hatzfeld, 2005, p. 45). What, then, made people like Murangira turn on their Tutsi neighbours with such murderous outrage, culminating in the genocide?

Much of the literature on the Rwandan genocide blames radio broadcasts for influencing the decisions of formerly convivial neighbours to participate in the killings. Few writers are explicit in their condemnation of radio as the cause of the genocide, but many lay the blame, rather simplistically, by implication. And they all cite the broadcasts on Radio-Télévision Libre des Mille Collines (RTLM), with occasional references to Radio Rwanda, for inciting, fomenting and practically causing the genocide. "Almost everything written on the role of RTLM says essentially the following: RTLM broadcast hate propaganda; there was a genocide; therefore one caused the other" (Carver, 1996, May 23).

Kellow and Steeves (1998) are among the most oft-cited writers who explicitly accuse radio broadcasts of causing the genocide. They claim that "many survivors believe that the extent of the killing and later exodus would not have happened without RTLM. It became the government voice demanding genocide" (Kellow and Steeves, 1998, p. 117). While claiming that "the media worked to instill a pronounced ethnic fear and hatred that previously bad not been part of everyday culture," Kellow and Steeves also suggest that:

The strong establishment of a media dependency for political information, alongside media's agenda-setting and framing roles, and an absence of alternative voices, can set the stage for unusually powerful propaganda campaigns. Such campaigns, in turn, may spark extreme fear and mass panic with catastrophic outcomes, even genocide (Kellow and Steeves, 1998, p. 125).

According to Allan Thompson, the media were not only "instrumental," but was also responsible for "fostering and fomenting the genocide" (Thompson, 2007, pp. 3-4). Frère claims that "a radio station prepared, encouraged and supported the genocide" (Frère, 2009, p. 79). The suggestion 
from both Thompson and Frère appears to be that the plan for genocide was conceived, developed and eventually brought to fruition by Rwandan (hate) media. When Allison Des Forges, considered to be one of the foremost authorities on the Rwandan genocide, claims that the Belgian peacekeepers who died at the start of the genocide were killed "under the stimulus of RTLM broadcasts" (Des Forges, 2007, p. 48), the implication is that their torture and murder might not have happened without the broadcasts.

For his part, Li claims that "regardless of whether all of the news it passed on was true (and many Rwandans recognized that at times it was not), those who killed still built their schedules in part around RTLM and used its broadcast to help guide the details and schedules of work" (Li, 2007, p. 101, emphasis added). And there is also Chrétien's claim that “two tools” were used in the genocide - "the radio and the machete - the first to give and receive orders, the second to carry them out" (quoted in Li, 2007, p. 92). The impression one gets from both $\mathrm{Li}$ and Chrétien is that people did not kill when they were not listening to radio and that those who did kill were acting on orders they had received from the radio. This, as will be shown shortly, was not entirely the case. But as respected popular and academic writers, Chrétien, Des Forges and Li's depiction of radio as one of the key instruments of genocide has helped fuel what Scott Straus describes as the "conventional wisdom" on radio's role in the tragedy (Straus, 2008, p. 611).

The "conventional wisdom" gained even more credence after the UN-mandated International Criminal Tribunal for Rwanda issued a verdict accepting that media, especially radio, had played a central role in the attempt by extremist Hutu elements to get rid of all of Rwanda's Tutsi. In arriving at this conclusion, the court could only point to the fact that in "some cases," people whose names had been broadcast on RTLM had actually been killed and that "a specific 
connection had been established" between the broadcasts and the killings (Pillay et al, 2003, p.

292; emphasis added). The court's international panel of judges also came to the conclusion that:

The nature of radio transmission made RTLM particularly dangerous and harmful, as did the breadth of its reach. Unlike print media, radio is immediately present and active. The power of the human voice, heard by the Chamber when the broadcast tapes were played in Kinyarwanda, adds a quality and dimension beyond language to the message conveyed. Radio heightened the sense of fear, the sense of danger and the sense of urgency giving rise to the need for action by listeners. The denigration of Tutsi ethnicity was augmented by the visceral scorn coming out of the airwaves - the ridiculing laugh and the nasty sneer. These elements greatly amplified the impact of RTLM broadcasts (Pillay et al, 2003, p. 300).

Further, the tribunal essentially made it clear that there was no need for any proof that "the impact of the RTLM broadcasts" caused the genocide. "Incitement is a crime, regardless of whether it has the effect it intends to have," the tribunal said. "In determining whether the communications represent a risk of causing genocide and thereby constitute incitement, the Chamber considers it significant that in fact genocide occurred" (Pillay et al, 2003, p. 300).

Without venturing too deeply into a legal analysis of the ICTR verdict, it needs to be pointed out that the judgment has been variously criticized for, among other things, attempting to reformulate the international jurisprudence on the criminality of hate speech and its role in atrocities such as a genocide.

Greggory Gordon, who was part of the prosecution team in the media trial, is one of those who see little wrong with the ICTR verdict, describing it as providing "an analytic criteria to understand how certain words, their purpose, context, speaker, and target can be examined to determine when the exercise of free speech corrodes into illegal advocacy" (Gordon, 2004, p. 196). He, however, acknowledges that the "judgment may be criticized for a failure to address certain elements in the case." He points out that the tribunal's "trailblazing in the area of incitement has already subjected it to the scorn of some free speech advocates" (Gordon, 2004, p. 
188) and suggests that "the tribunal could have gone into greater detail [about] how subtle forms of speech (e.g. code words, glorification of violence, congratulations) can constitute genocidal incitement" (Gordon, 2004, p. 197).

It is this lack of detail and the court's apparent attempt to rewrite international law that provides much fodder for the tribunal's critics. Jean-Marie Biju-Duval, the French lawyer who defended Ferdinand Nahimana at the ICTR, is one of those who believes the verdict fell short of international legal standards, describing it as "an isolated aberration for which there is scarcely any explanation other than considerations of judicial convenience" (Biju Duval, 2007, p. 347). He adds that:

The ICTR judges, assuming the prosecution's role, attempted to establish a connection, a supposed direct causal link, however tenuous, between the very small number of broadcasts and murders of Tutsi civilians committed after 6 April, thus mistakenly thinking that they could provide posterior proof of criminal incitement. And, to this end, they discarded the rules of criminal procedure and gave probatory weight to allegations and documents that were devoid of any value as legal evidence. Instead of sticking to the indisputable evidence of fact and law, the judges, under the cover of excellent intentions to protect human rights and under pressure from public opinion, took the risk of letting their decision rest on infinitely shifting, crumbling foundations (Biju-Duval, 2007, p. 351).

For his part, the legal scholar Alexander Zahar, who worked with the International Criminal Tribunal for the Former Yugoslavia, simply describes the ICTR verdict as "a very poor precedent:"

Certain human rights activists, journalists and academics have been so successful in forging a common wisdom that radio was the daily purveyor of genocide in Rwanda in April-July 1994 that many who dutifully waded through the Media judgment's copious regurgitation of the evidence in search of the chilling exhortations to fill the graves with innocent Tutsi must have been puzzled by the court's inability to come up with a single example - broadcast on RTLM or printed in Kangura - of a blatant call on Hutu to hunt down and destroy the Tutsi ethnic group (Zahar, 2005, pp. 34 \& 38). 
One of the difficulties the tribunal faced, Zahar reckons, was language. Obtaining accurate translations of what was mostly said and written in Kinyarwanda and capturing the cultural nuances involved, became a linguistic jungle too dense for the tribunal to navigate. One could say that many of those who claim radio played a central role in the genocide might have suffered from the same problem. According to Zahar:

The interpretative error could have been avoided had the tribunal remained alert to its unusually difficult task: to pass judgment in English, on alleged incitement in Kinyarwanda, before defendants who were following proceedings in French translation, using text which were (plainly) second-rate English translations of French translations of the original Kinyarwanda recordings. An acknowledgment of this extraordinary situation and its attendant dangers is nowhere to be found in the media judgment. This is inexcusable in a case decided on shades of meaning, in which, moreover, the prosecutor was not able to arrange for a single witness to testify that he or she was incited by appeals or hints [on radio or in print] to commit genocide (Zahar, 2005, p. 41).

Taken together, the point being made by both Biju-Duval and Zahar is that officials of RTLM and Kangura were convicted on very flimsy evidence, rendering the ICTR verdict a very weak foundation for any claim that the media incited genocide in Rwanda. As Zahar points out:

What the media judgment fatally fails is in convincing us that any one of the passages it cites - tasteless, vile, and occasionally criminal though they may be unambiguously incites genocide. The tribunal often drifts into condemnation of the media for failing to take a robust stance against genocide. But that is not what this case was meant to be about. It was not a question of complicity, but of direct and public incitement. The most disturbing texts, which number less than half a dozen are from late in the war. The absence of an outright call to commit genocide against the Tutsi in the critical month of April 1994 is a point on which scholars of the period, who have staked so much on the postulate of Kangura and RTLM as driving forces of the genocide ought to reflect further (Zahar, 2005, p. 48).

Such emphatic criticism of the ICTR verdict raises the question of how exactly the media influenced the killings in Rwanda in 1994. The simple answer is that there is no concrete proof that majority of the killings were carried out under the directions, instruction and supervision of 
radio announcers. This means that, hypothetically speaking, if radio was taken completely out of the picture, the genocide would have continued apace, with probably only a few lives spared.

Nonetheless, the Rwandan government largely defends its current media restrictions by pointing to the largely unproven claim that there wouldn't have been a genocide without extremist Hutu propaganda. According to the NGO, Reporters with Borders:

The legacy of the genocide has meant that even slight criticism of the government is attacked by the regime as "revisionism" and quickly cracked down on. The authorities use laws against "genocide ideology" and "sectarianism" to punish freedom of expression, which leads to self-censorship (Reporters without Borders, 2011, September 12).

From this, one takes the position that any attempt to convince the government in Kigali to overhaul the current media legislation and align these regulations with democratic principles should necessarily begin with a rebuttal of the conventional wisdom on the media's alleged central role in the genocide. Such a rebuttal would be grounded in Rwanda's history, communication theory and the confessions of the most active participants in the genocide - people such as JeanBaptiste Murangira who have the blood of their compatriots on their hands.

As the preceding chapters in this study suggest, Rwanda's history - from the "Hamitic hypothesis" to the social revolution of 1959 and the RPF invasion of 1990 - made the genocide almost completely unavoidable. A nation founded on a racist ideology that sanctions exclusion and discrimination as public policy would soon collapse in bloody ruin.

For Rwanda, the cracks started emerging in the campaign for independence. The manner in which the colonialists handed power over to the Hutu majority in an "ethnic transfer of power" (Prunier, 1995, p. 49) made ethnic rivalry inevitable. The rampant massacres of Tutsi following the end of colonialism, with Tutsi exiles attempting to restore the deposed monarchy, further widened the schism between the two groups. The fact that most of these massacres in this period were 
supervised by government officials and largely went unpunished almost normalized and institutionalized atrocities against the Tutsi population (see Mamdani, 2001, p. 129; Gourevitch, 1998, pp. 64-65). This did not just lay the foundation, but also established several precedents, or "practise genocides" (Kinzer, 2008, p. 99), culminating in the tragedy of 1994. "It was not the revolution, but the attempted restoration and the repression that followed, that opened the gateway to a blood-soaked political future for Rwanda” (Mamdani, 2001, p. 130).

Kellow and Steeves ignore this important historical fact when they claim that "the media worked to instill a pronounced ethnic fear and hatred that had not previously been part of everyday culture" (1998, p. 125). As Zahar points out, long before 1994 Rwanda was "a loudly racist society" (Zahar, 2005, p. 45). It is the racism that sowed the seeds of the genocide. Accusing the media of instilling a "pronounced ethnic fear and hatred" in Rwandan society amounts to a significant disregard for historical reality.

In the first decade of independence, those who organized themselves into killing brigades to slaughter their Tutsi neighbours did so without any encouragement (not to mention incitement) from radio or any other media. They did so because authority figures they looked up to told them it was their patriotic duty to hound and kill Tutsi. In 1994, the same authority figures who had presided over the massacres in the years following independence, were to be found co-ordinating and directing the massacres.

Names such as Théoneste Bagosora come to mind. He and other extremists of his generation had been deeply involved in the "Social Revolution" of 1959 and the massacres which followed it. They used the context and pretext of a civil war being waged against a largely Tutsirebel army, alongside a so-called multi-party democratic contest as the perfect opportunity to finish off what they had started more than three decades earlier. "We can see that the actual 
organizers of the genocide were a small tight group, belonging to the regime's political, military and economic elite who had decided through a mixture of ideological and material motivation radically to resist the political change which they perceived as threatening," according to Prunier. "Many of them had collaborated with the killer squad in earlier massacres, and shared a common ideology of radical Hutu domination over Rwanda (Prunier, 1995, p. 242).

Long before this extremist group thought of importing radio transmission equipment to start RTLM it had taken delivery of shiploads of machetes from China (see Melvern, 2006), which they indiscriminately distributed to the unemployed Hutu hordes which made up the Interahamwe and Impuramugambi militias, estimated to be as large as about 50,000 - "approximately the strength of the regular armed forces” (Prunier, 1995, p. 243). The training these militia members received to "kill, with emphasis on killing at speed" (Melvern, 2006, p. 26) took little account of radio. Lists were prepared with names and addresses of people to be killed and handed over to these militias (see Prunier, 1995, p. 224) and much of the instructions they received were not publicly broadcast on radio - contrary to Chrétien's claims.

Of course there were instances where radio announcers told these militia members at roadblocks what to do, who not to let through or where Tutsi were to be found. But to suggest, as Chrétien et al do, that the radio issued commands to kill, while the machetes were used to carry out the killings is a gross exaggeration that needlessly demonizes radio as a medium and journalism as a profession. And as the media rights NGO, Article 19 points out, it might even appear that a lot of the popular notions about radio's role in the genocide are not based on fact or evidence:

Despite allegations by the international media, RTLM does not appear to have explicitly called for the people to exterminate Tutsi civilians. The phrase, "the grave is only half full, who is going to help us to fill it?" is frequently [attributed] to 
RTLM by the international media, but Article 19 found no evidence in either transcript or in witness testimony to support its usage (Article 19, 1996, p. 67).

No one can deny that radio promoted hate in Rwanda before the genocide, but to suggest that the genocide would not have taken place without radio amounts to a denial of the weak historical foundations on which modern Rwanda was built. This is a history replete with an almost visceral hatred that was transmitted from generation to generation without the use of radio, hatred that resulted in several pre-genocide massacres that occurred without any instructions from a radio announcer.

The intent of the organizers of the genocide was not to use radio as a tool for implementing the genocide, as Chrétien and others suggest. They knew radio could be useful in preparing minds for what was to come, which had been meticulously planned. But they were also aware radio wasn't what they ultimately needed to push neighbor to kill neighbor. The one thing that could guarantee mass participation in the killings was intimidation.

For evidence that radio (or for that matter, the media generally) was not as influential in the genocide as many have claimed, one needs to first examine the testimonies and confessions of those convicted of engaging in the killings. Before that, however, it is important to draw some attention to the nature and character of those who perpetrated the bloodshed.

The genocide started in Kigali with massacres spearheaded by members of the presidential guard as well as the Interahamwe and Impuramugambi militants. As it progressed, district administrators joined in, killing in a perverse show of leadership by example and recruiting ordinary folk to do the same, often under threat from the armed militia gangs. "The efficiency of the massacres bore witness to the quality of the Rwandese local administration and also to its responsibility," according to Prunier. "If the local government had not carried out orders from the 
capital so blindly, many lives would have been saved... The vast majority of civil servants carried out their murderous duties with attitudes varying from careerist eagerness to sullen obedience" (Prunier, 1995, pp. 244 \& 246).

The ordinary folk, who joined the killing spree (under threat from the militia gangs) included poor farmers, unemployed youth, Rwandan Hutu displaced by the civil war and Hutu refugees fleeing the unrest in Burundi. It must be borne in mind that by the time the genocide started Burundi had lost two heads of state within a few months of each other. The first, Melchoir Ndadaye, a Hutu, was killed in a coup by Tutsi army officers and the second Cyprien Ntaryamira, another Hutu who had been in office for just two months, died in the same plane crash as Habyarimana. The Burundian Hutu refugees, therefore, felt they needed to fight on the side of their Rwandan kin. "Not only did Burundi refugees take an active part in the political violence of 1994," according to Mamdani. "Those who did were responsible for some of the most gruesome tortures that marked the genocide" (Mamdani, 2001, p. 205). That, notwithstanding most of the genocidal killers were Rwandan Hutu - “ordinary peasants” forced to kill other ordinary peasants (Prunier, 1995, p. 247).

Several researchers have interviewed many of these convicted killers, often within the confines of penitentiary walls. Hatzfeld conducted one of the most comprehensive of these interviews at the prison in Rilima, south of Kigali. His interviewees, including Jean-Baptiste Murangira and his gang, speak on a wide range of subjects including their thoughts on their Tutsi neighbours and how they got involved in the killings. Even though they admit to having been exposed to hate propaganda on radio, none says anything about killing in response or in obedience to what they had heard on radio - casting doubts on the claims by both Chrétien and 
Li. Rather their accounts portray a situation where intimidation by both militia and local government authorities forced them to join the killing spree.

Fulgence Bunani, for example, says he joined the killing after the municipal judge in his area summoned all the Hutu to a meeting attended by a large contingent of the Interahamwe militia. "The judge told everyone there that from then on we were to do nothing but kill Tutsi," he says. "Well, we understood: that was the final plan." Bunani adds that those who came to the meeting unarmed were seriously reprimanded:

That day misinformed guys had come to the meeting without bringing a machete or some other cutting tool. The Interahamwe lectured them: they said it would pass this once but had better not happen twice. They told them to arm themselves with branches and stones, to form barriers at the rear to cut off any escaping fugitives (quoted in Hatzfeld, 2005, p. 11).

Jean-Baptiste Murangira, speaks about how after the plane crash that killed the president, he and his friends gathered in bars, "listening to the radio, watching Tutsi flee, chatting and joking without planning a thing." Then the mayor showed up and everything changed:

On April 10 the burgomaster [local government chief] in a pressed suit and all the authorities gathered us together. They lectured us, they threatened in advance anyone who bungled the job, and the killings began without much planning. The only regulation was to keep going till the end, maintain a satisfactory pace, spare no one and loot what we found. It was impossible to screw up (quoted in Hatzfeld, 2005, p. 15).

None of the killers Hatzfeld interviewed mentioned listening to the radio for instructions or using the radio to "help guide the details and schedules of work," as Li claims (2007, p. 101). They rather say that they were ordered, face-to-face, by local government officials to go and kill. They knew the risks they faced if they didn't do as the authorities had instructed. "Rule number one was to kill," Pancrace Hakizamungili says. "There was no rule number two. It was an organization without complications" (quoted in Hatzfeld, 2005, p. 10). 
In fact, in this group Hakizamungili is the only one who alludes to being "prepared the right way by the radios and the official advice" and how these made him "obey more easily, even if the order [was] to kill." But then, he also points out that the gang members "feared the authorities' anger more than the blood [they] spilled" (quoted in Hatzfeld, 2005, p. 71). Pio Mutungirehe, another member of the gang, sums up the extent of the intimidation that got them involved in the genocide:

Anyone who had the idea of not killing for a day, could get out of it. No problem. But anyone with the idea of not killing at all, could not let on, or he himself would be killed while others watched. Voicing disagreement out loud was fatal on the spot. So we don't know if people had that idea. Of course, you could pretend, dawdle, make excuses, pay [a fine for not participating for the day] - but above all you could not object in words. It would be fatal if you refused outright, or even hush-hush with your neighbour. Your position and your fortune could not save you from death if you showed kindness to a Tutsi before unfamiliar eyes. For us, kind words for Tutsi were more fatal than evil deeds (quoted in Hatzfeld, 2005, p. 76).

A similar point is made by an unnamed Lutheran minister, explaining why he carried a club around to give the impression that he was participating in the genocide. "Everyone had to participate," he told a reporter. "To prove that you were not [with the rebels] you had to walk around with a club. Being a priest was not an excuse” (quoted in Mamdani, 2003, p. 226).

This atmosphere of danger for those who refused to participate in the genocide had been created by the government's portrayal of even its mildest political opponents as accomplices of the rebel invaders. To appreciate this point even more, one has to bear in mind that the genocide started with the killing of Hutu opponents of the regime, beginning with the prime minister, Agathe Uwilingiyimana, and the information minister, Faustin Rucogoza.

For the Hutu peasants on Rwanda's hills, therefore, even those who were not exposed to hate propaganda, there was more than ample evidence that they risked much, especially their lives, 
if they did not participate in the genocide - either as "killers, lookouts, informants, looters, logisticians [or] cheerleaders” (Li, 2007, p. 91). This risk was never conveyed to them on radio. They saw it right in their communities. It was the attempt to avoid the risks of non-participation that got many involved in the killings, and Chrétien, rightfully, characterize a large number of the genocidal killers as "innocent murderers" (quoted in Prunier, 1995, p. 247).

Without the intimidation of local government officials and the thugs from the Interahamwe and Impuramugambi militia, the extremists would not have secured the participation of so many Rwandans in the killing sprees that constituted the genocide. Those militia were more central to the execution of the genocidal plan than radio could ever have been. To further drive home the point, consider, for example, the case of the Tutsi mayor of Butare, Jean-Baptiste Habyarimana (no relation of the assassinated president). For several days, as people were being killed in other parts of the country, all was calm in his municipality. Unlike other burgomasters, he had simply refused to follow the instructions from the government in Kigali to lead the killings in his district. The central government in Kigali was so infuriated by the situation that none other than the interim president went to Butare with contingents from both the presidential guard and the militia “to rebuke the population for sleeping," according to Mamdani (2001, p. 218). A new mayor, more enthusiastic about keeping the population "awake" and "working" (that is, killing Tutsi), was then installed:

As the town population gathered to witness the investiture of the new prefect, the former prefect and his family were murdered by the presidential guard. For those harboring moral ambivalence about the new direction of the "war," the signal was clear: any wavering in the face of orders from above would mean certain death. Fear could silence opposition, but it could not generate enthusiasm. To sustain the killing in Butare, the new officials had to bring in armed groups from the outside and unemployed youth from the hills (Mamdani, 2001, p. 219). 
According to the media rights NGO, Article 19, "massacres began in Butare on the day of [mayor Habyarimana's] dismissal and included some of the worst in the entire period of the genocide" (Article 19, 1996, p. 77). The point here is that if the people of Butare, who also heard the hate radio broadcasts, did not go about killing their neighbours because they had a leadership that was not intimidating them to engage in mass murder, one could come to the conclusion that the radio broadcasts had little influence, if any, on their decisions to participate in the killings. What got them involved in the killings, rather, was the intervention of the interim president and his entourage, who pushed their mayor out of the way and showed them the consequences of refusing to kill their neighbours. The same scenario was replicated around the country with lower ranking government officials. Thus Scott Straus, another researcher who has interviewed killers in the genocide, emphasizes that:

There is evidence that radio broadcasts had a conditional effect of catalyzing some hardline individuals, but most respondents claim radio was not the primary reason that they joined attacks. Most commonly, individuals say they chose to participate in the genocide after face-to-face solicitation, usually from an authority, elite figure, or a group of violent men. The general pattern of mobilization at the local level reported by respondents is that elites and young toughs formed a core of violence. They then traversed their communities, recruiting a large number of Hutu men to participate in manhunts of Tutsi or to participate in other forms of "self-defense," such as manning roadblocks. The recruiting, most often, was done house to house, at markets or rural commercial centres, at rural bars or at meetings called by local authorities. Radio in short was not the principal reason why men entered into violence, rather mobilization was locally organized and face-to-face (Straus, 2008, p. 626).

It is at this point that the communication theories of media effects can also be employed to further argue the point that radio's influence on the genocide was only peripheral - not as central as the "conventional wisdom" holds. As McQuail puts it:

The media are rarely likely to be the only necessary or sufficient cause of an effect, and their relative contribution is extremely hard to assess. There are many good theoretical reasons for this uncertainty, and even common sense and practical 
knowledge waver when faced with questions of media effects in the contested areas of morals, opinion and deviant behaviour. On many such matters there can be no question of the media being a primary or sufficient cause, and it is impossible to take full account of all the possible psychological, social and cultural factors involved (McQuail, 2005, p. 457).

McQuail's summary of the current state of research into media effects is that:

It was not that the media had been found to be without effects or influence; rather there was no direct or one-to-one link to be expected between media stimulus and audience response. Media were shown to operate within a pre-existing structure of social relationships and a particular social and cultural context. These factors took primacy in shaping the opinions, attitudes and behavior under study and also in shaping media choice, attention and response on the part of audiences. It was also clear that information acquisition could occur without attitude change and attitude change without changes in behaviour (McQuail, 2005, p. 459).

Nonetheless, much of the available research on media effects cast much doubt over the conventional wisdom on the role of the media in the genocide. Dallaire, one of those who makes a case for radio's supposed central role in the genocide, claims that "in Rwanda, radio was akin to the voice of God" and that "if radio called for violence, many Rwandans would respond, believing they were being sanctioned to commit these actions” (Dallaire, 2003, p. 272).

Besides being condescending, statements like these could be deemed as insulting to the intelligence and the courage of the numerous Rwandans, especially those in places such as Butare who practically ignored radio messages, as well as the many others who braved the intimidation from all sides to help their Tutsi neighbours. Views such as the one expressed by Dallaire essentially mean that Rwandans could not think for themselves and could not weigh the justification or morality of any action radio suggested they take. They just did as they were told by faceless radio announcers. Such views belong to an old, much-discredited communication theory known as the "silver bullet" or "hypodermic needle" model. This theory holds that media is quite effective in "injecting a message directly into the bloodstream of a passive and gullible public," 
according to Croteau and Hoynes (2014, pp. 235 \& 236). "Focussing on mass effects, [proponents] viewed human responses to the media as uniform and immediate," Jowett and O’Donnell point out. "The magic bullet theory was not based on empirical generalizations from research, but rather on assumptions of the time about human nature" (Jowett and O'Donnell, 1999, p. 164). Its weak foundations, with no empirical research to prove its main thesis, was the very reason why the magic bullet theory failed to sway many communication scholars. In a sense, it viewed human beings as an "unthinking herd," (quoted in Jowet and O’Donnell, 1999, p. 164) who were "uniformly controlled by their biologically based 'instincts' and reacted more or less uniformly to whatever stimuli came along” (Lowery and Fleur, 1995, p. 400). More rigorous research over the years discredited the magic bullet theory, while suggesting "relative media impotence" or, at best, "limited effects" (McQuail, 2005, p.459). Researchers also explored the effects of political campaign messages and came up with a two-step flow theory, which was based on the finding that:

Political campaigns seem to have relatively little impact on people, and that their basic effect seems to be that of reinforcing beliefs people already hold... People are strongly affected by group affiliations, by personal contact, and by information from opinion leaders. These individuals tend to be better informed than the ordinary person, tend to be from elite segments of society, and generally have a relatively high status (Berger, 1995, p. 67).

The two-step flow theory is, therefore, explained thus:

In the first step, the media influence opinion leaders; in the second step, these opinion leaders influence others with whom they have direct contact in groups of one sort or another (Berger, 1995, pp. 67-68).

The situation in Rwanda in 1994 was more complicated than the simple transmission of political campaign messages. But the explanation offered by Berger even in the context of the dissemination of messages of hatred leads full cycle to the point made earlier about local 
government officials being more influential than radio in people's decisions to join in the killings. In the case of Rwanda, however, instead of peaceful persuasion, the opinion leaders used violent intimidation to get people to act on whatever they (the opinion leaders) may have heard on the radio, which in any case only reinforced their (opinion leaders') own beliefs about the Tutsi being alien invaders of Rwanda.

The point can also be made that in the particular case of Rwanda, local government officials were implementing a state-sanctioned policy - kill all the Tutsi - which did not need elaboration on radio. With intimidation as the main tool of persuasion, those who actually forced the peasants to kill may have done so without necessarily obtaining instructions from radio. In other words, even though the radio preached hatred, the situation in Rwanda was such that it was quite easy for the first part of the two-step process to be skipped. The opinion leaders got much of their information and instructions about what needed to be done (kill Tutsi) from the extremist government in Kigali through other communication channels - not from radio. They then kept passing the message down to the lower rungs of society, using face-to-face contact and all manner of intimidation until the country's poorest Hutu peasants felt so threatened that the only way for them to save their own lives was to take the lives of others.

The final argument to be made against the claim of radio's supposed central role in the genocide is based on the broadcast reach of the main network for extremist Hutu propaganda, RTLM, and the number of Rwandans who were actually exposed to its messages of hatred. After exploring this issue in some detail, Straus came to the conclusion that "available evidence suggests a significant exposure gap between broadcast range and where the genocide occurred" (Straus, 2008, p. 617). What this means, essentially is that killings took place in areas outside of the capital, Kigali, where RTLM transmission signals were either too poor or almost impossible to receive. 
Further, Straus, grouping the RTLM broadcast into those from the "high genocide period" (when the killings were most intense) and the "low genocide period" (when the killings were tapering off) found that:

During the high genocide period, there are some hateful and inciting messages, but they are not overwhelmingly frequent. But during the low genocide period, the inflammatory broadcasts are frequent and virulent... In sum, the qualitative analysis of the existing high genocide RTLM broadcasts paints a more complex picture than the conventional wisdom suggests. The tone on RTLM was belligerent; the ideology was consistently pro-government, nationalist, virulently anti-rebel, and hostile to Tutsi in general. But the available full transcripts from the high genocide period complicate the "Radio Machete" image of a station openly and repeatedly calling for genocide (Straus, 2008, pp. 623-624; p. 625).

The implication of these findings is that, put bluntly, the more RTLM urged people to go out and kill, the less blood was actually shed. One explanation for this could be that in the "low genocide period," there were fewer remaining Tutsi in the country and they had become more difficult to find, capture and kill. Another possible explanation could be that seeing their plan of extermination falling apart, the authority figures had started to pack up in preparation for the ensuing exodus into exile and the killers themselves had grown weary. Either way, there are two clear scenarios. First, more people were killed when there were fewer calls on radio for Rwanda to rid itself of the Tutsi. Secondly, there were fewer killings when there were more frequent calls on radio for the alleged Tutsi menace to be halted. Radio, therefore, could not have had the impact the conventional wisdom suggests.

Charles Mironko, exploring the question of exposure to the RTLM broadcasts, also interviewed some convicted killers and came to the conclusion that:

While some Rwandan villagers may have listened to broadcasts, many stated that they did not. They heard the message from others, however, and understood the ideological significance of certain songs, speeches and the reporting of current events from others. Nevertheless, this information alone did not cause them to 
kill. It is, therefore, necessary to explore other reasons why these Rwandans took part in the genocide (Mironko, 2007, p. 134).

For his part, Richard Carver takes the position that the very fact that communication scholars and social psychologists have long argued but never came to any consensus on the matter of media effects is in itself a repudiation of the notion that radio caused the genocide in Rwanda. "Even in situations where the media has played an extremely pernicious role [as in Rwanda], they have been singled out for disproportionate blame by people who should know better," he says:

If we were talking about almost any other issue - violence on television, pornography or whatever - those arguing [that radio caused the genocide] would attempt to demonstrate at least a cursory link between the broadcast and the action. There is abundant research to suggest that it is impossible to draw a linear causal link between what people see or hear in the media and how they behave. But because it is genocide, we abandon our critical faculties (Carver, 1996, May 23).

While conceding RTLM's role in organizing and directing some of the murders by alerting militias to where there were people to be killed, Carver rejects the conventional wisdom. "The radio may have produced propaganda for the genocide, but did not incite it," he says (2000, p. 191), emphasizing that:

Re-examination of the Rwandan genocide has been a frenzied retrospective search for the moments when the course of history might have been diverted. Yet the probability is that in late 1993 and early 1994 nothing short of concerted international action could have prevented the genocide. The massacres would have taken place with or without the RTLM broadcasts (Carver, 2000, p. 192; emphasis added).

The media rights NGO, Article 19, after cataloguing almost all of RTLM's iniquities came to a similar conclusion. "Genocide is not caused by the mass media," the group points out. "At worst, they may abet the process, but inflammatory media coverage is essentially a symptom of a process resulting from other causes:” 
The conclusion to be drawn from this is precisely that the international community needed urgently to address the rise in violence by the MRND and CDR militias and the plans for genocide. This was not primarily a media issue. The genocide would have gone abead with or without RTLM (Article 19, 1996, pp. 105, 108; emphasis added).

Alan Kuperman, who has written extensively on various ethnic conflicts, also points out that:

Radio broadcasts were not essential to perpetuating or directing the killings. Moderate Hutu were not usually swayed by radio broadcasts, but rather by intimidation from extremist authorities. Moreover, orchestration of the genocide relied not merely on radio broadcasts but on the government's separate military communications network. Indeed the broadcast range of the radio transmitter of the infamous RTLM was limited to greater Kigali (Kuperman, 2001, p. 91).

In the final analysis, one can say that radio (and for that matter the media) was neither a necessary nor sufficient cause of the genocide. The media didn't "fuel" the genocide as the cover of Allan Thompson's book (2007) suggests. From the formation of militias to their training and the importation of machetes, one could draw the conclusion that there was a plan to exterminate Rwanda's Tutsi. This plan might have counted on the possibility that radio could help spark a spontaneous urge among Hutu to kills Tutsi. But as Prunier points out:

The death-lists had been carefully distributed to the future killers, who acted in coordinated and systematic ways in order to catch their intended victims. There was little spontaneity in the whole process, apart from some young street urchins joining in the bloody fun. Everything went ahead with the precision of a wellrehearsed drill (Prunier, 1995, p. 224).

To suggest that radio fuelled the genocide is to imply that Rwandans acted like automatons, responding spontaneously to broadcasts allegedly urging them to go out and kill their neighbours. There is no evidence of such broadcasts. What is not in doubt, however, is that radio was used to issue instructions to the militia to be vigilant and deal with supposed rebel elements who had allegedly infiltrated the civilian population. Moreover, the fact remains that majority of the killers in Rwanda in 1994 were government-recruited militia men, not ordinary folk who decided to turn 
savagely against their neighbours. What must not be forgotten is that the genocide was a political project - just as the very definitions of Hutu and Tutsi are rooted in politics. "[The genocide] was some Hutu killing Tutsi (and quite a number of Hutu as well) in pursuit of a purely political agenda," according to Carver. "Many of the accusations against RTLM are ill-informed and inaccurate. They are coloured by large brushfuls of hindsight and have led the international community to draw the wrong lessons from the Rwandan tragedy" (Carver, 1996, May 23).

It is not only the international community that has drawn the wrong lessons from the tragedy. The Rwandan government itself has taken advantage of the scapegoating of the media to adopt a regulatory framework, largely based on the erroneous claims that the genocide could not have happened without radio (or the media). Many see these regulations as both repressive and aberrant in a country that professes to be democratic.

In the push for reform, it is imperative that the blame for the genocide is laid where it should be - at the doorsteps of both the central government and the local government authorities in Rwanda at the time. These authorities co-opted the media, using propagandists parading as journalists to spread their message of hate. By serving the interests of their paymasters and not the wider public interest, the announcers of RTLM do not to deserve to be called journalists, as many writers have done. At the height of the genocide, these announcers turned into "combatants" (Biju-Duval, 2007, p. 351), "soldier-broadcasters, who wore military uniforms and carried out the orders of the only authority that had the means of commanding obedience in the midst of the massacres: the army" (Biju-Duval, 2007, p. 355). The true journalists of the day were either killed or chased into exile for refusing to toe the official line. The Media High Council of Rwanda estimates that as many as 53 journalists were killed during the genocide "either because they were Tutsi or as a result of their ideological thoughts against the genocidal regime" (Media High 
Council of Rwanda, 2013, April 18). Even before they were killed these journalists were under constant harassment from a regime using "national security" as a cover to pass legislation against independent, critical journalism:

Government officials issued several warnings to independent journalists telling them not to step out of line and in May 1991, the Council of Ministers announced that elements of private press were threatening national security... Any criticism of government [a report on Radio Rwanda warned] would constitute "disinformation," and negative coverage of the Rwandan troops, including their losses to the RPF, would be classified as "an attack on the morale of the armed forces" - nothing less than treason (Article 19, 1996, pp. 28-29).

Many would argue that the situation in Rwanda today, with regard to the government's approach to independent journalism is not much different from the pre-genocide era. While the regime before the genocide used the raging war as an excuse to beat the media into submission, the regime after the genocide is using the possibility of renewed conflict to cower the media justifying media repression with highly exaggerated claims about the role of the media in the tragedy of 1994.

The truth actually is that there were courageous and professional journalists who did their best to help prevent the genocide. Most ended up dead. These were the "journalists of good conscience" (Thompson, 2007, p. 441) and they offer the best examples that could be used to encourage professionalism in the Rwandan media as a means for promoting national reconciliation. Using the bad examples of a few fringe elements who were co-opted by the genocidal machinery to suppress journalism and free speech in Rwanda is the worst tribute any government could pay to the journalists who lost their lives resisting the genocidal regime. The exaggeration of the media's role in the genocide has unwittingly enlarged what Reyntjens describes as the Rwandan government's "genocide credit." This is a sort of moral high ground adopted by the regime as "an ideological weapon allowing the [government] to acquire and maintain victim 
status and to enjoy impunity for its own [wrongdoings]" (Reyntjens, 2010, p. 27). Using this genocide credit, the regime has succeeded in creating a situation whereby "the spaces of free expression are almost all invaded or reduced to a minimum in order to prevent contestation," according to the League for Human Rights in the Great Lakes Region (quoted in Reyntjens, 2010, p. 13). This means that those who step out of line and dare to raise a voice against the Tutsidominated regime will most probably find themselves endangered in diverse ways by a government which claims to be democratic. Journalists, along with the activists and politicians they interview and write about, are often the ones most at risk. 


\section{Chapter 5}

\section{SHAMED AND TAMED}

When the genocide ended in July 1994, Rwanda was in utter ruin. The nation existed in all but name. All its institutions (including the media) had collapsed and there wasn't even a cent in the national kitty. As Nyamwasa et al point out, the most immediate and pressing tasks facing the new government were:

Restoring law and order, organizing the provision of humanitarian assistance to the population; re-establishing and strengthening institutions of government to drive the reconstruction of the country; encouraging and facilitating peaceful repatriation, resettlement and re-integration of refugees; laying a foundation for sound economic recovery and development; establishing democracy and the rule of law and identifying and implementing strategies to promote national unity and reconciliation as foundations for sustainable peace and stability (Nyamwasa et al, 2010).

Media development, much less the ideal of free expression, was clearly nowhere near the new government's priorities. And with hate media having been so pervasive during the genocide, the new regime was very suspicious of journalists and anyone who had been involved in one way or another with the media in the period leading up to the genocide. Moreover, as Pottier points out the post-genocide government had come into power with its own "doctrine of information control" (Pottier, 2002, p. 55) which it intended to use for "rewriting" the history of both Rwanda and the entire Great Lakes region of Africa. This doctrine would also be used to spread "an RPFfriendly but empirically questionable narrative" (Pottier, 2002, p. 53).

This meant that the new regime, predominantly Tutsi with a few Hutu in its ranks, was in no mood to countenance any uncomfortable questions, not to mention uninvited, unwanted scrutiny from anyone. Such questioning and scrutiny often comes from journalists, politicians and civil society actors. And it was the people in these groups that the government needed to work 
with (or against) if its doctrine of information control was to succeed. That explains why immediately after the genocide, "official news was managed with a strategic and defensive objective" (Frère, 2007, p. 96).

In terms of media development, therefore, the regime's first focus was on rebuilding outlets that would be under the direct control and supervision of the government. As Radio Rwanda went back on air with staff from Radio Muhabura (the former rebel propaganda station), some newspapers "timidly" started appearing on the newsstands (Frère, 2007, p. 95). In the refugee camps in neighbouring Zaire, Hassan Ngeze, the former editor of Kangura, and some other extremist propagandists of the deposed regime started a newspaper, which focused on publishing articles dismissing the fact that a genocide had occurred in Rwanda. All this happened as former Interabamwe militia were regrouping in the refugee camps and launching sporadic attacks on Rwanda. The post-genocide regime was, to say the least, greatly alarmed by these developments:

Faced with the threat represented by this strike force reorganizing just a few kilometres from its borders, the new Rwandan authorities were suspicious and anxious to control the circulation of news... Arrest followed arrest, including within the public media, and some professionals were accused of having taken part in the genocide. Confusion reigned at the headquarters of some international associations for the defense of journalists and freedom of speech, which treated some of those who had been arrested on suspicion of participation in the genocide as prisoners of opinion (Frère, 2007, p. 96).

At least two of the journalists arrested in this period were, indeed, prisoners of conscience. There is, for example, the case of Dominique Makeli and Tatiana Mukakibibi, who had both been working with Radio Rwanda in the years before the genocide. Makeli was accused of "incitement to genocide." The accusation stemmed from a report he filed in May 1994 on a supposed appearance of the Virgin Mary in the township of Kibeho. In this Catholic nation, such 
apparitions were widely publicized and were followed with a great deal of religious zeal. The prosecutor claimed that Makeli's report had quoted the Virgin Mary as saying "the parent is in heaven" and that in the context at the time it meant that the former president, Habyarimana, whose assassination provided the spark for the genocide, was in heaven. According to the prosecutor, the population had interpreted Makeli's report to mean God supported the former president and, by extension, the extermination of the Tutsi (see Reporters Without Borders, 2003).

In the case of Mukakibibi, she was picked up in 1996 for murder and alleged weapons distribution. Mukakibibi insisted that "she was framed by people in her village because [a Catholic priest she worked with after the genocide] sent reports to international organizations, denouncing violent acts by Tutsi in retaliation for the April 1994 massacres" (Reporters Without Borders, 2003).

Accusations of participation in the genocide or attempting to start another one would be used very frequently in the coming years to silence critical journalists and civic society voices as the regime stepped up the implementation of its doctrine of information control.

On the political front, the regime started losing the "illusion of inclusiveness" with the resignation of some of its most high-profile Hutu elements. "Hutu elites became the victims of harassment, imprisonment and physical elimination," according to Reyntjens. "Provincial governors, local mayors, head teachers, clerics and judges were killed in increasing numbers" (Reyntjens, 2004, p. 180).

The pattern that can be discerned here is that anyone, especially Hutu, who challenged the regime's new narrative risked a confrontation with the government, a confrontation which ended in death for some. Fed up with the situation, Faustin Twagiramungu, the first post-genocide prime 
minister (a Hutu who had been in office for just about a year), stepped down along with Justice Minister Alphonse Nkubito and Interior Minister Seth Sendashonga (who was later killed in Nairobi, see The Economist, 2010, June 24). These high-ranking Hutu went into exile along with other professionals, including journalists and leaders of civil society. "As soon as they were out of the country they made allegations of concentration and abuse of power, outrages by the army and intelligence services, massive violations of human rights, insecurity, discrimination against Hutu and even against Tutsi genocide survivors" (Reyntjens, 2004, p. 180).

Then came Rwanda's decision to wage war in Zaire against the remnants of the previous regime's army and militia. This was essentially a Rwandan civil war waged on foreign soil, with two major invasions of Zaire in 1996 and 1998. "Although security concerns were initially the driving force for the war the economic exploitation of Rwanda's rich and vast but weak neighbour eventually became the main, though never acknowledged, reason” (Reyntjens, 2004, p. 204).

As it plundered Zaire, the government in Kigali pursued a radical program of social engineering in Rwanda, forcibly moving thousands of people from their ancestral lands and resettling them in designated villages. It also banned all references to ethnicity, meaning that it had suddenly become anathema to even mention or refer to one's Hutu or Tutsi identity. In the context of this extra-territorial civil war, the "ambitious, security-driven form of social engineering" (Reynjens, 2004, 196), the agenda of reconstruction and reconciliation and the regime's strong belief in its own doctrine of information control and management, the government gradually and forcefully made it clear in many different ways that it would tolerate neither opposition nor dissent and criticism.

This was when Tutsi survivors and politicians increasingly started to join the Hutu political elite that had fled into exile. Among the most prominent Tutsi to flee was the speaker of 
parliament, Joseph Sebarenzi, a Tutsi genocide survivor. Alarmed that the transitional parliament was turning into a mere rubber stamp, he voiced his concerns and tried to win more independence for the legislature to enhance its oversight of the executive arm. These overtures didn't go down well with the RPF, the former guerrilla army which had become the dominant political force in Rwanda:

By the end of 1999, parliament had investigated many cases of corruption and censured two ministers. The growing power of the legislature ended when the RPF engineered my removal as speaker. I vividly remember my last meeting with [then vice-president] Kagame. As I asked questions, he leaned forward and pointed a finger at me, "If you don't resign, I will get involved." I understood what he meant. I resigned the next day (Saberenzi, 2011, p. 346).

A few days after stepping down, Sebarenzi fled into exile, hidden in the back of a truck. Then followed the decision of the second prime minister of the transitional period to leave the government. But the most high-profile resignation of the period was that of the President of the republic, Pasteur Bizumungu. He claimed his resignation was for "personal reasons" (BBC, 2004, June 7) and declined Uganda's offer of asylum (see Reyntjens, 2004), choosing to stay on in Rwanda. He would come to regret this decision.

Amid the political intrigue of the transitional period, independent-minded journalists were taking as much heat as the politicians who refused to follow the government willy-nilly. The challenge of raising funds to publish their newspapers in neighbouring Uganda (it was too expensive to print in Rwanda) appeared to be the least of their problems. After navigating financial and logistical obstacles to publish in Uganda, newspapers carrying articles the government didn't like were confiscated at the border. The editors of Rwanda Newsline were threatened after publishing articles critical of the Rwandan army's presence in Zaire. They were accused of being in the pay of "negative forces," which is "a term loosely coined by the RPF by 
which it terrorizes all its critics and opponents into exile" (Reyntjens, 2004, p. 181). Around the same time, the entire editorial staff of Imboni fled into exile in Belgium, from where they published a satirical article "apologizing for having publicly expressed our indignation at the spirit of sycophancy, the deliberate process of impoverishment of society and public opinion" (ibid.).

By 2003, three journalists had been either assassinated or had simply "disappeared in apparent retaliation for their work" (Waldorf, 2007, p. 408). They included Manasse Mugabe, a director of the United Nations Kinyarwanda radio service who "disappeared" in August 1995. Appolos Hakizimana was killed in April 1997 and Emmanuel Munyamenzi, a journalist with the re-established Radio Rwanda, was killed in May 1998 after he had been accused of "sabotaging a program" (ibid.).

As the transitional period came to an end, the Rwandan government acquired the habit of accusing its opponents, critics, journalists and all dissenters in general of "genocide ideology," marking a new stage in the regime's use of "accusatory practices" to "stifle political dissent and independent civil society:"

Starting in 2001 the government's accusatory language changed and evolved: prominent Hutu critics have been successively charged with "divisionism," "negationism," and, most recently, "genocide ideology," while Tutsi critics are usually accused of corruption. Genocide ideology has several advantages: it can be applied to any Hutu, not just those implicated in genocide; it is less embarrassing to charge long-serving, integrated Hutu members of government with genocide ideology than with genocide and it evokes a more immediate threat of a return to genocidal killings (Waldorf, 2011, p. 52).

Besides politicians, journalists and human rights activists also bore the brunt of the accusations of "genocide ideology" even before it had been enshrined in law. This compelled the majority of Rwanda's media professionals to either fall behind the government's line or flee into exile. In 2001 Reporters Without Borders started referring to the new president (and former rebel commander), 
Paul Kagame as "a predator of press freedom" as the regime increased its clampdown on independent media (Reporters Without Borders, 2011, September 12; Reyntjens, 2004, p. 196). The independent weekly, Umuseso saw one of its journalists flee into exile and two others imprisoned (see Reyntjens, 2004). The situation led the League for Human Rights in the Great Lakes Region (LDGL) to conclude in 2001 that:

While few journalists are arrested or killed lately, this is not due to a larger openness of the authorities, but rather to the fatigue and/or resignation of a profession that prefers to adopt a low profile instead of seeking confrontation with an authoritarian regime. The degree of press freedom is inversely proportional to the omnipotence of the internal and external intelligence services (quoted in Reyntjens, 2004, p. 197).

It wasn't only Rwandan journalists, however, who were under constant government pressure to conform. A Reuters journalist, Christian Jennings was expelled ostensibly for reporting Kagame's assertion that it was Rwanda's right to divert international aid money to "contribute to the internal war against Hutu extremists" (quoted in Reyntjens, 2004, p. 202). Stephen Smith of the French newspaper, Libération, was also refused a visa and declared a persona non grata. "The chargé d'affaires at the Rwanda embassy in Paris explained that Smith had himself to blame, given the horrors he has written about [Rwanda]," according to Reyntjens (ibid.), who also reports that after the publication of a critical report by Human Rights Watch:

The authorities attacked both the organization and its senior advisor, Alison Des Forges, in the press and at public meetings. The foreign minister published an article accusing Des Forges of being a Hutu supremacist who believed the Tutsi had no place in Rwanda. This accusation was particularly shocking as Des Forges has an outstanding record of [opposing] violence against Tutsi, so much so that she was labelled 'pro-RPF' by the extremists of the former regime (Human Rights Watch, 2004, p. 204).

The Human Rights Watch report just mentioned was issued before the first post-genocide presidential elections. For that election, former president Bizumungu had hoped to launch a bid 
for the presidency by forming a political party known as the Democratic Party for Renewal (PDR). The party suffered a still-birth as it was banned before its official launch. The government accused Bizumungu of attempting to "destabilize the country:"

That argument prompted [a] contentious public debate, which in turn brought restrictions on the press. On December 31 [2001], for example, police arrested Amiel Nkuliza, a reporter for the newspaper Le Partisan who had questioned the circumstances surrounding the December 26 murder of a PDR co-founder. Nkuliza was released [three days later] without charges (Committee to Protect Journalists, 2002).

Journalists who interviewed the former president about his abortive attempt to re-enter the political arena received threats from officials of the intelligence services. The reporters, Thomas Kamilindi and Lucie Umukundwa, stringers for the BBC and VOA respectively, were eventually forced to hand over their recordings to the authorities (see Reporters Without Borders, 2002).

Even before the ban on Bizumungu's party and its fallouts, the regime had been increasingly demonstrating its preference for keeping journalists on as short a leash as possible, all in pursuits of its doctrine of information control. For example, the editor of the Newsline weekly, John Mugabi was detained in 1999 after he refused to name the sources behind a story in which he accused a top official of the defense ministry of taking kickbacks of more than $\$ 3$ million on a contract for the supply of military aircraft (Committee to Protect Journalists, 2000). After being sworn in as president a year later, Paul Kagame “berated local reporters for exaggerating Rwanda’s problems” (Committee to Protect Journalists, 2001). But then he refused to grant presidential assent to a new media bill parliament had passed to impose the death penalty on journalists found guilty of inciting genocide. The bill also prescribed new powers for prosecutors to compel journalists to reveal their sources. "Officials claimed the bill was intended to foster a professional and responsible media:" 
But Rwandan journalists voiced shock and outrage at its content, complaining that the Ministry of Local Government and Social Affairs, which drafted the bill, did not properly consult them. Although he had originally supported the bill, President Kagame ultimately changed his position arguing that Rwanda needed genocide laws that addressed the roots of the problem (Committee to Protect Journalists, 2002).

But then, all through the year 2001, "Rwanda officials bullied the state media and harassed independent journalists who accused them of overstating the genocide issue for their own gains," according to the Committee to Protect Journalists. "In this immensely Catholic country, reporters also got in trouble for writing bluntly about religious matters particularly in relation to the president" (Committee to Protect Journalists, 2002). A producer at Radio Rwanda, Gerard Mbanda was suspended for airing footage of Kagame, without his spectacles, being helped to locate a bible verse. Sources told the Committee to Protect Journalists that "those images could have been construed as suggesting that Kagame was incapable of reading the bible without help" (Committee to Protect Journalists, 2002). The message was clear: under the doctrine of tight information control any image that didn't flatter the president's persona would not be tolerated.

Then came the year of transition - 2003 - when Rwandan's voted for a new constitution and Kagame won an election in which his only real challenger, former premier, Faustin Twagiramungu had been so frustrated and harassed that he couldn't stage much of a campaign. Before the vote, the International Crisis Group had pointed out that:

Political parties have either been dismantled or forced to accept the consensus imposed by the RPF, the independent press has been silenced, and civil society forced to exist between repression and coercion. The RPF wields almost exclusive military, political and economic control and tolerates no criticism or challenge to its authority. The opposition has been forced into exile, and anti-establishment speeches relegated to secrecy. In the name of unity and national reconciliation, the various segments of Rwandan society are subjected to a paternalistic and authoritarian doctrine and cannot express themselves freely (International Crisis Group, 2002). 
At the end of the transition period, the new constitution appeared to make provision for a liberal media landscape in Rwanda, stating under Article 34 that:

Freedom of the press and freedom of information are recognized and guaranteed by the State. Freedom of speech and information shall not prejudice public order and good morals, the right of every citizen to honour, good reputation and the privacy of personal and family life. It is also guaranteed so long as it does not prejudice the protection of the youth and minors. The conditions for exercising such freedoms are determined by law (Republic of Rwanda, 2003, p. 9).

Even before the adoption of the constitution, a press law had been passed, which was "relatively permissive" (Frère, 2007, p. 97). Article 10 of $\operatorname{Law} N^{\circ} 18 / 2002$ proclaimed that "the press is free" while Article 11 stated emphatically that "censorship is not allowed” (Republic of Rwanda, 2002, p. 4) Many observers welcomed this provision as marking a new era in media freedom and development in Rwanda. In reality, however, the regime was unwilling to implement its own laws. The transitional regime's "repressive tactics against the independent press" in the years following the genocide had created an environment in which journalists had little room to operate as freely as the laws said they could (Committee to Protect Journalists, 2004).

In this environment, journalists and other civil society actors were faced with three choices. The first option offered peace of mind to those journalists who would do as the government wanted, refrained from criticizing, challenging or questioning government policy. Most of Rwanda's journalist chose this option. The second option involved the risk of harassment, imprisonment or even death for those journalists who saw things differently from the government's view and dared to express their opinions beyond the secrecy of their bedrooms. Only the most stubborn and optimistic chose this option. The first transitional president, Bizumungu, having survived the genocide and filled with so much optimism, chose this second option and stayed on in the country. "We believed that things would change with the RPF," he 
said in an interview. "We have been deceived," he lamented even as he proclaimed that he was prepared "to pay the highest price" (quoted in Reyntjens, 2004, p. 193). By the end of 2004, he was languishing in jail - lucky enough to be alive, but deprived of most of his freedoms, shamed and tamed. The final option, usually for those who had come to the realization that they were about to be killed or made to "disappear," simply involved packing bag and baggage and clandestinely moving across the border, most frequently, into Uganda.

For most observers, the excesses of the regime during the transitional period - including the wars in the Congo and the internal suppression of expression - may have seemed justified, even excusable. This was a historically complex country that had suffered a massive, bloody internal trauma and now in the hands of a guerrilla movement led by people who had been out of the country for so long. Some didn't even know Rwanda well enough. It was a very complicated situation. Add the "moral righteousness" the regime claimed for ending the genocide (Pottier, 2002, p. 63) to the complexity and the enormity of what was required to get the nation back on its feet and many were those who must have felt that the post-genocide regime deserved a carte blanche to do whatever it deemed necessary to stitch the nation back together. Mistakes would be made, there might be occasions when the regime would come across as heavy-handed, but there was hope that by the end of the transitional period the excesses would diminish and Rwanda would be on the democratic path, moving slowly, but surely and peacefully towards reconciliation and reconstruction. As Pottier puts it, the prevailing sentiment at the time was that, the regime's hardline position "could be justified as unfortunate but necessary for the common good" (Pottier, 2002, p. 58).

As a result "certain journalists acted as scribes for the RPF's rewriting-of-history project" (Pottier, 2002, p. 64). These were both Rwandan and international journalists, who were either co- 
opted by the regime or fell for its "sophisticated, well-rehearsed way with the media" (Pottier, 2002, p. 71). They were the journalists who were "less likely to ask awkward questions of the RPF, at least for a while, and more likely to embrace its interpretation of the struggle" (Pottier, 2002, p. 63). Ultimately, "the media [both local and international] paid a high price for the moral legitimacy it granted Kagame... [realizing] only too late they had fallen victim to Kagame's powerful doctrine of information control" (Pottier, 2002, p. 81).

By the end of the transition, therefore, post-genocide Rwanda's first democratically elected government was enjoying unbridled impunity (see Reyntjens, 2004), its hand strengthened by its own self-proclaimed moral righteousness, a decent economic performance and the failure of the international community to attach demands for increased freedom as conditions for its financial support. It turned out that "despite its civilian appearance, Rwanda [had become] an army with a state rather than a state with an army and it is effectively run by a military regime" (Reyntjens, 2010, p. 15).

In this context, the government after the transition didn't treat dissenting political and civic voices, including those of journalists, any better than it did in the transitional period. Cloaked in "democracy" and enjoying near-unconditional support from the international community, the government proceeded to build a regulatory framework that satisfied its "desire to control people and space" (Reyntjens, 2010, p. 17). This meant that the structures and institutions of democracy would be used quite cleverly not only to prop up and legitimize an authoritarian regime, but to also justify its repression as lawful. Having engineered the election of a legislature which was nothing more than a rubber stamp (see Reyntjens, 2004; Nyamwasa et al, 2010; Sebarenzi, 2011), it was easy to get the doctrine of information control cemented in law. 
So willing was the legislature to please the new president that at one point it appeared to have gone rather too far, even in the new president's eyes, by passing a bill that recommended the death penalty for journalists convicted for participating in the genocide. As stated earlier, Kagame declined to sign the bill into law. When the necessary amendments were made, $\operatorname{Law} N^{\circ} 18 / 2002$, provided severe penalties for journalists who fell afoul of its stipulations. Even newspaper vendors who sold publications with contents the government deemed offensive risked prosecution. In the situation where many critical journalists were publishing in Uganda, these provisions appeared to have the objective of ensuring that exiled dissident opinions remained outside Rwandan territory. The law also made provision for the seizure of journalists' "documents and audio visual equipment" but, worded rather vaguely, "only through legal proceedings without prejudice to judgment on the facts of the matter" (Republic of Rwanda, 2002, p. 20).

The law also permitted the licensing of private broadcast networks and established the High Council of the Press (HCP) - later renamed as the Media High Council. This was a government agency attached to the office of the president and ostensibly mandated to, among other things, protect press freedom and improve the quality of journalism in Rwanda (Frère, 2009). But many journalists saw the HCP as doing nothing other than helping the government to suppress them by making life difficult for those who stepped out of the official line. Responsible for accrediting journalists and granting media licenses, the HCP frequently recommended the suspension of journalists and/or their newspapers.

In one case in 2004, for example, the HCP recommended the suspension of Charles Kabonero of the Umuseso newspaper. This was after he had refused to name the source of a story which suggested a power struggle within the ruling party. Some media professionals "condemned the council as dysfunctional, accusing it of folding its arms in the face of aggression and arbitrary 
censorship affecting journalists on some publications," according to Frère. "Other journalists... deplored the propensity of some politicians to interfere in the affairs of the HCP in order to try and get rid of some particular journalists" (Frère, 2009, pp. 345-346). The HCP, therefore, was for a long time the first instrument for policing the media landscape and keeping it free of elements the government considered to be bad influences.

Besides the HCP, the government made sure that several other laws were passed which left journalists in no doubt, according to Nik Gowing, that "the Rwandan government could make life unpleasant" for them (quoted in Reyntjens, 2010, p. 26). These laws all but rendered certain subjects taboo and took them out of the spectrum of issues that could be openly discussed and debated. As was the case during the transitional period, it continued to be illegal to openly speak about the two main ethnic identities in Rwanda (Hutu and Tutsi). This is often justified as a worthy policy to nip the discrimination that culminated in the genocide in the bud. But it has also proven to be as much a part of the government's "rewriting-of-history project" (Pottier, 2002, p. 64) as well a subtle, calculated effort to mask the fact that Rwanda is now essentially being run by a minority clique from within the minority ethnic group, "the new Akaqu:"

While it officially rejected ethnic discrimination and even the notion of ethnicity, the RPF rapidly reserved access to power, wealth and knowledge to the Tutsi. The only exception was the cabinet where a number of Hutu served as ministers in order to give a symbolic expression of national unity... Of course, the elimination of ethnicity is a worthwhile goal shared by many Rwandans, but the cynical manipulation of this objective as a tool for the monopolization of power in the hands of a small group is something quite different (Reyntjens, 2004, p. 187).

This is a view shared by Nyamwasa et al - four Tutsi men who claim to have fallen out with the current regime because of their concerns over the concentration of power in the hands of the "the new Akazu:" 
The core group that controls the Rwandan state does not represent or even act in the best interest of the entire Tutsi community. There are many in the Hutu community who are not beneficiaries of the political system that prevails in Rwanda. Nevertheless, it is fair to say that the Rwandan government is dominated by the Tutsi minority. The Tutsi constitute the inner circle that wields real power in Rwanda... Rwanda has two parallel governments, an informal one and a formal one. The formal government is controlled by the informal one (Nyamwasa et al, 2010).

These are views Nyamwasa et al could not have expressed in Rwanda itself, since public references to the ethnic groups are not permitted under most circumstances. The law prohibiting references to ethnicity was one of the first pieces of legislation most often used to punish journalists and civil society activists in the years following the transitional period. Laws against disrespecting the president and other higher public authorities were also passed and used to stifle free expression. But then came the all-embracing law on "genocide ideology," legislation so broad that it could be used to prosecute any conduct any government official considered offensive. Investigating atrocities committed by the military was genocide ideology. Calling for justice for any section of society could be considered genocide ideology. Writing about alleged corruption became genocide ideology as was any suggestion that the government was not delivering on its promises. The scope of the law on genocide ideology was almost boundless.

Long before it actually became law, government officials had taken to evoking this fearsome notion of genocide ideology to stifle and, in cases where some people proved almost impossible to stifle, punish dissent. As mentioned earlier, the government started the accusations of genocide ideology just before the first post-genocide presidential and parliamentary elections in 2003. This followed the publication of a parliamentary committee report, which recommended a ban on the main opposition party, which, the committee claimed, was pursuing a genocide ideology. "The senate report [conflated] genocide ideology with any ethnic discourse, political 
criticism, revisionism and negationism," Waldorf writes. "According to its definition, any mention of alleged RPF war crimes or human rights abuses constitutes genocide ideology" (Waldorf, 2011, p. 54). Two years after "genocide ideology" became enshrined in Rwandan law Amnesty International noted that this and other laws ostensibly aimed at eliminating ethnic discrimination are so "broad and ill-defined" that they "have created a vague legal framework which is misused to criminalize criticism of the government and legitimate dissent:”

The cumulative result of these laws is to deter people from exercising their right to freedom of expression. This chilling effect means that people who have yet to have any action against them nonetheless fear being targeted and refrain from expressing opinions which may be legal. The laws have had a corrosive effect on mutual trust in a society already fragile after the 1994 genocide and run counter to the government's stated commitment to national unity (Amnesty International, 2010, pp. 7-8).

In this context, owners and managers of newly licensed broadcast stations decided to guard their investments by staying away from news and commentary. "The public radio and television are there for relaying the action of the government," the information minister declared when the first private broadcast licenses were issued in 2003. "The private media, rather, should be interested in other things, like music and entertainment" (quoted in Waldorf, 2007, p. 411). The minister's advice (or warning) was heeded and Rwanda's privately-owned radio stations have since taken to the safe arenas of sports, entertainment and business reporting (see Gasore, 2013, March 02).

The print media, on the other hand, has been a little more daring, even though many of Rwanda's newspapers are said to be aligned in one way or another with the government. As was the case in the transitional period, those print journalists who are critical of the government continue to pay dearly for opposing or challenging the government. In 2002, the Ugandan-born Tutsi editor of The Rwandan Herald was deported for writing an editorial calling for the release of the imprisoned former president, Pasteur Bizumungu (Waldorf, 2007, p. 409). In the same year, 
the editors of Ubuntu were charged with endangering state security and divisionism "for using the word 'ubuyanja' (spiritual renewal) in their masthead (ibid.). The Committee to Protect Journalists reported in 2004 that "private publications that have tackled sensitive subjects, such as the war in neighbouring Congo, government corruption or election irregularities continued to face harassment" (Committee to Protect Journalists, 2004).

Many observers point to Umuseso as the one newspaper which has been the most frequent victim of such government harassment. Waldorf describes Umuseso as "a lively, provocative and occasionally partisan weekly that [publishes] critical articles about the government and broke stories on government corruption" (Waldorf, p. 2007, 409). "Often carrying rumour, opinion and unverified sensationalist news, [Umuseso] has a dangerous style that regularly flouts professional standards," according to Frère (2009, p. 99). The paper has also been described as "the only independent voice in the Rwandan media" (Committee to Protect Journalists, 2003). Thus the journalists at Umuseso were among the very few citizens in Rwanda who dared to publicly criticise the government and expose its shortcomings. Over the years, therefore, the relationship between the government and Umuseso can best be compared with a high stakes game of cat and mouse. In 2002, for example, a government minister said Umuseso was no different from Kangura, the pregenocide extremist pamphlet. A year later, a parliamentary commission described Umuseso journalists as "propagandists of divisionism" and in 2004, yet another parliamentary commission accused the paper of inciting the population "to civil disobedience against the government" (quoted in Waldorf, 2007, p. 409).

By the end of 2005, the newspaper was struggling to survive after most of its journalists fled into exile. It was also facing severe financial difficulties following a government directive to state agencies to stop placing advertisements in the paper. Cutting advertising revenue to 
newspapers deemed to be on the side of "negative forces" therefore became part of the government strategy for taming journalists.

As the advertising lifeblood was squeezed out of Umuseso and its journalists were forced to flee into exile, Jean-Léonard Rugambage burst onto the Rwandan media scene as deputy editor of Umoco. By this time, it was being reported that:

The arrival of private radio stations did little to improve the climate for media in Rwanda, where repression by the government of President Paul Kagame and selfcensorship by journalists all but stifled critical coverage. Local media and human rights groups often failed to speak out against intimidation and attacks on the press. Previous acts of violence against journalists remained unpunished... International human rights groups and independent observers expressed concern that genocide allegations were being used in some cases to settle personal scores and to punish government critics, including journalists (Committee to Protect Journalists, 2006).

Rugambabe's first confrontation with the authorities involved an accusation that he had participated in the genocide. This was after he had published a story alleging corruption and witness tampering in a community (or gacaca) court prosecuting genocide suspects. "Evidence against Rugambage appeared flimsy" (Committee to Protect Journalists, 2006), yet one of the gacaca courts found him in contempt for questioning the impartiality of the presiding judge. For the contempt conviction, he was sentenced to a year's imprisonment while the substantial genocide charge remained outstanding.

As Rugambage served his jail term, Kigali-based reporters for the BBC and VOA were attracting the government's ire for filing reports on assessments of the human rights situation in Rwanda by Amnesty International and Human Rights Watch. Government officials made it clear that they would look into the two reporters' "ideology." A few months after this announcement, armed men attacked the brother of the VOA correspondent, "telling him the attack was a response to her broadcasts" (Committee to Protect Journalists, 2007). Meanwhile, the editor of 
Umuvugizi, Jean Bosco Gasasira reported that he had received "threatening phone calls" after writing about corruption in the government (ibid.). A few months later he was physically attacked by armed men who "broke [his] left hand and smashed his head, arms and legs while shouting their intent to ensure that he could not write again" (Committee to Protect Journalists, 2008).

After several months in treatment, Gasasira went back to work but was subjected to intimidation and incessant police interrogation. After one such session with the police, he told other journalists that he was "happy because he was summoned by the police instead of being beaten up with iron bars" (Committee to Protect Journalists, 2008). In the meantime, the independent media continued to suffer the government's advertising squeeze, with President Kagame proclaiming that "it [was a] waste of taxpayers' money for the government to continue advertising in publications that relentlessly write only negative things about it, without recognizing the good things it is doing" (ibid.). In the same year, 2007, a radio reporter was dismissed and later charged with "genocide ideology" for interviewing a Hutu Christian priest who claimed he had saved dozens of Tutsi lives during the genocide.

A year later, the editor of Umuco, Bonaventure Bizumuremyi, himself a victim of government harassment and intimidation fled into exile "to avoid persecution" after criticizing President Kagame in an editorial. The publication claimed that the president's days in office "were numbered" and suggested that the head of state would "face an international tribunal, be forced to live in exile or commit suicide like Hitler" (Committee to Protect Journalists, 2009). After the closure of Umoco, Jean-Léonard Rugambage teamed up with Jean Gasasira on Umuvugiri, a newspaper struggling to remain independent and critical.

With another presidential election a few months ahead, parliament passed a law in 2009, which, among other stipulations, prohibited criticism of the president or the army. The law also 
contained provisions that would force journalists to reveal their sources in court. "It is not a law," Gasasira lamented "but a death sentence for journalism in this country" (quoted in Committee to Protect Journalists, 2011). Shortly, after this comment, Gasasira (his paper banned) fled into exile. Kagame declared later at a campaign rally that "those who give our country a bad image can take a rope and hang themselves" (quoted in Committee to Protect Journalists, 2011). The government then "shut down the nation's two leading independent weeklies, silenced several other news outlets in the weeks before the vote and harassed critical editors in court" (Committee to Protect Journalists, 2011).

It was around this time that an assassin tried to kill the Rwanda's former army chief, Kayumba Nyamwasa, who had been living in exile in Johannesburg. As he lay in hospital in critical condition, Nyamwasa's wife directed her suspicions at the Rwandan government for the assassination attempt. "I think it was our government," Rosette Nyamwasa reportedly said. “President Kagame] must be behind it. He wants us dead ... I don't have proof but we've been harassed for such a long time" (quoted in Smith, 2010, June 21). The government in Kigali denied any involvement and described Mrs. Nyamwasa's allegation as "preposterous" (The Economist, 2010, June 24).

But the matter was of such great interest to Rwandans that one journalist decided not to take the government's denial as the final word. Jean-Léonard Rugambage, deputy editor of the Umuvugizi newspaper, claimed that his investigations suggested there was some truth to the allegations of government involvement in the attempt to kill Nyamwasa. A day after publishing his report online, Rugambage was himself attacked and killed in front of his house. His colleagues blamed the government for his death. "This was not an accident," Umuvugizi's senior editor, Jean Bosco Gasasira, speaking to the VOA from exile in Uganda, claimed. "[Rugambage] had spoken 
to me all week, informing me about surveillance on him" (quoted in Kron, 2010, June 25).

Rugambage's friends lamented his refusal to move into exile like dozens of his professional compatriots and political dissidents had done.

President Kagame would go on to win the election in 2010, after his main challenger, Victoire Ingabire, was imprisoned for "genocide ideology." In the same year, two journalists, Agnès Uwimana and Saïdati Mukakibibi, were respectively sentenced to 17 and seven years imprisonment for violating the country's media laws. They had been convicted for crimes ranging from insulting the president to genocide denial. This was Uwimana's second jail stint in three years, having been jailed in April 2007 for publishing a reader's letter in Umurabyo, “comparing ethnic killings during Kagame's regime to those under the rule of the previous Hutu regime" (Committee to Protect Journalists, 2008).

The murder of Rugambage, the assassination attempt on Nyamwasa and the imprisonment of Uwimana and Mukakibi and the authorities' refusal to allow Ingabire to run against Kagame, coupled with the steady stream of Rwandan's fleeing into exile, prompted searching questions about the fairness of the polls. There were concerns that the Kagame regime was basking in impunity and jeopardizing peaceful reconciliation and co-existence as well as the future of Rwanda. Reyntjens described the election as a "façade," pointing out that the Media High Council's release of "a list of media outlets authorized to cover the poll” excluded all of Rwanda's "major independent outlets" and that "the RPF's silencing of the media revealed a deep sense of insecurity" (Reyntjens, 2011, pp. 66-67).

It was after those elections that four of Kagame's ethnic kin (exiled former key members of his inner circle), published the damning 'Rwanda briefing' pointing out that "the image of 
Rwanda as a democratizing, reforming and stable post-genocide country does not reflect reality."

They also claimed that "Rwanda is far less free now than it was prior to the genocide:"

The law guarantees freedom of the press, but the media remains tightly controlled by the government. Media outlets are either state-controlled, co-opted or constantly under siege. The government has used curbs on the media to suppress criticism and dissent. The security services sometimes co-opt independent journalists by bribing them with money. Journalists who refuse to toe the line or be co-opted have often been subjected to threats and intimidation. The Kagame government uses trumped up criminal charges to intimidate journalists who express dissenting or critical views (Nyamwasa et al, 2010).

For their effort, the authors of the "Rwanda briefing," were tried in absentia on various charges and sentenced to prison terms ranging from 20 to 24 years. By this time, the suppression of dissent had become so alarming that, at least, one of the regime's most avid praise-singers was compelled to speak out. Stephen Kinzer, who had written a book praising Kagame for putting Rwanda on its feet - The Economist described the publication as "hagiography" (The Economist, 2008, August 21) - wrote in The Guardian that 'Kagame's authoritarian turn risks Rwanda's future:"

No authoritarian leader cedes power easily, or turns it over to bodies he cannot control. This is especially true of leaders who come to power by guerrilla war, as Kagame did. Guerrilla leaders win wars by being paranoid and ruthless. Once they take power, they are expected to abandon those qualities and embrace opposite ones: tolerance, compromise and humility. Almost none manages to do so. Kagame has proven himself to be a visionary figure in some ways, so there seemed hope that he would be an exception. Events of recent weeks suggest otherwise (Kinzer, 2011, January 27).

These sentiments were echoed by Longman:

The regime tolerates very little public criticism, strictly limiting freedoms of speech, press, and association. Political parties are restricted and intimidated, while constraints and manipulation of the electoral process have prevented elections from being truly free and fair. Defenders of the RPF regime simultaneously deny these criticisms and claim that the restrictions on freedoms are necessary for national unity, given the history of genocide and that benign authoritarian rule is necessary for economic development, their top priority. Rwanda's persistent 
authoritarian rule may ultimately prove disastrous for the country's long-term stability, as it prevents the public from expressing its interests through productive, peaceful political means and also prevents the regime from benefiting from the contributions of much of the population (Longman, 2011, p. 27).

A year into his second term in office, it appeared Kagame and his regime were in the mood for reform. A raft of new legislation was placed before parliament, promising to expand the frontiers of free expression while allowing journalists more room for manoeuvre. Even as the new laws were under consideration in parliament, a radio presenter was being prosecuted on a charge of genocide ideology for "apparently mistakenly" (Human Rights Watch, 2013) mixing up the Kinyarwanda words for "victims" and "survivors" in a news broadcast (see also Noorlander, 2013). Another journalist was severely assaulted to the point of unconsciousness by security officers who accused him of trying to gain access to a parliamentary committee sitting without authorization (see Human Rights Watch, 2013).

The new media law and allied legislation came into force in March 2013 with the progovernment New Times newspaper hailing them as a "grand victory" for the Rwandan media (Agutamba, 2013, March 13). The law aims to determine "rights obligations, organization and functioning of media in Rwanda for the general interest" (Republic of Rwanda, 2013, p. 33). It retained the prohibition on censorship, while recognizing the rights of journalists. These rights include the right to establish a media company and respect for the confidentiality of sources even though judges retain the power to compel journalists to name their sources. The law also obliges journalists to respect the public's rights of correction, reply and rectification. Judges could also order the seizure of a journalist's equipment and documents. The new law also makes it possible for freelancers to operate more freely in Rwanda than in previous years when journalists were required to be affiliated with a media organization. 
The new legislations also stripped the Media High Council of its regulatory powers, abolished the requirement for journalists to attain a certain level of education and set up "a media self-regulatory body." This would be "an organ set up by journalists themselves whose responsibility is to ensure compliance with the principles governing media and to defend the general interest” (Republic of Rwanda, 2013, p. 37). Rwandan journalists would be required to obtain accreditation from this self-regulatory body to be able to work within the country. Foreign journalists, on the other hand, "shall be given accreditation by a competent public organ" (Republic of Rwanda, 2013, p. 38).

In addition to the new media law, parliament also passed an access to information bill which would "enable the public and journalists to access information possessed by public organs and some private organs" (Republic of Rwanda, 2013, p. 70).

These legislative reforms were cautiously welcomed as a positive step forward for media development in Rwanda. But even as they welcomed the new laws, many activists were quick to point out that the new laws were woefully inadequate. For example, the NGO, Article 19, was concerned that "the state retains control of the media through a series of authoritarian requirements," pointing out their lack of "clarity" on a number of vital areas (Article 19, 2013, March 18). For his part, Peter Noorlander, whose organization, the Media Legal Defense Initiative, had been offering legal support to some of Rwanda's persecuted journalists asserted that:

The introduction of a set of new laws, unconnected with the offences for which journalists have been convicted, cannot be called a first step. Journalists have been jailed for criminal libel, alleged national security offences and vague genociderelated laws. If the Rwandan government genuinely wants to liberalise the environment in which the media operates then the real first step is to release the journalists unjustly imprisoned and reform the laws that led to their imprisonment to begin with (Noorlander, 2013, March 20). 
Noorlander is referring here to the laws on genocide ideology, which had been used for several years to prosecute and persecute journalists. Human Rights Watch seemed to support Noorlander's position by raising concerns that even in its revised form the law on genocide ideology "retained language that could be used to criminalize free speech" (Human Rights Watch, 2014).

All this, therefore, seemed to suggest that the Rwandan government was offering a few new freedoms to journalists and other players in the "public sphere," which the German theorist, Jürgen Habermas, defines as "a realm of our social life in which something approaching public opinion can be formed" (1974, p. 49). But it was at the same time retaining the right to restrict the enjoyment of several other important freedoms. Thus, the NGO, Article 19, asserted that the "the law fails to meet international standards" and urged the Rwandan government to "undertake a review of the "divisionism" and "genocide ideology" laws, to bring them into line with international standards on freedom of expression, and to decriminalize defamation" (Article 19, 2013, March, 18).

Recent events as Rwandan prepared to commemorate the $20^{\text {th }}$ anniversary of the genocide highlighted the government's unwillingness to live up to its constitutional responsibility of guaranteeing free expression and to allow scrutiny of its policies and practices. Much of it started at the beginning of 2014, when Rwanda's former intelligence chief Patrick Karegeya, one of the co-authors of the "Rwanda briefing" was found dead in a hotel room in Johannesburg. This was followed by yet another attempt to kill Nyamwasa, also a co-author of the "Rwanda briefing." South Africa expelled two Rwandan diplomats for alleged involvement in the assassination of Karegeya and the repeated attempts to kill Nyamwasa. While offering little detail, the South 
African foreign minister, Jeff Radebe, said the Rwandan diplomats were expelled because they had violated their diplomatic status by associating themselves with "illegal activities that have taken place where there were attempted murders, including a murder" (quoted in BBC, 2014, March 12). Rwanda responded in a tit-for-tat fashion by expelling six South African diplomats while demanding proof that its envoys had engaged in illegal activities in Johannesburg.

The diplomatic crisis sparked by the assassination of Karageya and the attempts on Nyamwasa's life inadvertently exposed one of the Rwandan regime's sinister modes of responding to journalistic work it considered unfavourable. An American journalist, Steve Terril, was denied entry into Rwanda when he arrived at Kigali airport to cover the commemoration of the $20^{\text {th }}$ anniversary of the genocide. This was after he had exposed the fact that some aggressive postings on the microblogging site, Twitter, against the French journalist, Sonia Rolley, had originated from the office of the president:

The strange case began with Sonia Rolley, a Radio France Internationale journalist reporting on the deaths of Rwandan dissidents. [Rolley] was bullied for months on Twitter by an account with the handle@RichardGoldston - apparently a reference to Richard Goldstone, the first UN prosecutor for Rwanda, though it had no connection to him. During one bitter exchange Terrill intervened to demand that@RichardGoldston stop the "misogynistic harassment" of Rolley. A response then came not from @RichardGoldston but from [President] Kagame’s official Twitter account, which has 292,000 followers. Observers seized on the apparent slip of the keyboard as evidence that the person responsible for the aggressive tweets was close to Kagame and acted with his blessing. As the controversy grew, the presidency was forced to admit in a tweet: "@RichardGoldston was an unauthorised account run by an employee in the presidency. It has been deleted and the staff member reprimanded" (Smith, 2014, March 20)

This incident highlighted the Rwandan government's strategy of using every available means to frustrate journalists and silence unfavourable voices, with Susan Thomson, a Canadian academic pointing out that: 
Rwanda's Twitter-gate raises questions about the central role of RPF Twitter-trolls in calling out foreign journalists who seek to hold it to account for its excesses at home and abroad. President Kagame's reactionary tweets provide insight into the political reality behind his government's carefully crafted narrative that Rwanda is a nation rehabilitated from the ruin of the 1994 genocide. Twitter-gate is also illustrative of the harassment and intimidation which critics of the RPF regime regularly experience (Thomson, 2014, March 17).

With the country's very unique and traumatic history, the Rwandan government has often responded to such criticism with assertions that it is doing its best under very trying and difficult conditions to balance the ideals of free speech with the need to nip hate speech in the bud and stop it from breaking Rwandan society apart. "We are operating in a very different context," Kagame has said. "A nation that has just experienced genocide? There is no instruction manual for this" (quoted in Chapman, 2011, June 9). But critics assert that the regime’s best efforts have not been good enough. They point out that harassing, imprisoning and (allegedly) killing journalists and suppressing free expression goes against the spirit of the Rwandan constitution, which clearly guarantees press freedom and could possibly lead to renewed conflict.

While it is true that few examples exist for fixing the broken nation Rwanda was in 1994, there is one nation which offers Rwanda some useful lessons and models for reforming a media implicated in genocide and mass murder, making it a force for good. 


\section{Chapter 6}

\section{MODELS AND LESSONS}

Germany and its citizens have been making immense contributions to human civilization for hundreds of years. Gutenberg gave the world its first printing press in the $17^{\text {th }}$ century (Sandford, 1976, p. 1); Martin Luther's challenge of Catholic hegemony launched the Reformation and the Protestant movement (Fulbrook, 1993, p. 33); Karl Marx's strident criticism of class structure has influenced governance around the world (Fulbrook, 1993, p. 111) and the musical virtuosity of the likes of Bach, Beethoven, Händel and Brahms are significant markers of high culture and good taste (Kitchen, 2006, p. 7). Historically, the country that gave the world Goethe, Kant and Hegel has much to be proud of. But if there is one thing that makes Germans bow their heads in shame it is the holocaust in which more than six million Jews and countless other opponents of the Third Reich were murdered on the streets, in forests, hospitals and gas chambers across several European nations.

Jews were especially targeted in the holocaust because for centuries in Germany (and other European nations) they had been looked down upon as second-class citizens. Myths had been spawned and transmitted across generations about the Jews, who were variously branded as an evil and immoral race. "With their distinctive styles of dress and appearance, their different religious beliefs and practices, as well as their unique and easily disliked economic role, Jews had long been a target for vicious anti-Semitism” (Fullbrook, 1993, p. 89). Even Martin Luther was an anti-Semite. The leader of the reformation wrote in 1543 that:

[Jews] are nothing but thieves and robbers who daily eat no morsel or wear no thread of clothing which they have not stolen from us by means of their accursed usury... Such a desperate, thoroughly evil, poisonous, and devilish lot are these Jews, who for these fourteen hundred years have been and are still our plague, our pestilence and our misfortune (quoted in Bytwerk, 2001, p. 68). 
Hitler's National Socialists who presided over the holocaust made extensive use of Luther's sentiments. One of the main instruments in the Nazi propaganda machine, Der Stürmer newspaper had "The Jews are our misfortune" emblazoned on the front page of almost every edition (Bytwerk, 2001, p. 65; Luckert \& Bachrach, 2009, p. 88). Der Stürmer came into prominence after Germany's defeat in the First World War. It fiercely promoted the notion that the Jews (and to a smaller extent some other minority groups) had "stabbed [the country] in the back," contributing to its humiliation in the war, leading to the exacting reparations it had to make under the Treaty of Versailles (Luckert and Bachrach, 2009, p. 22). The vitriol the paper poured on the Jews was not entirely new in German (and the wider European) society, but it was more intense and with one central aim: to garner support for the "final solution" to what had been termed "the Jewish problem” (Fullbrook, 1990, pp. 196-198).

Moves towards adopting that "solution," started under the Nazis with the so-called Nuremberg Laws prohibiting "marriage and extramarital sexual relations between Jews and persons of German or related blood" (Luckert and Bachrach, 2009, p. 90). Starting insidiously, it was such state-sanctioned discrimination, hatred and harassment that ultimately culminated in the holocaust - mass murder on a grand scale, one of the worst demonstrations of humanity at its basest, Germany's shame.

About 60 years after the Jews were led like sheep into gas chambers, the extremist Hutudominated government in Rwanda orchestrated an orgy of mass murder in which Tutsi citizens were hacked to death with machetes and nail-studded clubs on the streets of the tiny East African nation. Many Hutu who refused to lend their support to the extremist government were also killed. The European holocaust and the African genocide happened five to six decades apart, in 
countries separated by six thousand miles of land and sea. Yet they share a very striking similarity in the manner in which journalists and other media workers were implicated (and later punished) as accomplices to mass murder.

After the holocaust, Julius Streicher, publisher of Der Stürmer, was convicted by the International Military Tribunal in Nuremberg for crimes against humanity. The judges noted that:

As early as 1938 he began to call for the annihilation of the Jewish race. Twentythree different articles of Der Stürmer between 1938 and 1941 were produced in evidence, in which extermination "root and branch" was preached. Typical of his teachings was a leading article in September, 1938, which termed the Jew a germ and a pest, not a human being, but "a parasite, an enemy, an evildoer, a disseminator of diseases who must be destroyed in the interest of mankind." Other articles urged that only when world Jewry had been annihilated would the Jewish problem have been solved and predicted that fifty years hence the Jewish graves "will proclaim that this people of murderers and criminals have after all met its deserved fate"... With knowledge of the extermination of the Jews in the occupied Eastern territory, [Streicher] continued to write and publish his propaganda of death (International Military Tribunal, 1946, p. 120).

Streicher was hanged in October 1946. But a co-accused who used to broadcast Nazi propaganda messages on radio, Hans Fritzsche, was sentenced to just nine years imprisonment. The sentence, though, was later reduced, making it possible for him to walk free in 1950. The judgment on Fritzsche noted that he:

Sometimes made strong statements of a propagandistic nature in his broadcasts but the tribunal is not prepared to hold that they were intended to incite the German people to commit atrocities on conquered people, and he cannot be held to have been a participant in the crimes charged. His aim was rather to arouse popular sentiment in support of Hitler and the German war effort (International Military Tribunal, 1946, p. 150).

Luckert and Bachrach believe Fritzsche, considered a low-ranking Nazi operative, "probably ended up as a defendant along with the other more senior German officials because [the Nazi propaganda minister's] death had left the Allies without a senior representative of the Ministry of Public Enlightenment and Propaganda, and the Western Allies were eager to appease the Soviets" 
(p. 158). In his dissenting opinion with the general verdict on Fritzsche, the only Soviet judge on the tribunal panel, Major General I. T. Nikichenko, declared that "the dissemination of provocative lies and the systematic deception of public opinion were as necessary to the Hitlerites for the realization of their plans as were the production of armaments and the drafting of military plans" (quoted in Luckert and Bachrach, 2009, p. 158).

The Nuremberg judgment on both Fritzsche and Streicher were cited as the main precedent in the media trial of the International Criminal Tribunal for Rwanda sitting in Arusha, Tanzania, in 2003. The tribunal in Arusha made specific references to the trial of Streicher, concluding that what happened in Rwanda was almost a repeat of what had happened under the Nazis in Germany:

The chamber notes that Julius Streicher was convicted at Nuremberg of persecution for anti-Semitic writings that significantly predated the extermination of Jews in the 1940s. In Rwanda, the virulent writings of Kangura and the incendiary broadcasts of RTLM functioned in the same way, conditioning the Hutu population and creating a climate of harm as evidenced in part by the extermination and genocide that followed (Pillay et al., 2003, p. 303).

Just as it was in Nuremberg, the Arusha tribunal was hard pressed to find a direct causal link between the media output and the murderous orgy on the streets. But the judges sitting in Tanzania, unlike in the case against Fritzsche, found the Rwandan journalists "guilty of conspiracy to commit genocide" and sentenced them to lengthy prison terms, stressing that:

Freedom of expression and freedom from discrimination are not incompatible principles of law. Hate speech is not protected speech under international law. In fact governments have an obligation under international law to prohibit any advocacy of national, racial or religious hatred that constitutes incitement to discrimination, hostility or violence. A great number of countries around the world, including Rwanda, have domestic laws that ban advocacy of discriminatory hate, in recognition of the danger it represents and the harm it causes (Pillay et al, 2003, p. 303). 
While this point cannot be denied, the government of Rwanda has increasingly come in for criticism for the manner in which it polices and punishes speech under various pretexts, almost all ostensibly aimed at preventing discrimination and eliminating hate speech. Rwandan government officials who grant interviews to the foreign media are often put on the defensive as they face a barrage of questions about media freedoms in the country. Peter Noorlander is a typical critic of the Rwandan government's media regulations, condemning the government for making journalists in the country treat a range of issues as taboo subjects:

Particular issues to be avoided include rifts within [President] Kagame's party, the Rwandan Patriotic Front, deteriorating political freedoms, speculation regarding Kagame's alleged involvement in the shooting of a dissident Rwandan general [Nyamwasa] in South Africa in June of [2010] and the murder of a journalist [the Rugambage case in July 2010], as well as any mention of the relationship between Hutu and Tutsi. The very use of these labels is frowned upon, and discussion of the relationship between the two will lead to a prosecution and very likely incarceration under Rwanda's "Law relating to the punishment of the Crime of Genocide Ideology" (Noorlander, 2010, August 9).

With many journalists in prison or fleeing the country into exile, even recent amendments to Rwanda's media laws have failed to impress the likes of Noorlander who insists that a lot more remains to be done to unshackle the Rwandan media.

President Kagame, however, sees Rwanda’s media laws as necessary for the country to break with its past of ethnic animosity. "Rwandans will not tolerate voices that promote a return to the ethnic divisionism that precipitated the genocide," he says. "To that extent, we place limits on freedom of expression in a similar way to how much of Europe has made it a crime to deny the Holocaust. Aside from that, Rwanda is a very open and free country" (quoted in Smith, 2012, October 10).

In one sense Kagame is right. The laws in Rwanda make it a crime to deny the genocide just as it is a crime in Germany to deny the holocaust. Furthermore, much of the world frowns at 
anyone who challenges the fact that the holocaust happened. Beyond that, however, Kagame's claim about Rwanda being an "open and free country" is what gets human rights groups and free speech advocates rolling their eyes. It is difficult to see how a country that jails people for talking about their ethnicity (the core of their identity) can claim to be "open and free." This is also a very poor description of a country where radio stations "are essentially devoted to entertainment and to magazine programmes focussed on social, development or religious issues [with] little general or political news" (Frère, 2009, p. 344). A country where "the government forbids [news] coverage of... institutions such as the military, the Justice Department and the State House" (Kalyango, 2011, p. 16) is anything but free.

To mounting criticism about his alleged oppression of the media and suppression of dissent, President Kagame responds:

I don't think anybody in any human rights organization can claim to have contributed to human rights more than me. There is none. I have saved children, I have empowered women. I have actually fought repression and dictatorship and won over it and powered the people.... These people who talk about human rights, I don't know what they mean when I have enabled Rwandans to put food on the table and each can fend for themselves (quoted in Perry, 2012, September 14).

With these words, Kagame is referring to the fact that the military victory of his guerrilla forces brought an end to the genocide. It also made it possible for thousands of Rwandans (and their descendants) who had been living in exile for decades to return home, escaping trying conditions in refugee camps and discrimination in foreign lands. After the war (and the genocide), however, comes the enormous task of forging a state, securing its borders, seeing to the well-being of those within its boundaries and building the institutions to help them live in harmony.

Nation-building is not an easy task anywhere on earth. It is particularly difficult in places where prejudice and animosity have been expressed in violence, leading to the loss of hundreds of 
thousands of lives. So the task facing Kagame and his administration is a complex one. But it is not the first time a group of human beings have been faced with the difficult task of rebuilding a nation torn apart by genocide. And for Rwanda, Germany offers, perhaps, the best example that it is possible to bring a nation back to its feet without suppressing dissent and criticism. Germany, therefore, is a good place to look to for lessons on how to build a media environment that contributes to nation building without stoking ethnic animosities.

The regime in Rwanda needs to cast its vision further afield instead of maintaining a narrow focus on the crime of genocide ideology (or denial). At the same time, the regime may need to device strategies aimed at helping Rwandans to use their differences to build a strong tapestry of nationhood that can withstand the evil machinations of a few politicians. Such a broader view could incorporate the situation in Germany after the defeat of the Nazi regime, drawing some useful lessons in constructing a democratic and responsible media out of a discredited media, which has been severely implicated in mass murder and crimes against humanity.

In a nutshell, the problem with the Rwandan government's media regulatory system is that in crafting them, the regime either failed, or was unwilling, to learn from the best example available to it - how the victorious Allies managed to reshape the media in Germany, stripping it of all Nazi propaganda elements without stifling free expression. A fuller appreciation of this point demands a brief examination of the media in Germany before the Nazi regime and after the end of the Second World War, when the Allies took charge of the country.

Sandford describes Germany as "the homeland of European journalism” (Sandford, 1976, p. 3). Between the $17^{\text {th }}$ century and the early parts of the $20^{\text {th }}$ century the country developed a vibrant press environment. There had been periods of severe censorship and there were times 
when the media could publish anything with very little, if any, interference from the various provincial and imperial regimes that constituted the entity known today as Germany. The newspapers represented a broad spectrum of ideas and political traditions, from the "party press," which were "published by or for a particular political group, as opposed to the "independents," with their absence of proclaimed permanent affiliations," according to Sandford, (1976, p. 8).

It was out of this tradition that Julius Streicher started publishing Der Stürmer "devoted entirely to rousing racial hatred," according to Bytwerk, who also points out that "a sign of [a] reputable German political party was the publication of a newspaper” (Bytwerk, 2001, pp. 1 \& 9). Der Stürmer was just such a newspaper for the Nazis, even though the party's official mouthpiece was the Völkischer Beobachter.

When the Nazis came to power, Hitler proceeded to nationalize every newspaper in Germany, effectively making every publishing house and the fledgling broadcast industry a mouthpiece of the Nazi regime. Hitler's Emergency Decree for the Protection of State and Nation and his "Editors Law," reduced journalists and their editors into "servants" of the state:

All areas of intellectual and cultural life fell under the control of Josef Goebbels' Imperial Ministry of Popular Enlightenment and Propaganda. This ministry contained a range of special departments supervising radio, cinema, theatre, literature, advertising and the press. In addition, all editors had to become members of a National Socialist Press Chamber from which all non-Aryans and anti-Nazis were automatically banned. Under such conditions, a form of selfcensorship naturally developed. Moreover, a subtle but near absolute effective control of news and information was brought about... Thus, during much of the Third Reich there remained a superficial appearance of 'pluralism' even under conditions of de facto Nazi Party monopoly and absolute control of information (Humphreys, 1994, pp. 22-23).

It was this stranglehold on the German media that made it possible for Nazi propaganda to spread so far, so quickly. Defining propaganda as "the dissemination of information whether truthful, partially-truthful, or blatantly false, that aims to shape public opinion and behaviour," 
Luckert and Bachrach point out that Hitler learned at an early stage that it was the one tool that would help him win - and stay - in power:

Drawing on modern advertising methods, the Nazi leader recognised that the propagandist, like the advertiser, had to sell an idea, a cause and an organization to the targeted audience as the best possible choice - not to encourage reflection or deliberation about alternatives (Luckert and Bachrach, 2009, pp. 2 \& 32, emphasis added).

Capturing and controlling the media, therefore, was essential to the Nazis' long-term objectives. It had helped to move them from the fringes of German politics to the very helm of the country and they were determined to use it to build a German society of pure Aryans, devoid of unwanted elements:

Propaganda publicly Identified who would be excluded from the new society and justified measures against the "outsiders": Jews, Gypsies (Roma and Sinti), homosexuals, political dissidents, and Germans viewed as genetically inferior or harmful to the "national health" (persons with mental illness or disabilities, or epilepsy, congenital deafness and blindness, chronic alcoholism, drug addictions and others)... Exploiting pre-existing images and stereotypes, Nazi propaganda portrayed Jews as an "alien race" that fed off the host nation, poisoned its culture, seized its economy and enslaved its workers and farmers (Luckert and Bachrach, 2009, p. 86).

With such depictions of minorities so pervasive in the media, the Nazis "did establish an attitude of indifference towards the Jews without which the holocaust could not have occurred," according to Bytwerk. "With no one willing to stand by the Jews, it became easy to kill them" (2001, p. 178). Fullbrook also points out that the first Nazi concentration camp was opened in 1933 "to much public fanfare, with enthusiastic newspaper coverage" and even for those the Nazi recognized as Aryans (true Germans), "fear of arrest, and fear of informers led to a frightened public conformity on the part of many Germans, who were forced to lead a double life, expressing their real views only in complete privacy" (Fullbrook, 1990, p. 181, emphasis added). 
It was this nation that the victorious Allies of the Second World War took over - a nation scarred by war; its shell-shocked people just coming to terms with the deceit of their recently deposed government, the economy of their nation in ruins. The Allies were faced with the problem of literally having to build a new state and its institutions from the rubble of the war they had just won and they recognized that reforming the media was as important in this effort as capturing Berlin and winning the war itself. What they built and how they went about it provides some very profound lessons for the government in Rwanda, which also took over a nation shattered by genocide.

At the end of the Second World War, Germany was divided into four zones each administered by the Soviet Union, Great Britain, France and the United States. The occupying forces had the objective of purging Germany of the poison of Nazi hate propaganda as part of the program to set the nation on a democratic path. The idea was to have Germany "denazified, demilitarized and democratized” (Fullbrook, 1990, p. 205).

But disagreements over currency reform divided the Allies into two camps - the Soviets on the one hand and the Western Allies on the other. The Cold War had begun, starting where the $20^{\text {th }}$ century's most brutal war ended, splitting occupied Germany in two: the Federal Republic of Germany to the west and the German Democratic Republic to the east. Even before the split, the Western occupiers had started building institutions, including the media, as part of the plan to bring liberal democracy to territories they controlled. "What was envisaged was a press responsible to its democratic task, and not to the ideas of profit or propaganda" (Sandford, 1976, p. 19).

Here as well, the Soviets and the Western Allies adopted different strategies. Even among the Western Allies there was no agreement on how to achieve the objective of purging the media 
of Nazi elements and their vitriol. One thing was clear, however: each of the occupying forces adopted for its zone the media structures and practices prevalent in their respective countries:

The Western Allies and the Germans whom they chose to make responsible for the resurrection of the post-war media system, took special pains to ensure the installation of a strong press and broadcasting system designed to withstand every attempt at state subordination and domination by unhealthy concentrations of media power. In very different ways, each sub-sector, policy makers - both Allies and native German - conscientiously sought to ensure pluralism in the press and the broadcasting system (Humphreys, 1994, p. 4).

It all had to start on a clean slate, what Germans often refer to as "stunde null," (hour zero) the concept of the "break with the past" (Humphreys, 1994, p. 3). It was, therefore, "on this tabula rasa [that] the contemporary German press was built, unique in its almost [complete] severance from the past," according to Sandford. "The development of the new West German press took place in two stages. The first was the period of the "licensed press," introduced and controlled by the occupying powers; the second period, the period of the Federal Republic, began when licensing restrictions were removed in the summer of 1949”' (Sandford, 1976, p. 18).

It must be noted that "to achieve the main goal of 're-educating' the Germans toward 'democracy,' the methods adopted by the Western Allies and the Soviets differed according to their very different respective interpretations of the causes of fascism and of the concept of democracy itself' (Humphreys, 1994, pp. 25-26). This is where the Allies and the Soviets diverged. In the Soviet zone, there were blatant attempts to put impediments in the way of social democratic newspapers and those considered too "bourgeois" by denying them newsprint while those aligned with the Communists "received generous financial and material support...'the situation had quite simply been a one-sidedly manipulated press censorship"' (Humphreys, 1994, p. 26). On the other hand, the Western Allies: 
Supported the decentralist idea that the press, like the political parties, had to be rebuilt from the local and regional level upwards. In this manner, the Germans were re-educated gradually into the habits of a decentralised pluralist democracy, which was to be characterized by the widest possible dispersion of political and socio-economic power (Humphreys, 1994, p. 27).

The Allies also chose to lead by example, with each of the occupying administrations setting up a model newspaper for its territory. One of the important first lessons the Western Allies wanted to impart to the Germans was the strict separation of news from comment. The Neue Zeitung newspaper established by the Americans in Munich, for example, "achieved its main purpose of furnishing the new German press with a worthy model of Anglo-Saxon style democratic reporting," Humphreys points out. "In addition, the paper undoubtedly served to bring home to many Germans the then official line of their "collective responsibility" for the Third Reich, but at the same time it was by no means uncritical of the occupation authorities" (Humphreys, 1994, p. 29). With this, the template was essentially laid for those to whom licenses were later issued. The licensing regime, however, had certain stringent conditions attached to it:

In order to ensure a complete break with the Nazi past, it was stipulated that no newspaper would be allowed to use a title that had existed previously in its area, nor would a license be issued to any journalist who had written legally in Germany during the Third Reich, irrespective of his political opinions. Applicants for licenses to publish papers or magazines were subject to extremely strict and thorough screening, and in the American zone were immediately excluded should even the mildest involvement with the Nazis have come to light. The British, and especially the French, applied less demanding requirements, whilst nonetheless refusing to countenance any form of active complicity with Nazism. In a country newly freed from totalitarian dictatorship that had managed in one way or another to mobilize virtually all its subjects it was not surprising that few could meet the Allies' requirements. But still the licensees were found (Sandford, 1976, p. 19).

There were also varied levels of editorial control exercised by the Allied Forces, but these were progressively removed after a very short period. “As early as September 1945, the Americans gave up pre-publication censorship in their zone and shortly afterwards, the British and the French 
followed," according to Humphreys. "Nevertheless, a strict control in the form of postpublication censorship continued" (Humphreys, 1994, p. 32).

For a while, most Germans accepted these restrictions as a "necessary evil" (Humphreys, 1994, p. 37). But as would be expected, they soon started voicing their misgivings. In 1948, six prominent German citizens, including Konrad Adenauer, who would later become chancellor, issued a memorandum criticizing the licensing regime, demanding its end. A year later, their demands were met with the abolition of licensing and the passage of the federal constitution which guaranteed press freedom. Shortly afterwards, the broadcast media started emerging.

Even though the nascent broadcast industry didn't follow the same growth trajectory as the print media, the underlying principle of a pluralist, democratic system undergirded the development of radio and TV in Germany. Humphreys suggests that:

In one very important respect, the British model of public service broadcasting was the main influence on the new German broadcasting system. The new broadcasting organizations were neither to be privately owned, as was overwhelmingly the case in the United States, nor state owned and controlled as in France. Instead, according to the aims of all the Western occupiers, broadcasting organizations to be duly handed back to the Germans were to be 'public-service' bodies. Neither state- nor privately owned, they were to be 'corporations under public law' (Humphreys, 1994, p. 129).

Over time, however, private entrepreneurs were issued frequencies to operate broadcast organizations. These frequencies were issued with the authorities mindful of the principle of plurality and the need to insulate the media against state capture and control. This is what informed the creation of the so-called "broadcasting councils," which Humphreys describes as "an important element of the new broadcasting structure... to give the public representation within the new broadcasting corporations and to provide an instrument for assuring public accountability and control” (Humphreys, 1994, p. 130). 
These ideals were buttressed by the guarantee of press freedom in the German

constitution. There were several other legal instruments against hate speech, which proved to be very crucial pillars in helping strike a remarkable balance between media plurality and the protection of minorities - an essential condition for a thriving, durable democracy. Article 5 of the German Basic Law (Constitution) stipulates that:

Everyone shall have the right to freely express and disseminate his opinion by speech, writing and pictures and freely to inform himself from generally accessible sources. Freedom of the press and freedom of reporting by means of broadcast and films are guaranteed. There shall be no censorship (Federal Republic of Germany, 1949, p. 16).

The Federal Constitutional Court of Germany has over the years used this provision as a basis for evaluating which forms of expression should be categorized as "hate speech" and, therefore, prohibited and which expressions are permitted:

In Germany, hate speech is considered to be an "opinion" in the constitutional sense. It does not matter if the utterance is valuable or worthless. Even aggressive, repulsive value judgments regarding third parties, indeed even statements implying their complete worthlessness, fall under Art. 5 (1) [of the Basic Law]. Of course, such value judgments may be painful to persons or groups at whom they are directed, and these people may feel their dignity and right to be respected and treated equally being violated. Nevertheless, the argument that words in question are "words that wound" is strong enough to deprive hate speech of the constitutional protection of Art. 5 (1) BL. The Federal Constitutional Court has held that opinionated speech loses the protection of Art. 5 (1) BL only in instances when the speaker's "conduct" overpowers his "speech" and coercion replaces or trumps "persuasion" (Brugger, 2003, p. 12).

Article 5 of the German Basic Law has also been used to evaluate when speech can be punished under the criminal offence of holocaust denial. "The prohibited utterance that there was no persecution of the Jews during the Third Reich, is a factual assertion that has been proven untrue according to innumerable eyewitness accounts and documents, to court findings in numerous criminal cases, and to historians' conclusions," according to the Federal Constitutional Court. 
"Taken on its own, therefore, a statement having this content does not enjoy the protection of freedom of expression" (quoted in Brugger, 2003, p. 13).

As Brugger also points out, however, the court's verdict could be different when "the denial of the holocaust is connected to normative value judgments (for example, the claim that the assertion of genocide against the Jews is being used for political purposes to blackmail Germany)" - (Brugger, 2003, p. 13). On this, the court has ruled that Article 5 (1) will protect the speech because "utterances concerning guilt or responsibility for historical events are always complex evaluations that cannot be reduced to factual assertions, whereas denial of an event itself normally will have the character of a factual assertion" (quoted in Brugger, 2003, p. 13).

On the whole, therefore, Germany has used the holocaust and events preceding it to fashion a regulatory regime that jealously protects and defends free speech while valiantly guarding against the tendency of free speech to degenerate into hate propaganda and murderous outrage. Rwanda, on the other hand, has for nearly two decades used the genocide of 1994 as an excuse to beat the media into total submission, forcing many journalists and civil society activists into toeing the government's line. The situation in Rwanda can be likened to conditions under the Nazi regime where Adolf Hitler's aim was "not to encourage reflection or deliberation about alternatives" (Luckert and Bachrach, 2009, p. 32, emphasis added).

In essence, therefore, while Germany learned from the holocaust that the media must be set free from state capture and control, Rwanda has learnt the opposite lesson - shackle the media and constrain the public sphere to stifle reflection or deliberation. What happens in Rwanda in practise is that a self-serving government uses the law to create conditions that facilitate its own propaganda while portraying itself as a democratic regime to earn international legitimacy and financial support, according to Reyntjens (2011). The current situation in Rwanda is also not that 
much different from how the state co-opted the media in Rwanda before the genocide.

Essentially, in Rwanda today, the regime would like journalists to act as its "servants," as was the case in Germany under Hitler (see Humphreys, 1994, p. 22).

In an interview in 1996, Kagame "vowed never to allow free and independent radio in Rwanda” (Kalyango, 2011, p. 15). That was just two years after the genocide and Kagame has done everything in his power to fulfil that vow. Contrast this with the thinking of the Allies who just two years after the holocaust went about issuing licenses for liberal, pluralist newspapers and preparing the ground for public broadcasting in Germany. Thus nearly 20 years after the genocide, there are no independent daily newspapers in Rwanda and its supposedly independent private radio stations are playing it safe by avoiding controversial issues (see Frère, 2009). It is only recently that the government issued a permit for a private TV channel which intends to only "focus on business, entertainment/culture, sports and news" (Gasore, 2013, March 02). Through it all, the regime maintains a tight grip on the public broadcaster.

When Rwanda's post-genocide transition was coming to an end, much of the restrictions on the media and the public sphere were "justified by the fragile security situation that Rwanda has experienced since 1994, during which it [had] been in a state of almost permanent war with the Hutu heirs of the Habyarimana regime on the DRC territory" (International Crisis Group, 2003). Kinzer also notes that:

Kagame and his allies argue that opening too much political space in Rwanda now would unleash ethnic hatreds and possibly lead to another genocide. His critics, including [Nyamawasa and his co-authors of the 'Rwanda briefing], argue the opposite: that opening political space is the best way to prevent another genocide. Both arguments are plausible, and both should be openly discussed (Kinzer, 2011, January 27). 
Not even the recent amendments to Rwanda's media laws make any such discussion possible, however. The regime would not even brook the idea of an open discussion, leaving the NGO, Article 19, to come to the conclusion that:

Incomplete legal reform is particularly disappointing given the overall press freedom situation in the country, characterized by the existence of too many laws which are not in line with international standards on freedom of expression, and by the imprisonment of journalists on charges of libel, "genocide ideology", undermining state security or giving false testimony (Article 19, 2013, March 18).

What this basically means is that the Rwandan administration ought to go back to the drawing board and at the very outset state its fundamental principles and grand vision for the future of the country. Rwanda's constitution demands of its political leaders to make sure the nation is run democratically, but the government's treatment of journalists and its apparent closure of the political space makes it difficult for anyone to believe that the current regime is committed to democratic ideals and that the constitution is just so much window dressing. Even though the media is not necessarily the foundation for democracy, a strong, vibrant, independent media can help sustain democracy and make it durable: "Where there is democracy or where there are forces prepared to bring it about journalism can provide a number of services to help establish or sustain representative government" (Schudson, 2008, p. 12). This, it seems, was what the victorious Allies had in mind when they started implementing their plan for ushering Germany into a new era of liberal democracy.

The question to ask at the outset is what type of democracy has Rwanda been building since the end of the genocide and what sort of democracy is in the best interest of Rwanda and its people. In answering this question, it is important to bear in mind that the genocide of 1994 occurred at a period when the country was supposedly going through democratic reform, with multiple political parties and print media outlets. But it is clear that both the regime before the 
genocide and the one which took over after the calamity, opted for what Zakaria describes as an “illiberal democracy:"

Illiberal democracy is a growth industry...Far from being a temporary or transitional stage, it appears that many countries are settling into a form of government that mixes a substantial degree of democracy with a substantial degree of illiberalism. Just as nations across the world have become comfortable with many variations of capitalism, they would well adopt and sustain varied forms of democracy. Western liberal democracy might prove to be not the final destination on the democratic road, but just one of many possible exits (Zakaria, 1997, p. 24).

Against this background, however, Chege insists that liberal democracy can and should be made to work in Africa. "Africa now harbors a large number of rudderless regimes drifting between success and catastrophe, with pretension to electoral legitimacy but no real popular backing to speak of," he says and warns that "if badly handled, these vessels could capsize, as experience has already made clear" (Chege, 1995, p. 47).

Liberal democracy, then, is the governance imperative for Rwanda (as it was for Germany after the Second World War) and in that context the role of the media cannot be overemphasised. As Humphreys points out, "the mass media system is a very useful mirror in which to examine the level of democratic progress" (Humphreys, 1994, p. 2) in any country.

For a nation scarred by a genocide in which the media has been severely implicated, the overarching principle should be for a democratic and liberal media that is not beholden to any particular interest, be they in government or in the private sector. Here, the lesson from Germany is simple: more media in different hands is better than fewer outlets in the hands of a very small segment of the population. The situation becomes even more dangerous when the few available media outlets are controlled by or aligned with the same group of people who wield the coercive powers of the state. It was this state of affairs that made it possible for Hitler to use the media to create "a frightened public conformity on the part of many Germans" (Fulbrook, 1990, p. 181, 
emphasis added). It was the same frightened public conformity that pushed Rwandan Hutu to kill their Tutsi neighbours in 1994 - under coercion from the army and militia groups.

In Rwanda today, with journalists, politicians, activists and many others fleeing into exile, it is possible to suggest that a good number of those who toe the government line are doing so under the same pall of "a frightened public conformity." To prevent history from repeating itself, therefore, one of the strategies for reducing (if not eliminating) both the fright and the conformity would be to create conditions where the population is able to lawfully express itself without fear of extra-judicial retribution.

Twenty years after the genocide is long enough for the government of Rwanda to stop treating its citizens like babies (see International Crisis Group, 2002; Reyntjens, 2004) and start trusting in their capacity for good. The wounds from 1994 may not have healed completely and ethnic animosity may not be completely eradicated, but a paternalistic approach to governance that frightens even Tutsi genocide survivors into flight might itself lead to further conflict. After 20 years of censorship, harassment and intimidation, perhaps the time has come for the government to make serious overtures to assure the media that whether they back the government ideologically or not, they would be given the freedom to work like journalist do in democratic nations around the world, the only major prohibitions being a ban on genocide denial and the propagation of hatred (discussed below). There could also be other reasonable and justifiable limitations on free speech, applied proportionately to defend reputation and also in the interest of national security and public morality.

The first of the government's overtures to engender media freedom could be the complete abolition of newspaper licensing. It ceased in Germany within four years of the end of the holocaust. Rwanda has no excuse issuing newspaper licenses two decades after the genocide - 
other than using it as a tool to beat newspaper publishers and their journalists into submission. Newspaper licensing was previously a function of the Media High Council. With the new Media Law passed in 2013, however, this function would be taken over by a "media self-regulatory body," which would not only issue newspaper licenses but would also be responsible for granting accreditation for journalists to work in Rwanda. As the NGO, Article 19, points out, "international standards are clear that there is no need for general accreditation, as this is an unjustified restriction of freedom of expression" (Article 19, 2013, March 18).

The greater danger, though, lies in the fact that the Rwandan government is rather notorious for infiltrating seemingly independent bodies with its trusted hands and minds, who would only do exactly as the government wants of them (see Reyntjens, 2010; Nyamwasa et al, 2010; Longman, 2011). This gives a semblance of democratic legality and legitimacy to what effectively are decisions taken by what Nyamwasa et al describe as Rwanda's “informal government," the inner core of the regime that Reyntjens also refers to as "the new Akazu".

In sum, the licensing of newspapers and the accreditation of journalists is the first tool the government uses to either co-opt or intimidate the press. Whether such licenses or accreditation is being granted by an office attached to that of the president or a "self-regulatory body" is irrelevant. It is still wrong and Rwanda is better off without it. Continued newspaper licensing will only ossify a legal regime which is completely at variance with basic international standards. The longer it persists the higher the probability that future generations of Rwandans would see it as an institution that needs to be preserved rather than abolished.

The licensing regime for broadcast media is, on the other hand, perfectly within international practice. All around the world, broadcast networks are required to obtain licenses before they go on air. This is partly because the broadcast spectrum is a limited resource that 
needs to be allocated judiciously. The problem in Rwanda, however, has been the fact that the broadcast regulator was for so long attached to the office of the president and seemed to lack the independence necessary to impartially decide, on well-determined and open criteria, who deserves to be granted a broadcast license. The result has been that licenses are only granted to broadcast operators who appear to agree to operate within the safe territories of business, entertainment and sport.

As Carver points out in relation to most African countries and not just Rwanda in particular, this is cause for concern. "Procedures for allocating private broadcasting licenses are almost invariably not transparent and the range of candidates is often limited to those with personal links to government," he says. "Hence the emergence of private radio has seldom resulted in genuine pluralism" (Carver, 2000, p. 195). It was the absence of such plurality that made it possible for RTLM to dominate the Rwanda airwaves with its extremist, governmentsanctioned hate propaganda. The absence of plurality is as dangerous today as it was in 1994 .

Even though the current government has not shown any signs of peddling hatred, the fact that its messages are the only unchallenged versions of events and issues on the Rwandan airwaves means that Rwandans are not talking with each other as they should. The government is rather talking at them, a perfect condition for the creation of the "frightened public conformity" that does not auger well for long-term, sustainable nation-building (Fullbrook, 1990, p. 181, emphasis added). One of the best ways to deal with this problem is to issue more licenses to broadcast organizations willing and able to venture into news and political programming.

As an independent regulatory agency issues licenses, the government would be best advised to cede control of the public broadcast system to an independent institution which would be responsible for appointing lead personnel for the broadcaster while administering its budget. 
Recent legislation transformed the former Office Rwandais d'Information (ORINFOR) into the Rwanda Broadcast Agency, the country's public broadcast organization. It remains to be seen whether this agency would be any more independent than the one it replaced, especially considering a government official's assertion in previous years that "public radio and television are there for relaying the action of the government" (quoted in Waldorf, 2007, p. 411). As Carver points out, this is not a problem in Rwanda alone, but in most other African nations where state broadcasters are "shameless propagandists" for the ruling elite (Carver, 2000, p. 193). For a country that badly needs to ward off such propaganda, Germany offers a very good model. Here, the German idea of the "socially-significant groups," (such as the associations of lawyers, doctors, teachers, engineers, religious groups and artisans) could be used to create an independent body to supervise the operations of the public broadcaster and defend it from government intrusion or interference (see Humphreys, 1994, p. 57). One would also suggest that a special fund be set up specifically for the public broadcaster, with funds generated from mobile phone levies, for example.

All of these measures would ensure that the government can neither control the personnel of the public broadcaster nor unilaterally decide to cut funding if the agency refuses to do its bidding. The idea is to make sure that public broadcast agency is as independent as possible and is not tied to the apron strings of the government. Measures like these would make it difficult (if not impossible) for the regime to interfere in its operations or intimidate its editorial personnel.

For the private sector, there could be a requirement that every application for licensing should include a list of about ten representatives from the socially significant groups, constituting each station's broadcast council. This would be the body to "ensure a balance and diversity of opinion and safeguard against abuse of power by individual groups" (Humphreys, 1994, p. 142). 
Since radio is the most popular medium in Rwanda, ensuring its freedom and guarding against potential excesses would help it take the lead in opening up debates on the many issues that have been papered over for many years in Rwanda. As Nyamwasa et al suggest:

Rwanda cannot move beyond the current quagmire without a comprehensive debate on the many issues that drive conflict in the country. Some of the issues that such a dialogue would address (issues on which the RPF does not yet see eyeto-eye with its opponents and critics today) include Rwanda's history, the issue of ethnicity, the nature and causes of the conflicts Rwandan society has gone through, the state of political governance in Rwanda today, democratization and apportionment of power and control of state institutions (especially the military and security services) in a newly democratic Rwanda, strategies for promoting reconciliation and peace-building, protection of the minority from marginalization, mechanisms to prevent the 'tyranny of majorities,' exclusion or atrocity in any post-transition political system and Rwanda's relations with its neighbors (Nyamwasa et al, 2010).

Much of this necessary debate would be controversial and contentious, but it would ultimately be productive and useful. In having this debate, it is imperative for the state to put very strong safeguards in place to check and punish hate speech. The suggestion, therefore, is for the current laws on genocide denial and genocide ideology to be reviewed, their scope reduced to make them less of a threat to journalists, activists as well as politicians and blunt their use as a tool for suppressing dissent.

Article 34 of the Rwandan Constitution is supposed to guarantee free speech, with provisions that sound almost like Article 5 of the German Basic Law. The Rwandan stipulation is that:

Freedom of speech and freedom of information is recognized and guaranteed by the state. Freedom of speech and freedom of information shall not prejudice public order and good morals, the right of every citizen to honor, good reputation and the privacy of personal and family life. It is also guaranteed so long as it does not prejudice the protection of the youth and minors. The conditions for exercising such freedoms are determined by law (Republic of Rwanda, 2003, p. 9). 
The problems, however, arise when this provision is coupled with other laws, especially the legislation against genocide ideology, to frustrate free expression. As a crime, genocide ideology is defined as:

An aggregate of thoughts characterized by conduct, speeches, documents or other acts aiming at exterminating or inciting others to exterminate people basing (sic) on ethnic group, origin, nationality, region, color, physical appearance, sex, language, religion or political opinion, committed in normal periods or during war (quoted in Amnesty International, 2010, p. 13).

As Allen and Norris point out, "Rwanda's genocide ideology law is too vague and overbroad and the government has been criticized for using it against people with dissenting views" (Allen and Norris, 2011, p. 168). This law was used to prosecute a radio presenter who appeared to have unintentionally mixed up the Kinyarwanda words for "victims" and "survivors" in a newscast (Noorlander, 2013, March 20). According to Allen and Norris, "the law while protecting against potential incendiary speech, is too vague and open to abuse to adequately protect legitimate expression and valid differences of opinion" (Allen and Norris, 2011, p. 169). Other legal analysts and human rights NGOs have expressed similar concerns. Amnesty International, for example, points out that "the law constitutes an impermissible restriction on freedom of expression under international law," adding that:

The extremely broad scope of conduct and speech that is, or may be prohibited under this law, all of which are punishable by long terms of imprisonment fail to meet the international requirement of proportionality, as they go well beyond that which is necessary to prevent hate speech or meet any other legitimate interest (Amnesty International, 2010, p. 14).

Amnesty International then joins the likes of Noorlander and Waldorf to call for an urgent revision of this legislation "so that genuine incidents of hate speech are differentiated from legitimate freedom of expression" (Amnesty International, 2010, p. 18). Furthermore, as the NGO, Article 19 points out there is need to review the laws which criminalize libel and 
defamation (see Article 19, 2013, March 18). Government has no business playing a prominent role in the defense of individual reputations. Anyone who feels defamed or libelled should initiate legal proceedings on their own without any government intervention whatsoever. As it stands now, criminal libel makes it all too easy for the government to clampdown on journalists who have not even offended the government in any significant way. The law also makes it easy for those close to the corridors of power to use the coercive apparatus of the state to intimidate and harass journalists.

One cannot, however, just ask the Rwandan government to review its media laws without touching on the imperative of media accountability. The recent legislative reforms introducing a media self-regulatory body, appear to be better than the previous situation under which an agency attached to the office of the president was responsible for regulating the media. But if history is anything to go by, there is every reason to suspect that this so-called self-regulatory body would be as ineffective as the agency it is replacing. Higiro points out that a similar initiative by the Habyarimana regime in the early 1990s turned out to be a ruse to "influence the content of newspapers" (Higiro, 2007, p. 83). As pointed out earlier, the Rwandan regime’s penchant for infiltrating such supposedly independent organizations has been well-noted and frequently condemned (see Reynjtens, 2010; Nyamwasa et al, 2010 and Longman, 2011).

Having co-opted so many of Rwanda's journalists to its side, it is hard to see how this selfregulatory body named the Rwanda Media Commission, would work independently of the regime. "This is the fear," Tom Rhodes of the Committee to Protect Journalists says, "that the selfregulatory body will eventually be over washed with pro-government individuals" (personal communication, January, 2014). 
Even if one were to assume that such a verdict is premature, considering that the selfregulatory body has not even started work yet, there is ample evidence from around the world that self-regulation hardly works in the public interest. The new laws only move Rwanda from the extreme of a meddlesome, politically influenced regulator to another extreme of an agency with self-interested personnel drawn from the industry under regulation. Neither is a viable option. As the recent debate in the United Kingdom has revealed, following the Leveson inquiry, selfregulation presents its own problems. In the U.K., the self-regulator for many years, the Press Complaints Commission (PCC) failed to deliver on its stated mandate, leading the Leveson inquiry to urge its replacement. "Some argue that self-regulation is a flawed concept in an era when there are specialized statutory regulators covering almost every other profession, from medicine to the law" (Sabbagh, 2012, November 28). In the report on his inquiry into the practices and ethics of the press, Lord Justice Leveson summed up one of the major failings of PCC:

In reality, its powers are inadequate, especially regarding the right to conduct effective investigation: The PCC is at the mercy of what it is told by those against whom complaint was made. In practice, the PCC has proved itself to be aligned with the interests of the press, effectively championing its interests... When it did investigate major issues it sought to head off or minimise criticism of the press... Its attempts to investigate phone hacking allegations, which provided support for the News of the World, lacked any credibility: save for inviting answers to questions, no serious investigation was undertaken at all (Leveson, 2012, p. 12).

At a news conference to launch his report, Lord Justice Leveson insisted that self-regulation without a "legislative backstop" simply amounted to "the industry marking its own homework" (quoted in Sabbagh and O'Carrol, 2012, November 29). Thus Cathcart points out that "newspapers that hold others to account should themselves be accountable in a way that conforms to modern public expectations.” 
One of such expectations is for the regulator to be seen to be working more in the interest of the public and less in the interest of the industry under regulation, if at all. Under current circumstances it is very difficult to see self-regulation working in Rwanda. What the country needs is a truly independent media authority, composed, following the German example, of representatives of "socially significant groups" (Humphreys, 1994, p. 57), including, among others, political parties, religious groupings, professional organizations and labour unions. Members of these groups will choose their representatives to this body.

For this to be achieved, the government would be best advised to stop the practise of infiltrating civil society groupings and make sure that membership of the Rwanda Media Commission decidedly includes organizations and individuals that are deemed to be among its most ardent critics. Thus the government would not appoint its favourites to do its bidding on the Rwanda Media Commission. The commission would then be independent enough to monitor media standards and to receive and adjudicate on complaints from members of the public who may feel that sections of the media are engaged in unprofessional or unethical conduct. In this way, the commission also serves as an alternative dispute resolution mechanism. Journalists and media organizations that fail to abide by its rulings can then be referred to the courts for appropriate sanctions. This could engender accountability among journalists and the media without any government involvement, saving the regime from the added responsibility of keeping the media in line and coming across as repressive.

Here, there is even an African example that Rwanda can learn from - the National Media Commission (NMC) of Ghana, which investigates complaints from both the public and government about shoddy journalistic work. Much of the commission's work is aimed at resolving disputes "in an amicable manner, devoid of the acrimony that characterizes court proceedings and 
the perceptions of bias that surround the operations of commissions that are seen as extension of the government:"

The NMC, for example, operates on the principle of goodwill and moral suasion in getting parties to comply with consensual decisions that it arrives at in the process of holding the media accountable. Unfortunately, this is not always successful. Some journalists have refused to appear before it, while others have ignored its directives. In spite of these limitations, it must be recognized that whereas these non-adversarial bodies may not have coercive power, the impact of their rulings on the reputation of journalists and media organizations can be significant enough to elicit the kind of moral suasion needed to keep media practitioners responsible and answerable (Tettey, 2006, p. 238).

Ghana's Media Commission may not be as strong as it could be, but Rwanda can learn from the model of its independence and, possibly, go a step further to give its version of such a commission the power to enforce its rulings. Here, once again, the biggest concern would arise from the possibility that the government would try (or even coerce) the election of its favorites to this body. However, if the law allows for a large commission of at least 30 members elected from the socially significant groups, the possibility of government infiltration could be reduced.

Above all else, what Rwanda needs most is a strong and independent judiciary to interpret its laws and apply them in such a manner that the regime is so legally restrained that it cannot resort to extrajudicial measures. That is what the German Federal Constitutional Court did for so long to help entrench a culture of openness and respect for free speech while ensuring that hate speech against minority groups was reduced to the barest minimum.

The German system that has been held up here as an example for Rwanda is by no means perfect. No human institution is. In Germany currently there are serious concerns over the dangers of concentration as media organizations continue to merge to take advantage of economies of scale (see Humphreys 1994). But the fact that Germany and Rwanda share similar 
histories of governments using the mass media to propagate hatred underlines the need for the latter to learn from how the former recovered from and dealt with the poison of hate propaganda:

Germany provides a successful example of the type of government Rwanda professes to be building, a democracy that has successfully balanced rights of speech and association with the need for political stability. As such, it offers lessons that will assist the international community's support of that development. Specifically, the German experience suggests that Rwanda would benefit from clarifying and amending its laws, and most importantly, continuing to develop judicial independence and procedural safeguards (Pall, 2010, p. 10).

Furthermore, Rwanda can also learn from Germany that economic growth does not need to be achieved at the expense of liberty. From the ruins of the Second World War, Germany laid a liberal democratic foundation for an economy that is touted today as a "miracle" (see Lewis, 2001, p. 119). This shows that economic development and the enjoyment of civil liberties (including free speech) are not mutually exclusive. That, more than anything else, is the one most important lesson Rwanda can learn from Germany - that the economy can best grow (and sustainably so) in an atmosphere of openness and democratic liberty.

The current Rwandan regime, it might appear, may never be inclined to put any of the best lessons from Germany and elsewhere into practice without some international pressure from bilateral and multilateral donors. These donors could insist that their taxpayers cannot continue to support an authoritarian regime, if for nothing at all, out of concern that an autocratic regime, which suppresses dissent, is more likely to instigate another violent.

In the final analysis, the one major historical difference between post-holocaust Germany and post-genocide Rwanda is that the reconstruction of the former was supervised by foreigners while the latter was entirely left to natives. In other words, while western Allies pumped money into the Federal Republic of Germany, they also lived in the country to oversee the process of reconstruction, making sure that a durable system had been built before they handed it over to 
native Germans. One could say there was no other way because the Allies conquered Germany and had a responsibility to stick around to turn it around. But, essentially, that was how Germany, with international money and supervision, was transformed from a belligerent pariah state that sparked two world wars into one of the world's most democratic nations with a strong economy to boot.

The same cannot be said of Rwanda. When the Rwandan Patriotic Front ended the genocide, the situation was that of a rebel army taking over a broken nation, with an economy in tatters. Unlike the Germans, Rwandans were left to do much of the work themselves, with the international community offering a lot of money and, in some cases, technical assistance. Rwanda therefore gets a lot of international money with very little of the necessary international supervision. But a good mix of the two is required to deal with any extremist tendencies that could plunge Rwanda into the dark abyss of violent conflict. The role of the international community in pushing for greater freedom (especially freedom of speech and of the press in Rwanda) therefore needs to be seriously considered. 


\section{Chapter 7}

\section{CHALLENGE AND SUPPORT}

Paul Kagame likes to dream big. One of his larger dreams is to make his tiny nation of 11 million people "Africa's Singapore." The vision revolves around a plan to place Rwanda at the centre of the information communication technology revolution in Africa. As The Economist reports, Kagame is "nothing if not ambitious." That is not to say that he cannot achieve what he's set his mind to. It just so happens to be easier said than done:

Rwanda is best known for the genocide that claimed at least 500,000 lives in 1994. It has been peaceful since then, but lacks nearly all of Singapore's advantages. Singapore has the world's busiest port; Rwanda is landlocked. Singapore has one of the world's best-educated populations; Rwanda's middle class was butchered in 1994. Singapore is a gateway to China; Rwanda's neighbors are "less than ideal," as a recent report from the Legatum Institute, a British think-tank, put it. Uganda is corrupt; Burundi a basket-case; Congo worse (The Economist, 2012, Feb. 25).

Despite all these challenges, The Economist is quick to point out that Rwanda has one major advantage: "the rule of law." The magazine also stress that "the country is blessedly free of red tape" and "ranks 45th in the World Bank's index of the ease of doing business, above any African nation bar South Africa and Mauritius" (ibid.). For a country that suffered one of the bloodiest mass atrocities of the $20^{\text {th }}$ century, there is a lot to say about what Rwanda has achieved 20 years after the genocide. A lot of the credit is often given to Paul Kagame, described by The Economist as:

A tough-as-Kevlar bush fighter [who] stopped the genocide and chased the militias who carried it out into neighboring Congo. His forces killed huge numbers of people. His enemies are terrified of him. The elections he holds are a sham. On the plus side, he has overseen dramatic improvements of Rwanda's institutions. He understands that his country may collapse again if it does not grow richer, and he is determined to make it easier for businesses to operate (The Economist, 2012, Feb. 25).

For all Rwanda has achieved, Kagame has earned himself a lot of powerful friends around the world. Bill Clinton and Tony Blair are just two of his most prominent global admirers. The former 
goes so far as to describe Kagame as "one of the greatest leaders of our time," (quoted in McGreal, 2013, May 19). Kagame gets the red carpet treatment almost everywhere he goes. In international circles, the admiration for him appeared to be boundless. Until recently.

After a United Nations report revealed the extent of Rwanda's involvement in the conflict in the Democratic Republic of Congo, several countries started reviewing their notes on Kagame and his credentials as a global statesman. The United States and Britain cut back on their budgetary support for his country and threatened to do more if Rwanda didn't get it troops out of D.R. Congo. That was the first time in 20 years that the Kagame regime appeared to have been rattled, its confident swagger on the world stage suddenly reduced to diplomatic wobbles and frenzied attempts to assuage the brewing anger of the world community.

That U.N. report detailing how Rwandan troops had been fighting alongside rebel forces in the Congo, bringing untold hardship to millions of people, revealed very little that the world's NGO and human rights community hadn't already exposed. It took not one, but two U.N. reports - in 2002 and 2012 - for the world community to take action against Rwanda (See Gettleman, 2008, December 3; 2013, September 4; and Smith, 2012, October 18). For many years, whenever the question of Rwanda's involvement in the D.R. Congo was raised, Kagame and his henchmen would deny it with sharp diplomatic put downs:

Besides being unable to access the sites where massacres took place, reporters had particular difficulty with the new doctrine of information control Paul Kagame imposed, a doctrine built around denial. In late 1996, the Rwandan authorities denied that [its troops] were fighting alongside the [then Zairean rebel force], ADFL. Later Rwandan officials denied being involved in any atrocities against Rwandan refugees and Zairean civilians. Later still, after Kagame acknowledged the RPA's involvement in Zaire, certain Rwandan officials denied that [Kagame's] words would have implied direct [Rwandan army] engagement (Pottier, 2002, p. $55)$.

The key point here is that the Rwandan regime has developed a certain expertise in the dark art of 
denial. And denial is its main tactic for dismissing criticism of its human rights record at home, including its heavy-handed closure of the Rwandan public sphere and the suppression of free speech.

As was the case with its involvement in the Congo (formerly Zaire), countless reports have been compiled by organizations ranging from the International Crisis Group to Human Rights Watch, Amnesty International and even the African Peer Review Mechanism (APRM), detailing policies and practises that put Rwanda at the risk of a violent implosion in the future. All of these reports have been received with contempt and brushed aside with one of the regime's most effective tools - denial. For example, when an African Union panel published a report, which largely praised the government on a range of issues but criticized it on political governance, Paul Kagame responded that:

[The] people who made the peer review report were experts who studied in the best universities in the world. We gave them access to all the information they wanted, but I was so surprised when they came up with allegations that Rwanda has no political space. Probably, they don't understand the meaning of political space because if they knew, Rwanda would be an example (quoted in Reyntjens, 2010, pp. 6-7).

In similar vein, Reyntjens reports that:

The 2005 US Department of State's Country Reports on Human Rights Practices met with an acerbic rebuttal. The report was said to be "riddled with inaccuracies and inconsistencies," and most of its observations were denied. Thus, "there are no political detainees in Rwanda," the accusation that political freedoms were limited was "a subjective opinion unsupported by evidence" and "government considers the charge that Tutsi, particularly, English-speaking Tutsi, are favoured contemptible and unworthy to be dignified with a reply (Reyntjens, 2010, p. 7).

Faced with such aggressive denials, the international community, even the donor nations that provide the bulk of the funding to keep the Rwandan economy running, has been left to look on as the Kagame regime dominates the public sphere, suppressing dissent and hounding opponents 
into exile. The success of the regime's strategy of denial is based on two major factors - the regime's own economic management (considered to be quite efficient in comparison with other African countries) and the international community's guilt over its failure to intervene to prevent the 1994 genocide.

First, it is hard to deny that that Kagame's record on the economy has been spectacular. Hardly anything gets written about him without mention of how he has doggedly managed to make Rwanda's economy stronger than that of many African countries, including those which have never experienced civil strife. This "performance legitimation," as Longman (2011, p. 41) calls it, makes it difficult for the world community to criticize the human rights record of a regime which doesn't appear to be as wasteful with donor money as many African countries are. "Some observers suggest Rwanda could follow the model of South Korea and Taiwan, in which democracy comes only after solid economic growth" (Longman, 2011, p. 42). Thus many are those in the international community who are not just willing to turn a blind eye to Kagame's excesses but would even go further to argue that they are justified. While acknowledging that Kagame is a despot who could be likened to past African dictators like Iddi Amin, Chapman, for example, suggests that:

Kagame does not seem a man motivated by the selfish desires of previous African leaders. Rather he presents a vision for a future Rwanda, inspired by the Asian Tigers and by the collective pride that is fostered by a flourishing nation. He has proven his strengths and the West has tacitly acknowledged his legitimacy with the levels of aid they have gifted to the Rwandan government directly. Human rights violations are a small price to pay for Rwanda's remarkable progress. Kagame is a dictator. But as long as he maintains stability and delivers reasonably equitable development, he is the sort of dictator Rwanda needs (Chapman, 2011, June 9).

There are others, however, who argue that such blatant support for a dictator simply on the basis of his economic record is not only insulting to the people of Rwanda, but is also a very bad 
precedent for countries recovering from historical trauma. Responding to Chapman's comments above Tertsakian pointed out that:

The impressive speed of Rwanda's reconstruction and economic growth after the genocide should not blind us to the fear and intimidation that Rwandans live with from day to day. Instead of swallowing the propaganda of "economic development first, human rights later," we should put ourselves in the shoes of Rwandans today: would we be prepared to sacrifice our right to free speech or political participation for the sake of "reasonably equitable development" or subjective "political stability?" The Rwandan government should have the confidence to offer its citizens not only economic development but also the space and the security to speak and challenge without fear. Clean streets and the absence of plastic bags will be of little comfort to those who remain behind bars for expressing their opinions. To describe Kagame as "the sort of dictator Rwanda needs" is an insult to Rwandans who have lost their lives or their freedom under his rule (Tertsakian, 2011, June 15).

As the debate rages over whether or not economic progress should prevent the international community from calling the Rwandan regime to order for stifling free speech and violating other basic human rights, Kagame and his government use the "genocide credit" (see (Reyntjens, 2010, p. 27) to question the moral authority of any international player who voices any criticism. This has established a certain willingness by the international community to tolerate the regime's excesses to make up for its failure to help prevent the genocide in 1994. The government in Kigali, Reyntjens argues, has not only fostered this genocide credit but has also forcefully and ingeniously managed to foist on the conscience of the international community:

The combination of [the Kagame regime] having defeated the forces of genocide, its efficient and cynical exploitation of international feelings of guilt and ineptitude, and its regional military might allowed it to tackle unsympathetic voices aggressively and with arrogance. Strongly worded, indeed intimidating statements reduced to silence many of those who might otherwise have spoken out. This assertive and proactive behaviour has allowed the regime to escape judicial scrutiny both at the ICTR and the justice system of third countries. Though coming from a small and very poor and aid-dependent country, it has also served to avoid condemnation of the regime's human rights record, its poor democratic credentials, its dangerously flawed political governance and its aggressive behaviour in the region. The major instrument for achieving this tolerance has 
been the skillful and cynical use of the genocide credit, which allowed the regime to both capitalize on the guilt feelings of the international community and to present itself as the victim of the genocide (Reyntjens, 2010, pp. 33-33).

Thus for two decades a repressive regime has been given a carte blanche not just to do what it likes domestically, but also to ride roughshod over the international community that provides much of the money it needs to pursue its economic and developmental goals. The international community has become an active supporter of a regime whose most avid praise singers acknowledge is a dictatorship. "Rwanda isn't an easy one," an unnamed "Western official” told the New York Times journalist, Jeffrey Gettleman. "Is Kagame repressive? Yes, definitely. Have we talked to him about this, about opening up? All the time. I don't know how fragile things are. So we give him the benefit of the doubt" (quoted in Gettleman, 2013, September 4).

From all that has been written about Rwanda over the past 20 years, however, it is not very difficult for one to come to the conclusion that the situation in Rwanda is very fragile and that one of the best ways for preventing the country from sliding into crisis once again is to simply stop giving Kagame the benefit of the doubt. This would mean that support for Rwanda should now come with more strings attached to challenge the government to do more to expand the space for the enjoyment of basic human rights and freedoms in the country, starting with the freedom of speech and of the press. This is because "freedom of expression is essential to and interrelated with the realization and exercise of all human rights" (Amnesty International, 2010, p. 9).

The first place to start could be a return to the drawing board to carefully review Rwanda's transition after the genocide. This would reveal that Rwanda is standing on very shaky foundations that could crumble anytime:

For the time being, Rwanda is relatively peaceful, but how long the suppression of 
democracy can remain sustainable is unclear. Much like African states from the first decades after independence, Rwanda is effectively a one-party state with a corporatist civil society and a leader elected by plebiscite. The strategy of performance legitimation assumes that prosperity will earn public support, but in Rwanda the lack of democracy is contributing to unequal development, in which wealth is concentrated disproportionately in the hands of a small group, primarily Anglophone [Tutsi] returnees from Uganda (Longman, 2011, p. 42).

Turning this situation around, leading to the building of a stronger, inclusive democracy for Rwanda, would involve the international community drawing up certain liberal democratic benchmarks for the country in return for much-needed budgetary support. A liberal democracy in Rwanda should lead to greater press and speech freedoms, which would in turn promote reconciliation in the country and contribute to the attainment of a durable peace.

The first thing to insist on in this regard is a strict separation of powers. In the short term, emphasis could be placed on building a strong, independent judiciary to interpret and apply the laws passed by what remains a rubber-stamp legislature (see Sebarenzi, 2011). The "lack of an independent and impartial judiciary is probably the greatest constraint to the development of democracy in Rwanda" (Nyamwasa et al 2010). This is a serious indictment on the international community which has pumped millions of dollars into building Rwanda's judicial system. Contrary to what The Economist (2012, Feb. 25), says about the "rule of law" being an advantage for Rwanda's quest to attract investments, Nyamwasa et al insist that:

Instead of being the protector and defender of citizens' fundamental human rights, the judiciary has become one of the main tools by which the government perpetuates authoritarian rule by persecuting opponents and critics. Judicial and law enforcement authorities are used to persecute government critics and opponents through trumped up charges of genocide, revisionism, genocide ideology, corruption and, more recently, immoral conduct (Nyamwasa et al, 2010).

The first step towards securing the fulfilment of the constitutional guarantee of free speech in Rwanda is to stop the country's judiciary from serving as an appendage of the executive. This will 
not happen overnight, but a mechanism that makes it possible for those who claim to have suffered injustice to seek redress (or the very minimum, a hearing) in an internationally mandated court could help ensure judicial independence domestically.

When the journalists Agnès Uwimana and Saïdati Mukakibibi, were convicted of various crimes including genocide ideology and disrespecting the president, they filed an appeal with the African Commission on Human and People’s Rights. "Rwandan courts never gave us justice," Uwimana said. "It was clear that whatever evidence we gave fell on deaf ears," Mukakibibi added after filing the appeal (quoted in Rhodes, 2012, December 11). Even though there has been no word yet from the commission about the case, the fact that the journalists could turn to the commission is an indication that such an international judicial body could be used by the international community to promote greater respect for human rights in Rwanda and, by extension, judicial independence in the country. When domestic judges know that their rulings could be discredited by an international court, they might be less inclined to do the bidding of the regime.

For now, the African Commission on Human and People's Right could be suggested as a final arbiter for cases involving alleged human rights violations in Rwanda. The commission itself might need support from the international community to conduct its investigations and adjudicate cases. What is important here is that the commission's rulings could be persuasive and influence human rights jurisprudence in Rwanda (including free speech). Moreover, the fact that the commission is an African institution with African personnel would blunt the Rwandan regime's tendency to use the genocide credit and accusations of imperialism to silence western critics.

While pushing for judicial independence, the international community could also start making demands for the immediate pardoning and release of journalists and political prisoners, 
whose only crimes had been the expression of views the government considered offensive. A former president, Pasteur Bizumungu received just such a pardon in 2007 after serving two of a 15-year sentence for alleged attempts to incite a rebellion. The demand for the release of journalists and politicians who have been jailed for speech offenses which have nothing to do with hate speech, should be accompanied by an insistence on a review of the laws on "genocide ideology." This, as has been pointed out, is the law largely used in recent years to stifle free expression and to intimidate journalists who fall out of line. The law that requires political parties to obtain prior approval from the Forum of Political Parties before being registered also needs to be repealed or, at the very least, reviewed. This forum (a sort of self-regulatory body for political parties), "has made Rwanda a de facto one-party state” (Longman, 2011, p. 34). A one-party state is hardly a respecter or enabler of fundamental rights and free speech. Only a return to true multiparty democracy, therefore, would pave the way for the expansion of the public sphere and, ultimately press freedom and freedom of speech.

In making this suggestion, one is mindful of that fact that the genocide took place at a time when Rwanda was supposedly transitioning into multi-party democracy. It is also noted that in a country where ethnic animosity persists, there are justifiable fears among the current Tutsi ruling elite that true multi-party democracy could bring the extremist elements within the Hutu majority back to power, leading to an attempt to finish off what was started in 1994. As Reyntjens suggests "the RPF would simply lose power if it accepted a competitive political system" (Reyntjens, 2010, p. 33) in a country whose majority ethnic group is increasingly feeling marginalized by a small clique from the minority ethnic group. And so, as Mamdani points out, Kagame and his inner circle see themselves not only as rulers of Rwanda, but also as protectors of the Tutsi ethnic group: 
Three convictions underline the character of post-genocide power in Rwanda. The first is an overwhelming sense of moral responsibility for the very survival of all remaining Tutsi, globally. The second conviction - also a direct outcome of the experience of genocide - is that Tutsi power is the minimum condition for Tutsi survival (Mamdani, 2001, pp. 270-271).

The push for the opening of the democratic space should therefore incorporate the imperative that multi-party democracy doesn't lead to the extermination of the minority ethnic group. Here, perhaps, safeguards could be put in place to secure and entrench power sharing among the two groups. Power-sharing, it must be borne in mind, was the bedrock of the Arusha Accords of 1993. The idea when the accords were brokered was that one ethnic group should not dominate the political space in Rwanda. The transition from the genocide, however, turned out to be so flawed that the situation the Arusha Accords tried to avoid is exactly what has since been entrenched in Rwanda today. Mamdani suggests that from the Arusha Accords and their failed implementation:

The lesson is to be inclusive, to recognize the right of all ideological currents without exception - to compete in the marketplace of ideas, leaving out in the cold only those unwilling to disarm as a precondition to gaining entry to the reform process (Mamdani, 2001, pp. 278-279).

It is in the so-called marketplace of ideas that the other aspects of the international community's attempt to influence durable democratic change in Rwanda should focus. The starting point here could be the country's public broadcast system. A well-funded, independent public broadcaster is probably one of the best markers of a healthy, vibrant media environment. Allowing the public broadcaster to operate with as much editorial independence as possible, without compelling its staff to serve as propagandists for the government, is a healthy sign that the government is ready to welcome and promote media pluralism. Encouraging the Rwandan regime to loosen its grip on the country's public broadcast system could be a significant step towards achieving media 
pluralism in the country. And an atmosphere of media pluralism would make it difficult, if not impossible, for extremists to take over the media landscape to use it to stir up ethnic hatred, as was the case in the period preceding the genocide:

The emphasis should be on promoting pluralism in privately owned media and supporting reform of the state broadcasting system as a means of marginalizing extremist propaganda and developing the middle ground. If useful lessons are to be drawn from the Rwandan situation it is necessary to go back to the introduction of multi-party politics and the failure to build adequate institutional support for democracy (Article 19, 1996, p. 106).

The media, and broadcast media in the particular case of Rwanda, is one of such important institutional support mechanisms for democracy to thrive. In this regard, Carver suggests that broadcast reform should be firmly on the agenda of any moves towards fixing the flaws of Rwanda's transition. Broadcast reform would also correct an anomalous colonial legacy. "For most of the post-colonial period in most African countries, the structure of broadcasting was the same," Carver says. "Formal guarantees of the structural or editorial independence of the state broadcaster, were minimal or non-existent, because the colonial models had the same defect" (Carver, 2000, p. 193).

This is the context that made it possible for both the pre- and post-genocide governments in Rwanda to use the Office Rwandais d'Information (ORINFOR) as a propaganda outfit. Recent legislative changes have turned ORINFOR into the Rwanda Broadcast Agency, which the government describes now as the country's "public broadcast” organization. A lot remains to be done, not only to ensure the independence of this agency but also to streamline the issuance of licenses to private broadcast networks:

The key policy reform which most transitions to multiparty rule have failed to realize is the transformation of state broadcasters into independent, publiclyfunded broadcasters. This can be achieved by ensuring the independence of the government board from government interference, as well as by entrenching 
editorial independence (Carver, 2000, p. 196).

Some of Rwanda's most generous bilateral donors happen to be countries with strong public broadcast traditions. These include Canada, the Netherlands, Britain and Sweden. Instead of just throwing money at the regime for general reconstruction, some of these funds could be specifically channelled into equipping and training staff of the new Rwanda Broadcast Agency. At the same time, these countries could offer technical and legal advice to the government on how to insulate the public broadcaster to keep it running without state interference or manipulation. Here the German model of using representatives of "socially significant groups" to form broadcast councils (see Humphreys, 1994) could be employed to create an independent board of governors to secure the independence of the public broadcaster.

The same idea of the "socially significant groups" could also be used to establish an impartial media regulator for Rwanda. Here once again, the support of Rwanda's international financial backers would prove invaluable in terms of providing financial support, training and other forms of technical assistance for the Rwanda Media Commission. As mentioned in the previous chapter, this commission should be more than a group of journalists monitoring and checking the performance other journalists. Rwanda's media regulator must be a quasi-judicial body made up of representatives of the various socially significant groups in the country. It should include people with knowledge of law and media regulation. This body would receive and adjudicate on complaints about media infractions, especially those pertaining to hate propaganda, using moral suasion as a first step to get the media to cease and desist from unprofessional and unethical conduct. Repeat offenders could then be subject to severe sanctions, ranging from heavy fines to outright closure. Shuttering a media organization might be seen as too drastic a measure, but it is one of the unique legal instruments that could be used to deal with the very unique 
situation Rwanda finds itself in. As drastic as it is, any decision to close down a newspaper or broadcaster should be ratified by the highest court in the land with the possibility of an appeal at the African Commission on Human and People's Rights.

One of the clearest patterns that has emerged in the examination of the Rwandan government's constriction of the public sphere is that the main targets of its doctrine of information control (see Pottier, 2002) are political parties, the media, non-governmental organizations (NGOs) and other civil society groupings. A good number of these NGOs are international agencies with resources, trained personnel and a good track record for investigating and reporting on rights abuses. Over the years, however, they have also had to grapple, like politicians and journalists, with the government's “you're with us or against us rationale” (Gready, 2011, p. 89). Gready also points out that "RPF cadre, or those with close ties to the government, have infiltrated the top jobs in local NGOs, umbrella groups and collectives" (Gready, 2011, p. 90). International pressure to get the regime to amend its ways would therefore have to include demands for the removal of most of the restrictions on NGO operations in Rwanda. The laws that allow government to take "control of the management, finances, and projects of national and international NGOs," (Gready, 2011, p. 89) need to be urgently reviewed as a first step. The government could also be impressed upon to allow NGOs like Human Rights Watch and Reporters Without Borders to operate more freely and openly in the country.

Finally, the Rwandan government needs to be warned in no uncertain terms that the world community would not tolerate the assassination or any attempts on the lives of Rwandan dissidents in exile. Granted that no serious investigation has been concluded into the killing of some these dissidents and prosecutions are underway in South Africa, for example, of suspects in the attempt on Nyamwasa's life. There have been two major international incidents recently which 
seem to provide sufficient prima facie evidence that the Kigali regime poses a risk to its exiled opponents. The first involved the British government (one of Rwanda's most generous donor nations) issuing warnings to dissidents in London that they might be at risk of possible assassination attempts (see Kron and Gettleman, 2011, May 19). The second involved a decision by Norway and South Africa to expel Rwandan diplomats for allegedly engaging in illegal activities connected to attempts to harm exiled Rwandans (See Ritter, 2012, February 13; BBC, 2014, March 12). Further investigations need to be conducted into the cases and the regime severely censured if it is indeed proven that it really poses a risk to dissidents or has been involved in assassinations. For now, though, a strong statement that such assassinations would not be countenanced might serve to save some lives. The international community could also push for the creation of an impartial international panel to investigate the assassinations of Rwandan dissidents over the past two decades.

Having identified the areas where the Rwandan government could be influenced by its multi-lateral and bilateral donors to open up the country's public sphere (the marketplace of ideas), the next question is how the regime could actually be made to respond positively to such influences. To this, there is a two-fold answer.

First, severe sanctions could be imposed on the government, starting with its most high ranking officials, including the president. Travel bans could be a good start. “Mr Kagame’s admirable self-reliance has isolated Rwanda on the continent," according to The Economist. "He has few allies and no friends. Although he vigorously pursues his admirers in Western democracies, he allows less political space and press freedom at home than Robert Mugabe does in Zimbabwe” (The Economist, 2008, August 21). If Kagame's record is so bad to be compared with Mugabe's, the least one would expect if he doesn't amend his ways is for the international community to make 
him endure some of the opprobrium that is heaped on the Zimbabwean dictator.

The second, and perhaps most effective measure to compel the Kagame government to open up the public sphere in Rwanda is to withhold or threaten to withhold aid. Rwanda is a heavily aid-dependent nation. Much of the money the government uses to secure "performance legitimation" comes from abroad. This could explain why the regime was so rattled when a number of donor nations suspended support after the publication of the United Nation's report that exposed its involvement in the D. R. Congo. Reyntjens suggests:

Acting in consortium, the country's main donors - the United Kingdom, Belgium, the Netherlands, the United States, the European Union and the World Bank should engage the Rwandan government in a discussion to establish a road map for the next decade. This road map should contain a number of clearly defined benchmarks, ranging from [the] political (such as the opening of political space for opposition parties, respect for human rights, independence of the judiciary and the restoration of media freedom) to [the] socio-economic (such as poverty alleviation, reduction of inequality, acknowledgement of the skills of smallholder peasants and respect for the urban poor). The Rwandan government and the consortium should assess progress on an annual or biannual basis, and trends toward or away from the benchmarks should lead to appropriate re-orientations of aid (Reyntjens, 2011, p. 68).

These are reasonable demands. They mean that if the government moves towards fixing the flaws of the transition, it would get more financial and economic support. If it fails, on the other hand, to open up the political space and allow free speech and other basic rights, it would be denied the external funding it so badly needs. Appropriate strategies could be put in place to ensure that withholding aid doesn't adversely affect the poorest and the most vulnerable in Rwandan society.

Besides withholding aid and imposing sanctions, leaders of the international community could take every opportunity they get to publicly speak out against the constriction of the democratic space and the repressive media regulations in Rwanda. When human rights are suspended in any country, diplomatic niceties should also be withheld in order to draw attention 
to the violations.

Whether the international community decides to shed its genocide guilt as a first step towards engaging in open dialogue or behind-the-scenes diplomatic manoeuvres to influence governance structures in Rwanda would probably be dictated by the question of why the world needs to care so much. Why should Britain, the United States, Canada or Germany be concerned with what happens thousands of miles away from their borders in a small, landlocked African country of no strategic value?

First, Rwanda is setting a bad example for the rest of Africa. Rwanda is showing other countries on the continent that human rights values, free expression in particular, could be trampled upon for as long as governments can show the world community that minimal economic progress is being made. Thus in the foreseeable future, other African governments could start using savvy international public relations firms to promote their images abroad, parading as democratic regimes while the reality at home would be a completely different situation where dissent is stifled, the media repressed and opposition stymied. Such a situation would mean that western nations would have wasted a lot of money propping up dictatorships instead of promoting democracy and human rights.

The second answer to the question of why western nations should care about the situation in Rwanda lies in our common humanity. The world stood by and watched hundreds of thousands get slaughtered in Rwanda. It was a failure of the world community to live up to its own pledge, after the Second World War, to never again allow one group to exterminate or try to exterminate another. That failure should not be repeated - not in Rwanda or anywhere else on the planet. That sort of indifference should not become an ingrained characteristic of the global system of governance. The world community therefore needs to pay much more critical attention 
to governance in Rwanda, instead of just throwing money at the regime there and hoping the problems that led to the genocide would melt away. "Ultimately, led by the United States, France and the United Kingdom, [the international community] aided and abetted genocide in Rwanda," according to Dallaire. "No amount of cash and aid will ever wash its hands clean of Rwandan blood" (Dallaire, 2003, p. 323).

Money in itself will never help prevent another violent conflict in Rwanda. But the world community could redeem itself from the guilt of its past indifference by challenging and supporting Rwanda to establish the governance institutions that reconcile its people and prevent the exclusion and discrimination that was the root cause of the genocide. The best way to wash away the genocide guilt is to speak up against authoritarianism and human rights violations, not to shut up.

An increasing number of individuals and organizations are raising red flags about the woeful governance situation in Rwanda and what it portends for its future stability. Much of the concern about the future of the country stems from the increasing authoritarianism which uses the genocide as an excuse to limit free expression and stifle dissent. "For those of us who lived in Rwanda under the Habyarimana regime, the attitude of those who are willing to postpone democratic reform in the name of economic development is disturbingly familiar," Longman says. "The willingness to forgive authoritarianism during the Habyarimana regime in the name of unity and development, made genocide possible" (Longman, 2011, pp. 42-43). As far back as 2002, the International Crisis Group warned the RPF to recognize that:

Its authoritarian actions, whatever their motivation, have worked against its own stated objectives and is creating its own opposition. The government's repression of critical voices creates a vicious circle by radicalizing the opposition both inside and outside Rwanda. A blood pact, or Igihango has even been sealed between certain heirs of "Hutu power" and survivors of the genocide. This kind of alliance 
lends a dangerous legitimacy to an armed Hutu opposition whose position regarding the genocide remains ambiguous. Given the unstable regional dynamics, the rise to power by the opposition forces and the propagation of genocide denial pose a serious threat to the stability of the country (International Crisis Group, 2002, November 13).

The most frightening of the warnings about the future of Rwanda, perhaps, comes from

Nyamwasa et al, who suggest that:

The Rwanda conflict never really ended. Rwanda may look peaceful internally, but it is a peace maintained by force of arms. As long as Rwanda is unable to resolve its governance problems, the risk of conflict remain high... As the Tutsi minority cannot hope to impose their will on the Hutu majority forever, the military victory of Hutu insurgency could, in turn, lead to the genocide of the remaining Tutsi population of Rwanda. When Rwanda shall implode, as it inevitably will unless President Kagame changes course, the implosion could have devastating consequences for Tutsi communities in other countries of the Great Lakes region of Central Africa (Nyamwasa et al, 2010).

In reflecting on these words, it is noteworthy that Nyamwasa and the three other men who wrote them are Tutsi men who once served in this government. As former members of the regime's inner core, they must surely know what they are talking about. Even if consideration is given to the fact that they may be disgruntled former regime insiders who just want to paint the government in bad light, the Kagame administration's own policies and practises appear to suggest these warning cannot and should not be ignored. If they are brushed aside and Rwanda implodes again, the international community would have failed humanity one more time. The cost of that failure in terms of money, lives and limbs would be too much to bear. It would send a message to the most imperious regimes on the planet that indifference is so ingrained in the world system that they can orchestrate any atrocity for the world to stand by and watch.

Thus, former U.N. Secretary General, Kofi Annan, emphasizes that "all of us, as diplomats, journalists, government officials or just concerned citizens, [should] act promptly and effectively, each within our sphere of influence, to halt genocide wherever it occurs - or better 
still, to make sure that there is no 'next time' (Annan, 2007, p. x). So far, almost every bit of information available seems to suggest the possibility of a "next time" in Rwanda. Staving off that bloody, genocidal "next time," demands that the international community sheds its genocide guilt, while supporting Rwanda and challenging its government to allow for greater enjoyment of fundamental freedoms, starting with the freedoms of speech and of the press. The taxpayers in those countries that provide economic assistance to Rwanda deserve better use of their money than the propping up of a regime that engages in practices that would not be tolerated in most of these countries - authoritarian tendencies that could potentially lead to another genocide. Until that risk of another genocide has been eliminated or reduced to the barest minimum, Kagame's dream for his country would remain just that - a dream. A pipe dream. 


\section{Conclusion}

\section{DRUM AND SHOUT}

The great kings of the ancient Nyiginya Kingdom, which formed the nucleus of modern Rwanda, kept a ritual drum known as the Kalinga (or Karinga). This drum embodied "the ideology of the Great Lakes region [that] a kingdom only exists when it has a dynastic drum" (Vansina, 2004, p. 48). "The king and the drum resided at the centre of the capital. Together they were the concrete manifestation of the very existence of the kingdom and its unity," (Vansina, 2004, p. 82). As the kingdom expanded, the Kalinga was decorated with the severed testicles of Hutu chiefs who had resisted peaceful attempts to bring them under the authority of the Tutsi king (or Mwami). The Kalinga was also a war drum, the beating of which often signaled a call to arms. But the rumbling sounds of that single drum were never meant to be louder than the shouts of the people.

In the $19^{\text {th }}$ century, when the central court of the king became so powerful, with courtiers seeing themselves as no longer accountable to the people, Rwandans coined a proverb: "the drum is greater than the shout." It meant, according to Des Forges, that "the power of the state exceeds that of the people" (Des Forges, 1986, p. 312). In other words, the leaders had become a power unto themselves, unwilling to tolerate dissent, much less listen to the voices of the people; the people had been placed in such a position that even when they dared to shout their dissent, their voices (the shouts of a million) were drowned out by the few voices coming out of the king's court.

After the death of Rwabugiri, the last great king who is largely credited with the expansion of the realm that is today known as Rwanda, the kingdom was wracked by the worst internecine violence in its history. Hutu fought Hutu, Tutsi battled Tutsi and, quite frequently, Hutu rose against the Tutsi-dominated central court. Rwabugiri's reign led to the "export of the [central 
court's] rivalries all across the country" while his rapid "centralization [of power] sowed terror and reaped social disaster" (Vansina, 2004, p. 195). This regime of "the law of the strongest" brought with it a "train of troubles, insecurity and clamour for revenge:"

These unending conflicts necessarily led to growing disturbances that, from the second half of the $\left[19^{\text {th }}\right]$ century onward, unsettled the country more and more. At the same time, the high nobility increasingly exploited the bulk of its subjects, and its scorn for them manifested itself more and more in their humiliating treatment of the populace. The combination of the humiliation suffered and the heavier and heavier exploitation finally provoked a rift that tore the whole society apart, so that, by 1890, it teetered on the brink of total anomy (Vansina, 2004, p. 197).

As pretenders and genuine heirs to various dynasties in the kingdom fought their way to power, it was the arrival of the colonialists (endowed with superior weaponry) that helped to separate the victors from the vanquished. Even among the elite Tutsi lords, it was those who formed alliances with the colonialists who managed to secure power. Left to only watch and bear much of the brunt of these conflicts, the ordinary people of Rwanda came to formulate an important piece of native wisdom, which was relayed to Ingalaere by “an educated member of the Hutu peasantry:"

In Rwandan tradition and custom, power is symbolised by the drum. If you put your hands on the drum, it means you have power... The only means for [others] to access the drum and thus power is to violently chop off the arm reaching for the drum and holding up those other arms. The drum comes in the hands of another and other arms are mustered to support and to be supported by the drum (quoted in Ingalaere, 2011, p. 75).

That, in a nutshell, has been the history of power and politics in Rwanda - the history that culminated in the genocide of 1994. Rwanda's Hutu and Tutsi, along with the less popular Twa group, are very familiar with the use of violence, coercion and denunciation to win and assert power. Thus it might seem that Rwanda's political and social culture doesn't encourage a peaceful transition of power from one leader to another. There was never a peaceful transition before colonialism and there has never been one since the end of colonialism. In fact, it was colonialism 
that brought a measure of stability to the plains of this country of a thousand hills. But even that was a stability maintained by force of arms. Along with an enforced peace, colonialism also brought a system which concretized the ethnic differences in the country in laws that were enforced with a religious zeal underpinned by racial bigotry. These laws, implemented with the introduction of ethnic identity cards in the 1930s, legitimized discrimination against the Hutu while privileging the Tutsi. The end of colonialism, however, turned the tables in favour of the majority Hutu. The extremists in the post-independence Hutu elite thought it necessary to use their newfound coercive powers to rid Rwanda of its Tutsi citizens. The genocide of 1994, the most significant epoch in the country's history, was meant to be the final push by these extremists to complete a project they had started in the 1960s. They failed, however, and at the end of the genocide, central power in Rwanda fell back into the hands of a Tutsi clique. In essence, drawing from the Kalinga analogy, the drum which was placed in Hutu hands at independence, has after much bloodshed, ended up in Tutsi hands again.

Rwanda's new Tutsi lords rule the country in the $21^{\text {st }}$ century like their forebears did 300 years ago. They have no qualms about using violence, coercion and denunciation, as was the case in the years of yore. They dominate the Rwandan public sphere and countenance little opposition and absolutely no dissent. Their justification is that they need to take all necessary measures to prevent extremist Hutu bigots from launching another genocide. Most of these measures have made the state such a powerful and almost unaccountable presence in their lives that in the modern era, Rwandans continue to invoke that same proverb from centuries past: "the drum is greater than the shout." Rwandans use this proverb "to explain the post-genocide present in terms of the pre-colonial past - not the [current regime's] imagined past of nonethnic harmony, but a 
past marked by the central state's political (and ethnic) domination of the periphery (Ingalaere, 2001 pp. 67-68).

The regime's heavy-handed domination of the state has resulted in a complete takeover of the public sphere in Rwanda, to the extent that people are not allowed under many circumstances to express dissent in word or deed. There are many instances of people being forced to participate in political events they would rather abstain from - all to create the impression of a reconciled nation where ethnicity means nothing to the people. After being coerced into one such engagement, some teachers complained that failure to participate would only have brought them "problems in other areas of life" (quoted in Ingalaere, 2011, p. 71).

For those who have dared to express dissent or opposition, especially in the pages of newspapers, "the problems in other areas of life" have come in many forms - prosecution, persecution, denunciation, imprisonment, exile and even assassination. Many Rwandans have noticed these "problems" and have taken a frustrated consolation in the hope that the drum would someday change hands again. In Rwanda it always does and, often, with a lot of bloodshed. That, unfortunately, seems to be a reality ingrained in the country's body politic. It's a fact the current government is well aware of, yet has done very little, if anything, to change. Instead, it chooses to ignore warnings from all sides that the path it has taken could lead to further bloodshed sooner or later.

The regime appears to be convinced that delivering a strong economy would end Rwanda's history of violent transitions, enhance its legitimacy and excuse much of its excesses, marked by the authoritarian streak that severely limits the enjoyment of constitutionally guaranteed free expression. While it has done remarkably well to take the Rwandan economy out of the doldrums of genocidal destruction, the current regime, it seems, has lost sight of the fact 
that its economic record is not very different from that of the regime it replaced. As Straus and

Waldorf suggest:

The stability, order and growth in contemporary Rwanda are not new when viewed in historical perspective. After all, pre-genocide Rwanda was a donor darling praised for many of the same qualities as the current regime (Waldorf, 2011, p. 7).

Habimana is also skeptical about the notion that economic development would save the country from future conflict:

Clean and shiny cities are a luxury no citizen would complain about, but they are ephemeral assets and could hardly constitute a priority for a society prone to cyclical political turmoil. What would really help Rwanda emerge from the ashes of a violent and discredited past is the building of strong institutions capable of safeguarding the rights and freedoms of all (Habimana, 2011, p. 356).

Moreover, as Kinzer points out Kagame is not the first African leader to rule with an iron fist, suppressing dissent while trying to compensate for his excesses with economic and infrastructural development. All previous African leaders who took this path failed woefully:

No one who sees great potential in any African leader can ignore the abysmal record of former heroes. Many of the most revered founding fathers of postindependence Africa, like Nkrumah and Jomo Kenyatta, came to power amid limitless hopes but left their countries poorer, weaker and more divided than they found them. Leaders of anticolonial revolutions, most vividly, Robert Mugabe of Zimbabwe, were hailed as liberators but became oppressors. Yoweri Museveni, the Ugandan leader who was Kagame's mentor for many years and was considered one of the "dashing warrior princes" who would revolutionise Africa, clung to power for decades and fell into the familiar vices of corruption, nepotism and egomania. Naïve outsiders, eager for success stories from Africa, are quick to praise any promising leader (Kinzer, 2008, p. 5).

Thus, in African history, steady economic growth and infrastructural development have often failed to bring unity and erase sectarian grievances. Therefore, if an impressive economic record could not save the Habyarimana regime from an RPF insurgency, the RPF would be deluding itself if it sincerely believes it can cover up its authoritarian excesses by making Rwanda the 
"Singapore of Africa" (The Economist, 2012, February 25). An insurgency has been simmering on the country's borders, with remnants of the former Interambwe militia waiting for the right moment to strike. They have been recruiting new members, including children who are being indoctrinated to hate people of Tutsi ethnicity. "The Tutsi stole our country and they are killing the Hutu or making them slaves," one child soldier is quoted as saying from a camp in the Democratic Republic of Congo. "We have to kill them wherever they are. It is the only way to get our country back. When they are defeated I can go home," (quoted in McGreal, 2008, May 16). It is against people like these that the Rwandan Army has been fighting what Reyntjens describes as a "civil war abroad:"

Although the Rwandan civil war formally ended with the RPF's victory in July 1994, the flight of the defeated Rwandan Armed Forces (FAR), the militia and more than one million civilians to [the Democratic Republic of Congo] exported the conflict. When the FAR entered [the Democratic Republic of Congo] in July 1994, they were only partly disarmed, and some of the weapons and ammunition seized were later resold to them by the Zairean Armed Forces. Until 1996, military equipment continued to reach them in the Goma region, despite an embargo decreed by the UN Security Council. These "refugee warriors" were not just the passive beneficiaries of international assistance but also actors in their own right with a clear goal in mind: they intended to recapture power in Rwanda. For a number of these Rwandans, this objective probably included finishing an unfinished job: the genocide (Reyntjens, 2011, p. 133).

Finishing off the genocide or getting the Tutsi out of Rwanda remains an attractive option for many Hutu, who "perceive the RPF as an instrument of political domination by the minority" (Nyamwasa et al, 2010). An attempt at a violent takeover, would appear inevitable for as long as the current regime in Kigali holds on firmly to power and fails to deliver genuine reconciliation between Rwanda's two main ethnic groups.

Rwandans today are very far from reconciled. That's a fact even the country's much touted economic progress cannot hide because it benefits only a few (see Thomson, 2011). 
Reyntjens (2010) also asserts that even among the few who benefit from the government's economic policies, the majority are Tutsi. It would therefore appear that the current regime has done very little to dismantle the infrastructure of exclusion that has been a key feature of Rwanda's history, leaving the country as vulnerable as ever to ethnic strife. Furthermore, the prohibition on public references to ethnicity, a cornerstone of the government's reconciliation policy, has rather served to highlight ethnic divisions in the country. The policy has failed because, to begin with, it was based on the fallacy that it was colonialism that introduced ethnicity to Rwanda. But as Vansina points out:

The linguistic and cultural unity of the country today did not exist in the $17^{\text {th }}$ century and Rwanda is not a "natural" nation. It is the product of the expansion of the culture of the Nyiginya court that began in the $18^{\text {th }}$ century but occurred mainly in the $19^{\text {th }}$ and early $20^{\text {th }}$ centuries. Rwanda really became a nation in the $20^{\text {th }}$ century... Formerly, neither abundance nor order flourished in the country and it is false to think that everyone was happy with their station in life and all lived in peace under the shepherd's staff of wise kings. False, not only because it runs counter to the evidence, but also because it is biased, for it only reflects the point of view of a well-off courtier. And, in any event, the perpetual struggles among the big men at court rendered such moments of harmony practically nonexistent (Vansina, 2004, p. 198).

Determined, however, to rewrite Rwanda's history (see Pottier, 2002), the government is sticking to an erroneous notion of a past of harmonious co-existence of Rwandans, a past era when ethnicity wasn't supposedly an issue. All this, ostensibly, to promote reconciliation and peaceful co-existence. But, as Thomson points out, the second reason why this policy has yielded little to no dividends has to do with the fact that:

In romanticizing the historical past, the policy relies on two broad simplifications: all Tutsi are innocent victims or 'survivors' and all Hutu (whether they participated in the genocide or not) are guilty perpetrators. As a result of its predication on this simplistic dichotomy, Rwanda's national unity and reconciliation can only be maintained through the extensive policing of public speech (Thomson, 2011, p. 443). 
This "policing of public speech," in essence, is the basis of the severe restrictions on free speech in Rwanda and the government's utter domination of the country's public sphere. On paper, there are laws that outlaw censorship and appear to grant Rwandan journalists much of the same rights and freedoms their counterparts in other democratic nations enjoy. The constitution, for example, guarantees press freedom and free speech. In practice, however, the regime uses vaguely drafted laws, to make a mockery of the constitutional guarantee of free speech and press freedom. Instead of fulfilling the constitution, these laws flout the very constitution the government has sworn to uphold. And, in the circumstance where the country's courts have become instruments in the hands of the regime, it is fanciful to imagine a situation where a court in Rwanda would strike down any legislation as unconstitutional. In the circumstance, it is easy for the regime to use the law to suppress, intimidate and harass journalists while dominating the Rwandan public sphere. Both the repression and the domination of the public sphere reflect the most threatening malaise in Rwanda's body politic - the same malaise of coercion and exclusion that culminated in the genocide of 1994.

The transition after the genocide was supposed to move Rwanda towards a cure. But it didn't. This was because the regime used the guilt of the international community over its failure to help prevent the genocide to impose "a dangerously flawed political governance" (Reyntjens, 2010, p. 32), the most obvious symptom of which is the clampdown on free expression. In response to the suppression of expression, Rwandans have adopted their own practices of resistance. These range from "staying on the sidelines" to "irreverent compliance" and “withdrawn muteness" (Thomson, 2011, pp. 449-453):

Because peasant Rwandans have no opportunity to express themselves politically in public, their everyday practices in response to demands of the policy [of 
reconciliation] demonstrate how they tactically conceal or reveal their political opinions. When they express no opinion, and therefore appear compliant, many casual observers conclude that peasant people believe in and support the regime. Their everyday acts of resistance illustrate the opposite... Identification of the individual acts of resistance of the most marginal in a stratified society such as post-genocide Rwanda points analysts towards areas where political life can quickly descend from the appearance of compliance to open protest and perhaps onto revolution or even genocide (Thomson, 2011, pp. 455-456).

Correcting the flaws of the transition that made it possible for the RPF to impose its will and its truth on Rwandans, could help prevent the country from sliding into a situation, where violence could be used, once again, to change the hand that wields the king's drum. Genuine reconciliation and good governance, marked by guarantees of basic rights, starting with free speech and press freedom, would make it unattractive for the Hutu masses to lend their support to extremist elements who still yearn for a day when Rwanda would be rid of its Tutsi citizens. In this regard, the media, endowed with legal guarantees of freedom of speech, could contribute a great deal towards good governance, the enjoyment of fundamental human rights and genuine reconciliation.

On the news media specifically, Christians et al identified four key roles journalists can play in the creation and sustenance of a durable functioning democracy. The first of these is the "monitorial" role, which "refers to all aspects of the collection, processing and dissemination of information of all kinds about current and recent events, plus warnings about future developments" (Christians et al, 2009, p. 125). Secondly, there is the "facilitative" role, which draws on the theory of the public sphere to produce "a journalism that is deliberately practiced as a means of improving the quality of public life and contributing to deliberative forms of democracy" (Christians et al, 2009, p. 126). By fulfilling the facilitative role, journalists:

Promote inclusiveness, pluralism and collective purpose. According to the concept of the facilitative role, they help to develop a shared moral framework for 
community and society, rather than just looking after individual rights and interests. The latter are treated as subordinate to a larger good, which itself must not be manifested by decree but developed by way of public communication (Christians et al, 2009, p. 126).

The third role of journalism in a democratic society is the "radical" role. This, according to Christians et al, "focusses on exposing abuses of power and aims to raise popular consciousness of wrongdoing, inequality, and the potential for change" (Christians et al, 2009, p. 126). This is largely a political role, which "tends to be fulfilled by a minority sector of the printed press that represents some social or political movement and advocates radical opinions and policies along partisan lines" (Christians et al, 2009, pp. 126-127).

Finally, Christians et al also identified the "collaborative" role, which:

Specifies and values the tasks for media that arise in situations of unavoidable engagement with social events and processes. Typical situations where this role is appropriate are those of new nations, with their intense pressure toward economic and social development under conditions of scarce resources and immature political institutions. However, collaboration between the media and the state is often advocated, if not mandated, under unusual conditions of crisis or emergency or threat to the society, from external or internal causes. Terrorism and war are obvious examples of such situations, but natural disasters and crises of crime, health and safety lead in the same direction. Even under normal conditions, there is usually a latent or partial system of cooperation between the media and organs of government and the state that produce voluntary collaboration (Christians et al, 2009, p. 127).

Together, all of these roles help democracies flourish. In Rwanda, however, the government tends to insist on, if not legally mandate, the collaborative role. In most cases, the collaborative role has been perverted into outright co-optation, with the government's constant manipulation of the genocide as justification for the country to essentially be on constant guard against a future genocide. At the same time, the radical role is strictly prohibited while the government appears to subscribe to a policy of frustrating both the facilitative and monitorial roles, albeit to varying degrees. 
The prohibitions and the frustrations journalists endure as they struggle to play their roles in Rwanda's so-called democracy have reinforced the exclusion and the discrimination the government claims to be addressing to avert future calamity. Stifled, shackled and monopolized by the government, the Rwandan media therefore reflects the abysmal state of free expression in the country - not just for journalists, but also for politicians, activists and even ordinary, well-meaning citizens. The suppression of free speech in turn points to weaknesses in the country's democratic foundations, which could crumble under the weight of ethnic exclusion and political repression. Free expression, therefore, is a prerequisite for peace in Rwanda. It is a cure for the country's malaise, not the curse that brought it about.

Emerson provides a treatise on the important contributions free speech can make towards the establishment of democratic, stable and peaceful nations. Firstly, according to Emerson, free speech promotes "individual self-fulfillment," which is the ability of every human being to develop his or her own personality:

From this it follows that every man - in the development of his own personality has the right to form his own beliefs and opinions. And it also follows that he has the right to express these beliefs and opinions. Otherwise, they are of little account. For expression is an integral part of the development of ideas, of mental exploration and of the affirmation of self. The power to realize his potentiality as a human being begins at this point and must extend at least this far if the whole of nature of man is not to be thwarted (Emerson, 1963, p. 879).

Secondly, Emerson points out that free expression leads to the "attainment of truth," which is to say that truth is not what the government says it is, but what an individual determines for himself to be the truth after hearing all available sides of an argument or proposition:

Suppression of information, discussion or the clash of opinion prevents one from reaching the most rational judgment, blocks the generation of new ideas and tends to perpetuate error... Discussion must be kept open no matter how certainly true an accepted opinion may seem to be. Many of the most widely acknowledged truths have turned out to be erroneous. Many of the most significant advances in 
human knowledge - from Copernicus to Einstein - have resulted from challenging hitherto unquestioned assumptions. No opinion can be immune from challenge (Emerson, 1963, pp. 881-882).

Emerson's third theory on the imperative of free expression in democratic nations stipulates that free expression promotes "participation in decision making," which is the "process for formulating common decisions" (Emerson, 1963, p. 882). In other words, freedom of expression provides a feedback mechanism through which the government can inform itself about the needs and aspirations of its people. "The greater the degree of political discussion allowed, the more responsive is the government, the closer [it is] brought to the will of its people, and the harder must it strive to be worthy of their support:"

The crucial point, however, is not that freedom of expression is politically useful, but that it is indispensable to the operation of a democratic form of government. Once one accepts the premise that governments derive "their just powers from the consent of the governed," it must follow that the governed must, in order to exercise their right of consent, have full freedom of expression both in forming their individual judgments and in forming the common judgment (Emerson, 1963, p. 883).

Finally, and, perhaps, most important and relevant to Rwanda, Emerson posits that freedom of expression ensures a "balance between stability and change." He explains that "the principle of open discussion is a method of achieving a more adaptable and at the same time more stable community, of maintaining the precarious balance between healthy cleavage and necessary consensus:"

Suppression of expression conceals the real problems confronting a society and diverts public attention from the critical issues. It is likely to result in neglect of the grievances which are the actual basis of the unrest, and thus prevent correction. For it both hides the extent of opposition and hardens the position of all sides, thus making a rational compromise difficult or impossible. Further, suppression drives opposition underground, leaving those suppressed either apathetic or desperate. It thus saps the vitality out of the society or makes resort to force more likely. And finally, it weakens and debilitates the majority, whose support for the common decision is necessary (Emerson, 1963, p. 884). 
Emerson published these theories more than 50 years ago, but they seem to have been presciently postulated for the state of Rwanda today. The exiled (underground) opposition, the "fear" that pervades the political space (see Longman, 2011), the botched reconciliation program (Thomson, 2011), peasants on the sidelines and Rwanda's involvement in D.R. Congo coupled with its constant (or default) positioning on a war footing and the government's increasing alienation of its own Tutsi constituency (the population it claims to be protecting) are all symptoms of an ailing nation. If Emerson's postulations and the roles of journalism outlined by Christians et al (2009) are anything to go by, the argument could be made that one of the best ways to heal Rwanda of its malaise of ethnic animosity and suspicion would be for the government to open up the public sphere, increase the political space and allow for greater public involvement in decisions about the future of the country. In other words, the government should allow and encourage "reflection and deliberation about alternatives" (see Luckert and Bachrach, 2009, p. 32). This would go a long way to remove the spectre of exclusion that has for centuries been the bane of Rwanda.

Increased public participation in decision making would necessarily entail an active promotion of the right of free expression and institutional arrangements that would prevent a small clique from any particular ethnic group from monopolizing power. Peaceful transitions of power would become the norm and power would be attained and utilized in the interest of all Rwandans - not for any particular ethnic group. Ethnicity could be minimized in Rwanda to nearirrelevance if power stops privileging one ethnic group while discriminating against the other. Getting to this points demands the important first step of fostering press freedom and free speech, which, as the constitution stipulates, is guaranteed for all Rwandans. 
The only restriction on this right would be the absolute prohibition of hate speech - those messages that aim to get one ethnic group to visit violence on another. Many countries around the world, place restrictions on hate speech. And it is perfectly within the right of the Rwandan government to take steps to clamp down on hate speech and ethnic propaganda. Using broadly formulated laws, such as the legislation on "genocide ideology" in Rwanda, however is disproportionate, unreasonable and counterproductive (see Longman, 2011). Such legislation, also tend to make a mockery of the constitutional guarantee of free speech, the enjoyment of which is a fundamental basis for both democracy and reconciliation in Rwanda. This is because free speech would lay many of the controversial, taboo issues in this ethnically divided nation bare. But with an independent judiciary and impartial law enforcement, such divisions would only show up as what Emerson describes as a "healthy cleavage," which could lead to the "necessary consensus" (1963, p. 884). Without this necessary consensus of Hutu and Tutsi alike agreeing on the future of the nation, Rwanda may never rid itself of ethnic acrimony. In other words, instead of brushing the ethnic issue under the carpet and prohibiting ethnicity, Rwandans could be allowed to talk about their ethnic identities while being helped to build a unique tapestry of nationhood where both the majority and minority groups are meshed into a vibrant, growing nation at peace with itself.

The Potemkin democracy that has been foisted on Rwanda is only a smokescreen that makes it almost impossible for Rwandans to speak their minds and engage in an open, honest conversation with each other about the future of their country. There are no avenues for them to genuinely express their opinions and even when they do, they stand the risk of prosecution and imprisonment for saying things any government official considers to be offensive or divisive. 
Thus, Rwanda, is a classic example of an "illiberal democracy" (Zakaria, 1997), one of whose main characteristics is the suppression of free expression, most notably by using the law and the state's coercive machinery to intimidate journalists and civic society. The larger risk in Rwanda's brand of "illiberal democracy" is that many of those who suffer its harshest effects are from one ethnic group. Hutu politicians and journalists are the ones who often get jailed. Most of the journalists and dissidents who have fled into exile have been overwhelmingly Hutu. And since political power is largely in the hands of Tutsi, in this nation where a very pronounced ethnic dichotomy led to genocide, the restrictions on media and free expression reinforce Hutu beliefs that the Tutsi are alien oppressors. Instead of cementing the peace, as the government believes itself to be doing, the suppression of expression is widening the wedge between the two ethnic groups. In other words, the restrictions on free expression in Rwanda are working against the development of bonds of "social empathy" (Schudson, 2008) - that situation where individuals and groups in society get to know and appreciate each other's view points, fears and aspirations. "Social empathy" provides "a link between private troubles and public issues," and "encourages empathy and understanding in the audience" (Schudson, 2008, pp. 18, 19). It might seem that social empathy is one of the prerequisites for reconciliation, which is something Rwanda so badly needs if it is to avoid another conflict. But social empathy is almost impossible to create when the government dominates the media space with its propaganda and punishes anyone who challenges the regime's version of the truth. Partly as a result of the absence of social empathy in their country, Rwandan are far from reconciled. As Thomson points out despite the regime's monopoly of the public sphere, imposing its truth and coercing the population to do its bidding, Rwandans know all is not well with their nation: 
Rwandans do not believe in the policy of national unity and reconciliation - their perceived compliance with its dictates is tactical rather than sincere... There has been no frank or open discussion of how ethnic categories shaped the violence of the genocide, nor has there been any official recognition of lived experiences that differ from the official version, in which only Tutsi were victims and only Hutu killed. Nor does the RPF allow public acknowledgment of the existence or experience of Tutsi and Twa perpetrators, Hutu and Twa rescuers; Tutsi, Hutu, and Twa resisters or Hutu and Twa survivors. Tutsi are rightfully and correctly survivors of genocide, as they were targeted by virtue of their ethnicity, but all Rwandans are survivors of conflict, jostled and shaped by traumatic events over which they had little or no control (Thomson, 2011, pp. 440 \& 445).

Thus the policies and practices the government of Rwanda has adopted to supposedly promote reconciliation have rather institutionalized and legalized the oppression of many of Rwanda's citizens - Hutu, Tutsi and Twa alike, but the Hutu more so. This means that the government has little to no legitimacy among the majority Hutu population (see Nyamwasa et al, 2010). As Reytenjens, says the regime's clampdown on the media is an indication of "a deep sense of insecurity" borne out of the fact that "it could not afford to face open political competition on a level playing field” (2010, p. 67). To bolster its legitimacy, the regime turns to the international community, using propaganda, "performance legitimation" (Longman, 2011) and the "genocide credit” (Pottier, 2002; Reyntjens, 2004).

Western governments, therefore, give the façade of democracy in Rwanda a gloss of legitimacy, frustrating any attempts by Rwandans to bring about peaceful change in their country. This is against the background that citizens of the western nations that provide the bulk of the economic aid that sustains Rwanda would not countenance any of the repression in Rwanda in their own countries. Britons won't sit idle for opposition leaders to be jailed on trumped up charges. Americans will not countenance any government policy that limits their right to free speech and Germans won't condone a state monopoly over the public sphere. Yet the governments of western nations: 
Have been passive and pliant, thereby enabling the RPF's repression, exclusion and social engineering. Once again, the development enterprise is underwriting and legitimizing inequality and exclusion - as it did in the 1980s (Straus and Waldorf, 2011, p. 15).

There is much the international community could do to prevent the drum of power in Rwanda from violently changing hands in the future. The starting point would be to demand urgent reforms, as preconditions for further budgetary support (see Reyntjens, 2011). Such reforms should make it possible for others to contest for power in free, democratic elections devoid of government manipulation. Sebarenzi, the exiled former speaker of Rwanda's parliament insists:

Rwanda is increasingly seen not as a nation emerging steadily out of the division of the past but as a country at risk of another cycle of violence. Rwanda's major donors have a moral obligation to forcefully use their leverage on President Kagame. Rwanda is so dependent on the international community that Kagame would not resist its demands for reforms, especially if his fears and concerns are taken into consideration. International engagement would not only help achieve the peace that Rwandans long for, but would also help [bring] justice and human rights for all Rwandans (Sabarenzi, 2011, p. 352).

In the final analysis, Rwanda's post-genocide governments (the current regime and those which would come after it) need to appreciate the fact that diversity is not a problem in and of itself. Differences in opinion, ethnic origin and political ideology do not necessarily lead to bloody conflicts. It is only when these differences are manipulated to set one group against another, with one group portrayed as the cause of the problems of the wider society that violent ruptures occur. And in most cases, such manipulation is engineered by the elite, those who wield or seek to wield power, as Rwanda's examples even from the pre-colonial era demonstrate. It is the tendency to set one ethnic group against another that needs to be curtailed to ensure lasting peace in Rwanda.

Any attempt to completely erase ethnicity from the country is as futile as it is dangerous and self-serving, considering that it is mostly used to hide that fact that a Tutsi elite has become the "new Akazu," holding all of the country's institutions, including the media, in a vice-like grip 
(see Reyntjens, 2004). The regime's own annual elaborate genocide commemorations, remind Rwandans every year that they are either Hutu or Tutsi. From April to July every year, Rwandans are told never to forget about how the Hutu tried to exterminate the Tutsi, only for the regime to turn around to tell its citizens not to refer to their ethnic identities from August to March.

Ethnicity is an important facet of the social and cultural fabric of almost every African country, including Rwanda. It cannot be legislated into oblivion.

Moreover, it is well-nigh impossible to get the citizens of a nation of 11 million to think as one and act like a herd of sheep, following a government prescribed ideology. Nation building entails an appreciation and toleration of the diversity affiliations, identities and voices within the territory. Any attempt to suppress these, would breed suspicion and tension both of which could result in undesirable social rupture. Even in small family units partners and their offspring cannot be expected to be in constant agreement with each other. The husband would think differently on any given issue from the wife, whose opinions may not be shared by the first son who in turn cannot expect his younger sister to share in all his beliefs. It is how these disagreements are resolved, allowing the community to come to a consensus almost everyone can live with that tames the instinct to resort to violence or coercion. Similarly, a nation like Rwanda can manage and make positive use of the different ethnic identities of its citizens not by imposing an "ethnic amnesia” (see Reyntjens, 2010, p. 30) on them, but by granting each citizen, regardless of his ethnic affiliation, an equal voice and an equal opportunity to participate in the management of the affairs of the nation. When the people have a voice and they know they can speak out about their grievances, and even occasionally have them addressed, the risk that they would resort to violence would be significantly reduced. 
In a situation where the government imposes its will, refuses to countenance opposition, stifles dissent and suppresses free expression, consensus is what the government say it is - the drum becomes louder than the shout. And in such circumstances, Rwandans know that it is not a matter of if, but when the hand that wields the drum would be chopped off for a new set of hands to take over. To prevent the drum from changing hands in another spasm of bloody conflict, the reasonable first step would be to expand the frontiers of free expression, allowing the shouts of the people to overshadow the rumblings of the government's drum. That would be another epoch in the nation's history, but it could be the start of the era that brings durable peace to the thousand hills of Rwanda. 


\section{REFERENCES}

\section{Books}

Alexis, M., \& Mpambara, I. (2003). The Rwandan media experience from the genocide. Copenhagen: International Media Support. Retrieved February 2, 2013, from http://www.i-m-s.dk/wpcontent/uploads/2012/11/ims-assessment-rwanda-genocide-2003.pdf

Anyidoho, H. K. (1997). Guns over Kigali: The Rwandese civil war - 1994. Accra: Woeli Publishing Services.

Article 19. (1996). Broadcasting genocide: Censorship, propaganda and state-sponsored violence in Rwanda 1990-1994 [PDF]. Retrieved December 11, 2013, from http://www.article19.org/resources.php/resource/28/en/rwanda:-broadcastinggenocide---censorship,-propaganda-and-state-sponsored-violence-in-rwanda-1990-1994

Berger, A. A. (1995). Essentials of mass communication theory. Thousand Oaks: Sage Publications.

Bytwerk, R. L. (2001). Julius Streicher: Nazi Editor of the Notorious Anti-Semitic Newspaper Der Stürmer. New York: Cooper Square Press.

Christians, C. G., Glasser, T. L., McQuail, D., Nordenstreng, K., \& White, R. A. (2009). Normative theories of the media: Journalism in democratic societies. Urbana: University of Illinois Press.

Chrétien, J. (2006). The Great Lakes of Africa: Two thousand years of history (S. Straus, Trans.). New York: Zone Books.

Crisafulli, P., \& Redmond, A. (2012). Rwanda, Inc.: How a devastated nation became an economic model for the developing world. New York: Palgrave Macmillan.

Croteau, D., \& Hoynes, W. (2014). Media/society: Industries, images, and audiences (5th ed.). Thousand Oaks, CA: Pine Forge Press. 
Dallaire, R. (2004). Shake hands with the devil: The failure of humanity in Rwanda. Toronto: Random House Canada.

Des Forges, A. (1999). Leave none to tell the story. New York: Human Rights Watch.

Frère, M. (2007). The media and conflicts in Central Africa. Boulder, CO: Lynne Reinner.

Fullbrook, M. (1990). A Concise History of Germany. Cambridge, UK: Cambridge University Press.

Gourevitch, P. (1998). We wish to inform you that tomorrow we will be killed with our families: Stories from Rwanda. New York: Picador.

Habermas, J. (1996). The Habermas reader (W. Outhwaite, Ed.). Cambridge, UK: Polity Press.

Hatzfeld, J. (2005). Machete season: The killers in Rwanda speak (L. Coverdale, Trans.). New York: Farrar, Straus and Giroux.

Humphreys, P. (1994). Media and media policy in Germany: The press and broadcasting since 1945 (2nd ed.). Oxford: Berg.

Jowett, G. S., \& O'Donnell, V. (1999). Propaganda and persuasion (Third ed.). Thousand Oaks, CA: Sage Publications Incorporated.

Kalyango, Y., Jr. (2011). African Media and Democratization. New York: Peter Lang.

Kinzer, S. (2008). A thousand hills: Rwanda's rebirth and the man who dreamed it. Hoboken, NJ: John Wiley \& Sons.

Kitchen, M. (2006). A History of Modern Germany: 1800-2000. Malden, MA: Blackwell.

Kovach, B., \& Rosenstiel, T. (2007). The elements of journalism: What news people should know and what the public should expect (2nd ed.). New York: Three Rivers Press.

Kuperman, A. J. (2001). The limits of humanitarian intervention: Genocide in Rwanda. Washington, D.C.: Brookings Institution Press.

Lewis, D. (2001). Contemporary Germany: A handbook. London: Arnold. 
Lowery, S. A., \& DeFleur, M. L. (1995). Milestones in mass communication research. New York: Longman.

Luckert, S., \& Bachrach, S. (2009). State of Deception: The Power of Nazi Propaganda. Washington, DC: United States Holocaust Memorial Museum.

Mamdani, M. (2001). When victims become killers: Colonialism, nativism, and the genocide in Rwanda. Princeton: Princeton University Press.

McQuail, D. (2005). McQuail's mass communication theory (Fifth ed.). London: Sage Publications.

Melvern, L. (2004). Conspiracy to murder: The Rwanda genocide. London: Verso.

Mushikiwabo, L., \& Kramer, J. (2006). Rwanda means the universe: A native's memoir of blood and bloodlines. New York: St. Martin's Press.

Pottier, J. (2002). Re-Imagining Rwanda: Conflict, survival and disinformation in the late twentieth century (African Studies). Cambridge: Cambridge University Press.

Prunier, G. (1995). The Rwanda crisis: History of a genocide. New York: Columbia University Press.

Sandford, J. (1976). The Mass Media of the German-Speaking Countries. London: Oswald Wolff.

Schudson, M. (2008). Why democracies need an unlovable press. Cambridge: Polity Press.

Siebert, F. S., Peterson, T., \& Schramm, W. (1956). Four theories of the press. Chicago: University of Illinois Press.

Taylor, P. M. (2003). Munitions of the mind (Third ed.). Manchester, UK: Manchester University Press.

Vansina, J. (2004). Antecedents to modern Rwanda: The Nyiginya Kingdom (Africa and the Diaspora). Madison: University of Wisconsin Press. 


\section{Chapters and anthologies}

Annan, K. (2007). Message to the symposium on the media and the Rwanda genocide. In A. Thompson (Ed.), The media and the Rwanda genocide (pp. IX-X). London: Pluto.

Biju-Duval, J. (2007). 'Hate media' - Crimes against humanity and genocide: Opportunities missed by the International Criminal Tribunal for Rwanda. In A. Thompson (Ed.), The media and the Rwanda genocide (pp. 343-361). London: Pluto Press.

Carver, R. (2000). Broadcasting and political transition: Rwanda and beyond. In R. Fardon \& G. Furniss (Eds.), African broadcast cultures: Radio in transition (pp. 188-197). Oxford: James Currey.

Dallaire, R. (2007). The media dichotomy. In A. Thompson (Ed.), The Media and the Rwanda genocide (pp. 12-19). London: Pluto Press.

Des Forges, A. (1986). 'The drum is greater than the shout': The 1912 rebellion in northern Rwanda. In D. Crummey (Ed.), Banditry, rebellion and social protest in Africa (pp. 311-331). London, UK: James Currey.

Des Forges, A. (2007). Call to genocide: Radio in Rwanda, 1994. In A. Thompson (Ed.), The Media and the Rwanda genocide (pp. 41-54). London: Pluto Press.

Gready, P. (2011). Beyond "you're with us or against us": Civil society and policymaking in postgenocide Rwanda. In S. Straus \& L. Waldorf (Eds.), Remaking Rwanda: State building and human rights after mass violence (pp. 87-100). Madison, WI: University of Wisconsin Press.

Habimana, A. (2011). The dancing is still the same. In S. Straus \& L. Waldorf (Eds.), Remaking Rwanda: State building and human rights after mass violence (pp. 354-358). Madison, WI: University of Wisconsin Press. 
Higiro, J. (2007). Rwanda: Private print media on the eve of the genocide. In A. Thompson (Ed.), The media and the Rwanda genocide (pp. 73-89). London: Pluto Press.

Ingelaere, B. (2011). The ruler's drum and the people's shout: Accountability and representation on Rwanda's hills. In S. Straus \& L. Waldorf (Eds.), Remaking Rwanda: State building and buman rights after mass violence (pp. 67-78). Madison, WI: University of Wisconsin Press.

Kabanda, M. (2007). Kangura: The triumph of propaganda refined. In A. Thompson (Ed.), The media and the Rwanda genocide (pp. 62-72). London: Pluto Press.

Kamilindi, T. (2007). Journalism in a time of hate media. In A. Thompson (Ed.), The media and the Rwanda genocide (pp. 136-142). London: Pluto Press.

Li, D. (2007). Echoes of violence: Considerations on radio and genocide in Rwanda. In A. Thompson (Ed.), The media and the Rwanda genocide (pp. 90-109). London: Pluto Press.

Longman, T. (2011). Limitations to political reform: The undemocratic nature of transition in Rwanda. In S. Straus \& L. Waldorf (Eds.), Remaking Rwanda: State building and buman rights after mass violence (pp. 25-47). Madison, WI: University of Wisconsin Press.

Mironko, C. (2007). The effect of RTLM's rhetoric of ethnic hatred in rural Rwanda. In A. Thompson (Ed.), The Media and the Rwanda Genocide (pp. 125-135). London: Pluto Press.

Monasebian, S. (2007). The pre-genocide case against Radio-Télévision Libres des Mille Collines. In A. Thompson (Ed.), The media and the Rwanda genocide (pp. 308-329). London: Pluto Press.

Pillay, N., Møse, E., \& Gunawardana, A. (2007). The verdict: Summary judgment from the Media Trial. In A. Thompson (Ed.), The media and the Rwanda genocide (pp. 277-307). London: Pluto Press. 
Scanlon T. (1996). A theory of free expression. In D. Dyzenhaus \& A. Ripstein (Eds.), Law and morality: Readings in legal philosophy (pp. 517-535). Toronto: University of Toronto Press.

Sebarenzi, J. (2011). Justice and human rights for all Rwandans. In S. Straus (Ed.), Remaking Rwanda: State building and human rights after mass violence (pp. 343-353). Madison, WI: University of Wisconsin Press.

Straus, S., \& Waldorf, L. (2011). Seeing like a post-conflict state. In S. Straus \& L. Waldorf (Eds.), Remaking Rwanda: State building and buman rights after mass violence (pp. 3-23). Madison, WI: University of Wisconsin Press.

Waldorf, L. (2007). Censorship and propaganda in post-genocide Rwanda. In A. Thompson (Ed.), The media and the Rwanda genocide (pp. 404-416). London: Pluto Press.

Waldorf, L. (2011). Intrumentalizing genocide: The RPF's campaign against "genocide ideology" In S. Straus \& L. Waldorf (Eds.), Remaking Rwanda: State building and buman rights after mass violence (pp. 48-66). Madison, WI: University of Wisconsin Press.

\section{Government publications}

Federal Republic of Germany. (1949). Basic Law of the Federal Republic of Germany (Federal Republic of Germany). Berlin. Retrieved April 15, 2013, from https://www.btgbestellservice.de/pdf/80201000.pdf

Republic of Rwanda. (2002). Law No 18/2002 of 11/05/2002: Governing the press (Rwanda, Transitional National Assembly). Kigali: Government of the Republic of Rwanda.

Republic of Rwanda. (2003). Constitution of the Republic of Rwanda (Republic of Rwanda). Kigali. Retrieved November 12, 2012, from http:/ /www.rwandahope.com/constitution.pdf 
Republic of Rwanda. (2013). Official gazette nº 10 of 11 March 2013 (pp. 28-80) (Rwanda, Parliament of the Republic of Rwanda). Kigali. Retrieved October 17, 2013, from http://www.mhc.gov.rw/fileadmin/templates/PdfDocuments/Laws/

\section{Journal articles}

Allen, J. M., \& Norris, G. H. (2011). Is Genocide Different? Dealing with Hate Speech in PostGenocide Society. Journal of International Law and International Relations, 7, 146-174. Retrieved January 13, 2013, from Hein Online.

Armijo, E. (2008). Building open societies: Freedom of the press in Jordan and Rwanda. Journal of International Media and Entertainment Law, 2(1), 105-133. Retrieved January 13, 2013.

Chege, M. (1995). Between Africa's extremes. Journal of Democracy, 6(1), 44-51. Retrieved January 11, 2014, from http:/ / muse.jhu.edu/login?auth=0\&type=summary\&url=/journals/journal_of_democrac y/v006/6.1chege.html

Emerson, T. I. (1963). Towards a general theory of the first amendment. The Yale Law Journal, 77, 877-956. Retrieved September 10, 2012.

Frère, M. (2009). After the hate media: Regulation in DRC, Burundi and Rwanda. Global Media and Communication, 5(3), 327-352. Retrieved February 20, 2013.

Gordon, G. S. (2004). A war of media, words, newspapers and radio stations: The ICTR media trial and a new chapter in the international law of hate speech. Virginia Journal of International Law, 45(1), 139-197.

Habermas, J. (1974). The public sphere: An encyclopedia article. The New German Critique, 3, 49-55. Kellow, C. L., \& Steeves, H. L. (1998). The role of radio in the Rwandan genocide. Journal of Communication, 48(3), 107-128. 
Pall, Z. (2010). Light shining darkly: Comparing post-conflict constitutional structures concerning speech and association in Germany and Rwanda. Columbia Human Rights Law Review, 42(5), 5-54. Retrieved January 13, 2013.

Reyntjens, F. (2004). Rwanda, ten years on: From genocide to dictatorship. African Affairs, 103, $177-210$.

Reyntjens, F. (2010). Constructing the truth, dealing with dissent, domesticating the world: Governance in post-genocide Rwanda. African Affairs, 110(438), 1-34.

Reyntjens, F. (2011). Behind the façade of Rwanda's elections. Georgetown Journal of International Affairs, 12, 64-69. Retrieved January 13, 2013.

Samset, I. (2011). Building a repressive peace: The case of post-genocide Rwanda. Journal of Intervention and Statebuilding, 5(3), 265-283.

Sanders, E. R. (1969). The hamitic hypothesis: Its origin and functions in time perspective. Journal of African History, 10(4), 521-532.

Straus, S. (2008). What is the relationship between hate radio and violence? Rethinking Rwanda's "radio machete" Politics \& Society, 35(4), 609-637. Retrieved November 22, 2012.

Tettey, W. J. (2001). The media and democratization in Africa: Contributions, constraints and concerns of the private press. Media, Culture and Society, 23(1), 5-31. Retrieved February 20, 2013.

Tettey, W. J. (2006). The politics of media accountability in Africa: An examination of mechanisms and institutions. The International Communication Garette, 68(3), 229-248. Retrieved March 03, 2013.

Thomson, S. (2011). Whispering truth to power: The everyday resistance of Rwandan peasants to post-genocide reconciliation. African Affairs, 110(440), 439-456. 
Whitton, J. B. (1941). War by radio. Foreign Affairs, 19(3), 584-596. Retrieved December 18, 2013.

Zahar, A. (2005). The ICTR's "media" judgment and the reinvention of direct and public incitement to commit genocide. Criminal Law Forum, 16, 33-48.

Zakaria, F. (1997). The rise of illiberal democracies. Foreign Affairs, 76(6), 22-43.

\section{Websites}

Agutamba, K. (2013, March 18). Grand victory for Rwanda media. Retrieved September 19, 2013, from http:/ / focus.rw/wp/2013/03/grand-victory-for-rwanda-media/

Amnesty International. (2010). Safer to stay silent: The chilling effect of Rwanda's laws on 'genocide ideology' and 'sectarianism' (Rep.). Retrieved February 5, 2014, from

http://www.amnesty.org/en/library/info/AFR47/005/2010

Amnesty International. (2013). Rwanda: Annual report 2013. Retrieved January 17, 2014, from http://www.amnesty.org/en/region/rwanda/report-2013

Article 19. (2013, March 18). Rwanda: Media law does not go far enough. Retrieved January 17, 2014, from http://www.article19.org/resources.php/resource/3665/en/rwanda:-medialaw-does-not-go-far-enough

BBC. (2004, June 7). From president to prison. Retrieved February 8, 2014, from http://news.bbc.co.uk/2/hi/africa/3728807.stm

BBC. (2009, December 14). Rwanda jails journalist Valerie Bemeriki for genocide. Retrieved December 7, 2012, from http://news.bbc.co.uk/2/hi/8412014.stm

BBC. (2010, June 25). Rwanda 'assassins' kill reporter Jean Leonard Rugambage. Retrieved November 28, 2012, from http://www.bbc.co.uk/news/10413793

BBC. (2014, March 12). South Africa links Rwanda diplomats to attacks. Retrieved March 15, 2014, from http://www.bbc.com/news/world-africa-26546105 
Birrel, I. (2014, January 03). Darling of the West, terror to his opponents: Meet Rwanda's new scourge - Paul Kagame. Retrieved January 9, 2014, from http:/ /www.independent.co.uk/news/world/africa/darling-of-the-west-terror-to-hisopponents-meet-rwandas-new-scourge--paul-kagame-9037914.html

Brugger, W. (2003, January 1). The Treatment of Hate Speech in German Constitutional Law. Retrieved April 9, 2013, from http://www.germanlawjournal.com/pdfs/Vol04No01/PDF_Vol_04_No_01_0144_Public_Brugger.pdf

Buck, G., \& Uwiringiyimana, C. (2013, November 17). In Rwanda, ex-Quebecker's genocide trial stokes ethnic tensions. The Globe and Mail. Retrieved November 20, 2013, from http://www.theglobeandmail.com/news/world/in-rwanda-ex-quebeckers-genocide-trialstokes-ethnic-tensions/article15477125/

Bureau of Democracy, Human Rights and Labor. (2013). Country reports on human rights practices - 2012. Retrieved January 31, 2014, from http:/ /www.state.gov/j/drl/rls/hrrpt/humanrightsreport/index.htm?year=2012\&dlid=20 4156\#wrapper

Carver, R. (1996, May 23). Shooting the messenger: The media, ethnicity and political violence in Africa. Retrieved December 25, 2013, from http://www.fxi.org.za/old\%20webpages/archives/Annual\%20General\%20Meeting/carv er.htm

Cathcart, B. (2014, January 19). Leveson gave us a test to judge the worth of a press self-regulator; let's apply it. Retrieved February 15, 2014, from 
http:/ /www.theguardian.com/commentisfree/2014/jan/19/leveson-test-judge-press-selfregulation

Chapman, J. (2011, June 9). Kagame - A benign dictator? Retrieved February 5, 2014, from http:/ / thinkafricapress.com/rwanda/kagame-benign-dictator

Committee to Protect Journalists. (2000, March 22). Attacks on the Press 1999: Rwanda.

Retrieved February 6, 2014, from http://cpj.org/2000/03/attacks-on-the-press-1999rwanda.php

Committee to Protect Journalists. (2001, March 19). Attacks on the press 2000: Rwanda. Retrieved February 6, 2014, from http://cpj.org/2001/03/attacks-on-the-press-2000-rwanda.php Committee to Protect Journalists. (2002, March 26). Attacks on the press 2001: Rwanda. Retrieved February 6, 2014, from http://cpj.org/2002/03/attacks-on-the-press-2001-rwanda.php Committee to Protect Journalists. (2003, March 31). Attacks on the press 2002: Rwanda. Retrieved February 6, 2014, from http://cpj.org/2003/03/attacks-on-the-press-2002-rwanda.php Committee to Protect Journalists. (2004, March 11). Attacks on the press 2003: Rwanda. Retrieved February 6, 2014, from https://cpj.org/2004/03/attacks-on-the-press-2003-rwanda.php

Committee to Protect Journalists. (2005, March 14). Attacks on the press 2004: Rwanda. Retrieved February 6, 2014, from http://cpj.org/2005/03/attacks-on-the-press-2004-rwanda.php Committee to Protect Journalists. (2006, February 16). Attacks on the press 2005: Rwanda. Retrieved February 6, 2014, from http://cpj.org/2006/02/attacks-on-the-press-2005rwanda.php

Committee to Protect Journalists. (2007, February 5). Attacks on the press 2006: Rwanda. Retrieved February 6, 2014, from http://cpj.org/2007/02/attacks-on-the-press-2006rwanda.php 
Committee to Protect Journalists. (2008, February 5). Attacks on the press 2007: Rwanda.

Retrieved February 6, 2014, from https://cpj.org/2008/02/attacks-on-the-press-2007rwanda.php

Committee to Protect Journalists. (2009, February 10). Attacks on the press 2008: Rwanda. Retrieved February 6, 2014, from http://www.cpj.org/2009/02/attacks-on-the-press-in2008-rwanda.php

Committee to Protect Journalists. (2011, February 15). Attacks on the press 2010: Rwanda. Retrieved February 6, 2014, from https://www.cpj.org/2011/02/attacks-on-the-press2010-rwanda.php

Committee to Protect Journalists. (2011, February 4). In Rwanda, journalists given 17 and 7 years in prison. Retrieved November 28, 2012, from http://cpj.org/2011/02/in-rwandajournalists-given-17-and-12-years-in-pri.php

Committee to Protect Journalists. (2012, February). Attacks on the press 2011: Rwanda. Retrieved February 6, 2014, from https://cpj.org/2012/02/attacks-on-the-press-in-2011rwanda.php

Committee to Protect Journalists. (2013, February). Attacks on the press 2012: Rwanda. Retrieved March 29, 2013, from https://www.cpj.org/2013/02/attacks-on-the-press-in-2012rwanda.php

The Economist. (2008, August 21). A flawed hero. Retrieved February 5, 2014, from http://www.economist.com/node/11959125?story_id=11959125

The Economist. (2010, August 5). President Paul Kagame under scrutiny. Retrieved February 6, 2014, from http://www.economist.com/node/16750119 
The Economist. (2010, June 24). Who is out to kill the dissidents? Retrieved February 6, 2014, from http://www.economist.com/node/16439016

The Economist. (2010, March 4). Divisionists beware. Retrieved November 10, 2012, from http://www.economist.com/node/15622375

The Economist. (2012, February 25). Africa's Singapore? Retrieved November 10, 2012, from http://www.economist.com/node/21548263

The Economist. (2013, September 21). Safe and sorry. Retrieved February 6, 2014, from http://www.economist.com/news/middle-east-and-africa/21586597-president-tightenshis-grip-safe-and-sorry

Economist Intelligence Unit. (2013). Democracy Index 2012 (Rep.). London: The Economist Newspaper Group.

French, H. W., \& Gettleman, J. (2010, September 30). Dispute over U.N. report evokes Rwandan déjà vu. Retrieved November 16, 2012, from http://www.nytimes.com/2010/10/01/world/africa/01 rwanda.html?pagewanted=all

French, H. W. (2007, August 27). U.N. Congo report offers new view on genocide. Retrieved November 16, 2012, from http://www.nytimes.com/2010/08/28/world/africa/28congo.html?pagewanted=all

Gasore, B. (2013, March 02). First privately-owned television station hits airwaves. Retrieved April 17, 2013, from http://www.newtimes.co.rw/news/index.php?a=64450\&i=15284

Gettleman, J. (2008, December 03). Rwanda stirs deadly brew of troubles in Congo. Retrieved November 16, 2012, from http://www.nytimes.com/2008/12/04/world/africa/04congo.html?pagewanted=all 
Gettleman, J. (2010, August 10). Rwandan leader heads to new term under shadow of repression.

Retrieved November 16, 2012, from

http://www.nytimes.com/2010/08/11/world/africa/11 rwanda.html

Gettleman, J. (2013, September 4). The global elite's favorite strongman. The New York Times.

Retrieved September 4, 2013, from

http://www.nytimes.com/2013/09/08/magazine/paul-kagame-rwanda.html

Goebbels, J. (1933, August 18). The radio as the eight great power. Retrieved December 19, 2013, from http://www.calvin.edu/academic/cas/gpa/goeb56.htm

Human Rights Watch. (1992). Rwanda: Human rights developments. Retrieved February 25, 2014, from http://www.hrw.org/reports/1992/WR92/AFW-07.htm\#P451_159300

Human Rights Watch. (2013). Rwanda: World report 2013. Retrieved January 17, 2014, from http://www.hrw.org/world-report/2013/country-chapters/rwanda?page=1

Human Rights Watch. (2014). Rwanda: World report 2014. Retrieved January 26, 2014, from http://www.hrw.org/world-report/2014/country-chapters/rwanda

International Crisis Group. (2002, November 13). Rwanda at the end of the transition: A

necessary political liberalisation. Retrieved February 11, 2014, from

http://www.crisisgroup.org/en/regions/africa/central-africa/rwanda/053-rwanda-at-theend-of-the-transition-a-necessary-political-liberalisation.aspx

International Military Tribunal. (1946, October 1). International Military Tribunal Judgment, October 1946. Retrieved April 15, 2013, from http:/ /werle.rewi.huberlin.de/IMTJudgment.pdf

IREX. (2013, April 25). Rwanda media sustainability index. Retrieved February 22, 2014, from http:/ / www.irex.org/resource/rwanda-media-sustainability-index-msi 
Kagire, E., \& Straziuso, J. (2012, October 30). Rwanda opposition leader sentenced to 8 years in prison on charges of treason, genocide denial. Retrieved October 30, 2012, from http:/ /www.theprovince.com/news/Opposition $\% 20$ leader $\% 20$ sentenced $\% 20$ years $\% 20 \mathrm{pr}$ ison $\% 20$ charges $\% 20$ treason $\% 20$ genocide/7469039/story.html

Kinzer, S. (2011, January 27). Kagame's authoritarian turn risks Rwanda's future. Retrieved October 20, 2012, from http://www.guardian.co.uk/commentisfree/cifamerica/2011/jan/27/rwanda-freedomof-speech

Kron, J., \& Gettleman, J. (2011, May 19). British police warn Rwandan dissidents of threat. Retrieved November 16, 2012, from http://www.nytimes.com/2011/05/20/world/africa/20rwanda.html?_r=0

Kron, J. (2010, June 25). Rwandan editor who accused officials in shooting is killed. Retrieved November 16, 2012, from http://www.nytimes.com/2010/06/26/world/africa/26rwanda.html Leveson, J. (2012, November 29). An inquiry into the culture, practices and ethics of the press: Executive summary and recommendations [Leveson report] (Rep. No. 0779 2012-13). Retrieved February 17, 2014, from The Stationery Office website: http://www.officialdocuments.gov.uk/document/hc1213/hc07/0779/0779.asp

Longman, T. (2012, June 29). After genocide, stifled dissent. Retrieved November 16, 2012, from http://www.nytimes.com/2012/06/30/opinion/stifled-dissent-in-rwanda.html Mashuli, E. (2011, December 9). Rwanda: Murder of Rwandan online journalist lights up the internet. Retrieved February 4, 2014, from 
http:/ /globalvoicesonline.org/2011/12/09/rwanda-murder-of-rwandan-online-journalistlights-up-the-internet/

Matsiko, H., \& Mwenda, A. (2014, January 10). Who killed Karegeya? Retrieved February 7, 2014, from http://www.independent.co.ug/cover-story/8594-who-killed-karegeya

McGreal, C. (2008, May 16). 'We have to kill Tutsis wherever they are' Retrieved October 30, 2012, from http://www.guardian.co.uk/world/2008/may/16/congo.rwanda

McGreal, C. (2013, May 19). Is Kagame Africa's Lincoln or a tyrant exploiting Rwanda's tragic history? Retrieved May 20, 2013, from http://www.guardian.co.uk/world/2013/may/19/kagame-africa-rwanda?guni=Network

Media High Council of Rwanda. (2013, April 18). Journalists killed during the genocide honored. Retrieved January 5, 2014, from http://www.mhc.gov.rw/news-details/article/journalistskilled-during-the-genocide-honored.html

Noorlander, P. (2010, August 9). How Paul Kagame has used the law to muzzle Rwanda's media. Retrieved April 7, 2013, from http://www.guardian.co.uk/law/2010/aug/09/rwandapaul-kagame-media-censorship

Noorlander, P. (2013, March 20). Rwandan media under attack despite new press laws. Retrieved March 29, 2013, from http://www.guardian.co.uk/world/2013/mar/20/rwandajournalists-attack-media?INTCMP=SRCH

Nyamwasa, K., Karegeya, P., Rudasingwa, T., \& Gahima, G. (2010, August). Rwanda briefing. Retrieved February 6, 2014, from http://greatlakesdemocracy.blogspot.ca/2010/09/rwanda-briefing-by-gen-kayumbanyamwasa.html 
Perry, A. (2012, September 14). Q\&A: Rwandan President Paul Kagame. Retrieved April 7, 2013, from http://world.time.com/2012/09/14/qa-rwandan-president-paul-kagame/

Power, S. (2001, September). Bystanders to genocide. Retrieved December 07, 2013, from http:/ /www.theatlantic.com/magazine/archive/2001/09/bystanders-togenocide $/ 304571 /$ ?single_page $=$ true

Reporters Without Borders. (2002, April 30). Rwanda: Annual report 2002. Retrieved February 5, 2014, from http://en.rsf.org/article.php3?id_article=1834

Reporters Without Borders. (2003). Rwanda - 2003 annual report. Retrieved February 5, 2014, from http:/ /archives.rsf.org/article.php3?id_article=6437

Reporters Without Borders. (2011, September 12). Rwanda. Retrieved March 13, 2013, from http:/ / en.rsf.org/rwanda-rwanda-07-01-2010,35948.html

Rhodes, T. (2012, December 11). Jailed Rwandan editors turn to African Commission. Retrieved February 2, 2013, from http://www.cpj.org/blog/2012/12/jailed-rwandan-editors-turnto-african-commission.php

Ritter, K. (2012, February 13). Sweden expels Rwandan diplomat. Retrieved February 20, 2014, from http://seattletimes.com/html/nationworld/2017496917_apeuswedendiplomatexpelled.ht $\mathrm{ml}$

Roth, K. (2009, April 11). The Power of Horror in Rwanda. Retrieved January 26, 2014, from http://www.hrw.org/en/news/2009/04/11/power-horror-rwanda

Sabbagh, D., \& O'Carroll, L. (2012, November 29). Leveson report calls for new press law. Retrieved February 17, 2014, from http://www.theguardian.com/media/2012/nov/29/leveson-report-new-press-law 
Sabbagh, D. (2012, November 28). Leveson inquiry: The essential guide. Retrieved February 15, 2014, from http://www.theguardian.com/media/2012/nov/28/leveson-inquiry-reportessential-guide

Smith, D. (2010, June 25). Editor blames security forces after Rwandan journalist shot dead. Retrieved February 6, 2014, from http://www.theguardian.com/world/2010/jun/25/rwandan-journalist-shot-dead

Smith, D. (2010, June 21). Former Rwandan army chief shot in South Africa. Retrieved February 6, 2014, from http://www.theguardian.com/world/2010/jun/21/rwandan-army-chiefshot-south-africa?guni=Article:in $\% 20$ body $\% 20$ link

Smith, D. (2012, October 18). Rwandan minister is leader of Congo rebels, UN says. Retrieved February 26, 2014, from http://www.theguardian.com/world/2012/oct/17/rwandaminister-leader-congo-rebels-kabarebe

Smith, D. (2012, October 10). Paul Kagame's Rwanda: African success story or authoritarian state? Retrieved October 20, 2012, from http://www.guardian.co.uk/world/2012/oct/10/paul-kagame-rwanda-successauthoritarian

Smith, D. (2014, March 20). Rwanda criticised over media harassment after hostile tweets exposed. Retrieved March 22, 2014, from http://www.theguardian.com/world/2014/mar/20/rwanda-media-harassment-hostiletweets?CMP=twt_gu

Terrill, S. (2012, April 4). A threat to the nation: Two Rwandan journalists. Retrieved November 28, 2012, from http://www.rnw.nl/africa/article/a-threat-nation-two-rwandan-journalists 
Terrill, S. (2012, April 6). Rwandan court reduces sentences on jailed journalists. Retrieved November 28, 2012, from http://www.globalpost.com/dispatch/news/regions/africa/120405/rwandan-courtreduces-sentences-jailed-journalists

Tertsakian, C. (2011, June 15). Murder or imprisonment: A high price for "stability" in Rwanda. Retrieved February 5, 2014, from http://www.hrw.org/news/2011/06/15/murder-orimprisonment-high-price-stability-rwanda

Thomson, S. (2014, March 17). Rwanda's Twitter-Gate: The disinformation campaign of Africa's digital president. Retrieved March 20, 2014, from http:/ / africanarguments.org/2014/03/17/rwandas-twitter-gate-the-disinformationcampaign-of-africas-digital-president-by-susan-thomson/

United Nations General Assembly. (1948, December 9). Convention on the prevention and punishment of the crime of genocide. Retrieved May 13, 2013, from http://www.hrweb.org/legal/genocide.html 